\title{
THE IMPACTS OF QUALITY MANAGEMENT PRACTICES ON INNOVATION
}

\section{DONG YOUNG KIM}

\author{
B.A., M.B.A.
}

A thesis submitted to the Faculty of Graduate Studies and Research in partial fulfillment of the requirements for the degree of

Doctor of Philosophy in Management

Sprott School of Business

Carleton University

Ottawa, Canada

May 2010 
Library and Archives

Canada

Published Heritage

Branch

395 Wellington Street Ottawa ON K1A ON4

Canada
Bibliothèque et

Archives Canada

Direction du

Patrimoine de l'édition

395, rue Wellington

Ottawa ON K1A ON4

Canada
Your file Votre reférence

ISBN: 978-0-494-67890-9

Ourfile Notre reférence

ISBN: $978-0-494-67890-9$
NOTICE:

The author has granted a nonexclusive license allowing Library and Archives Canada to reproduce, publish, archive, preserve, conserve, communicate to the public by telecommunication or on the Internet, loan, distribute and sell theses worldwide, for commercial or noncommercial purposes, in microform, paper, electronic and/or any other formats.

The author retains copyright ownership and moral rights in this thesis. Neither the thesis nor substantial extracts from it may be printed or otherwise reproduced without the author's permission.
AVIS:

L'auteur a accordé une licence non exclusive permettant à la Bibliothèque et Archives Canada de reproduire, publier, archiver, sauvegarder, conserver, transmettre au public par télécommunication ou par l'Internet, prêter, distribuer et vendre des thèses partout dans le monde, à des fins commerciales ou autres, sur support microforme, papier, électronique et/ou autres formats.

L'auteur conserve la propriété du droit d'auteur et des droits moraux qui protège cette thèse. $\mathrm{Ni}$ la thèse ni des extraits substantiels de celle-ci ne doivent être imprimés ou autrement reproduits sans son autorisation.
In compliance with the Canadian Privacy Act some supporting forms may have been removed from this thesis.

While these forms may be included in the document page count, their removal does not represent any loss of content from the thesis.
Conformément à la loi canadienne sur la protection de la vie privée, quelques formulaires secondaires ont été enlevés de cette thèse.

Bien que ces formulaires aient inclus dans la pagination, il n'y aura aucun contenu manquant. 


\section{Acknowledgements}

I am grateful to Dr. Vinod Kumar and Dr. Uma Kumar for their encouragement, support and invaluable advice during my Ph.D. program. I thank my committee members, Dr. Chhajju Bector, Dr. WonJoon Chung, Dr. Aaron Nsakanda, and Dr. Raili Pollanen for their constructive comments and suggestions. I am grateful to my colleagues for their continuous support. Finally, I thank DoYoun, Junho, and Munho for their sacrifice over the last four years. 


\begin{abstract}
Researchers have explored the relationship between quality management (QM) and innovation in a variety of ways. A review of the literature, however, shows a few research gaps in the existing studies. There is a relative dearth of empirical studies on the interrelationships among QM practices and how they affect innovation. Moreover, there is no consistency among previous studies on the contribution of QM to innovation. While some studies have found that QM practices are positively related to innovation, others have concluded that there is no evidence of such a link. Further, the empirical studies are limited to assessing only a few types of innovation and fail to test the interaction effects of contextual variables.
\end{abstract}

The purpose of this study is three-fold: to investigate the impact of QM practices on five different types of innovation, to explore the relationships between behavioural and mechanistic QM practices, and to test the interaction effects of contextual variables. Using structural equation modeling (SEM), the proposed framework and hypotheses based on a sample of 223 ISO 9001 certified companies in Canada were empirically tested. The results indicate that QM practices have either a direct or indirect effect on innovation. Behavioural QM practices, such as management leadership and training, are significantly related to mechanistic QM practices, such as process management and product design. On the other hand, there is no interaction effect of moderating variables in the relationship between QM and innovation. This research contributes to the literature in three ways: it enables academics and practitioners to understand how and why QM practices foster innovation, it provides empirical evidence about the ways behavioural QM practices are related to mechanistic $\mathrm{QM}$ practices, and it enhances the understanding of the contextual effects of moderating variables. 


\section{Table of Contents}

Acknowledgements ……............................................................................................................................................. i

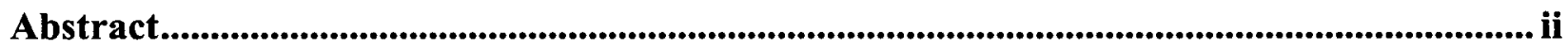

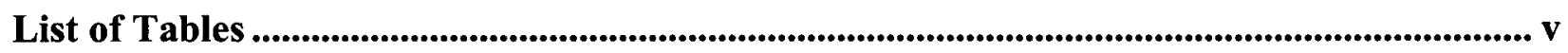

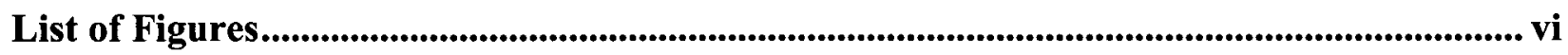

1. Research motivation and research objective ................................................................................ 1

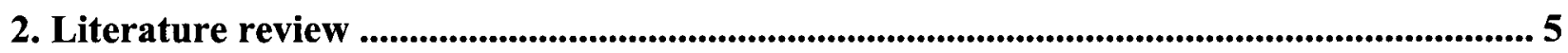

2.1. The evolution of study on QM practices ........................................................................ 5

2.2. Linkage-focused research on QM practices .................................................................. 9

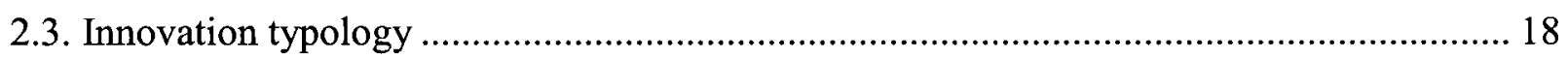

2.3.1. Technological versus administrative innovation ..................................................... 18

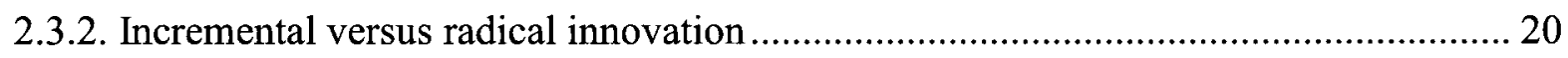

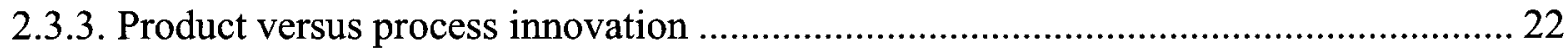

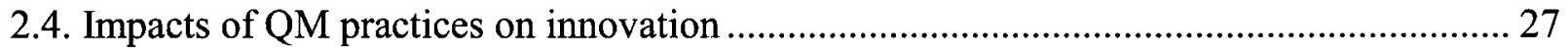

3. Theoretical framework and hypotheses......................................................................................... 38

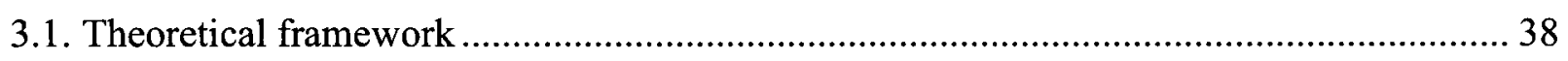

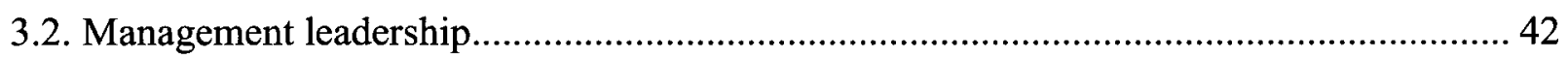

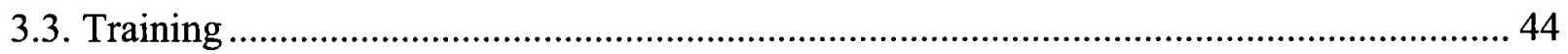

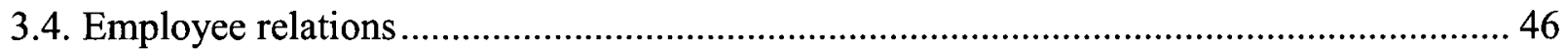

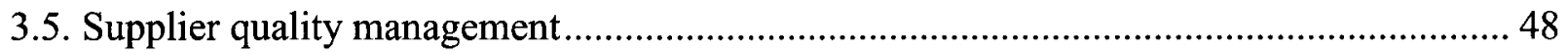

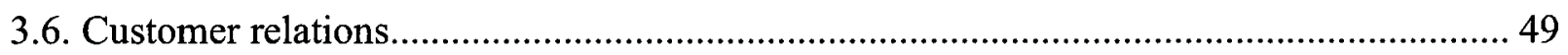

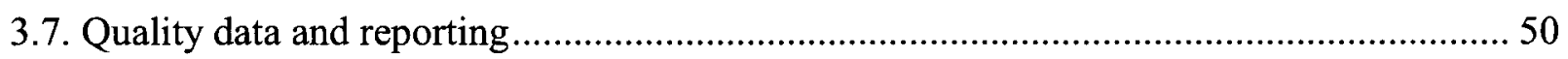

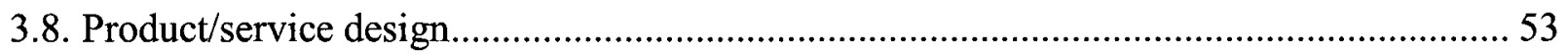

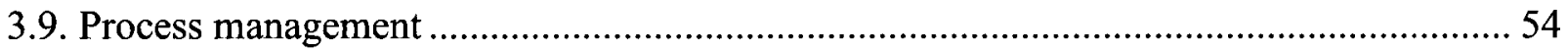


3.10. Behavioural practices versus mechanistic practices.......................................... 55

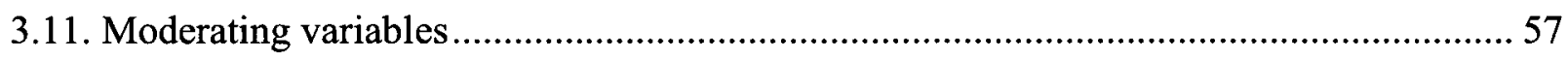

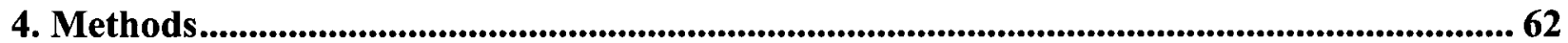

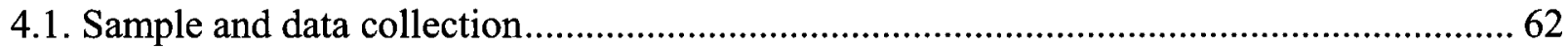

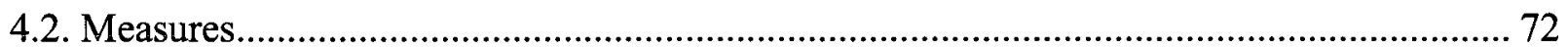

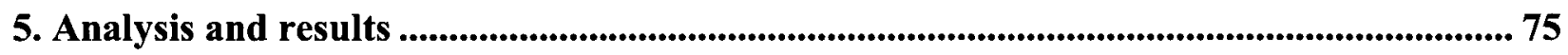

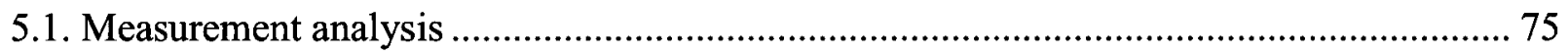

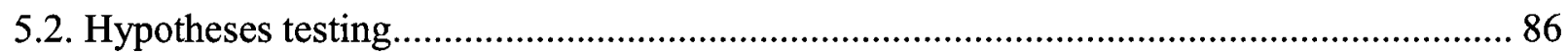

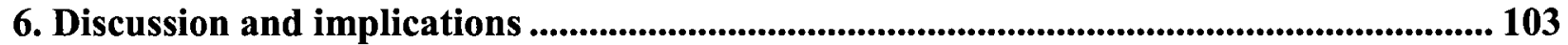

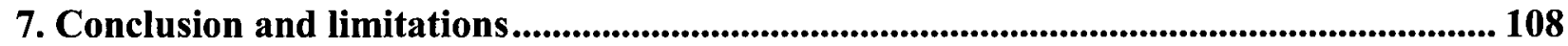

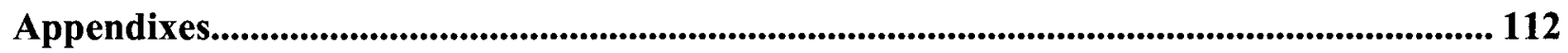

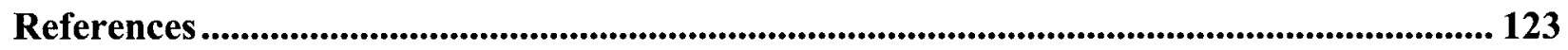

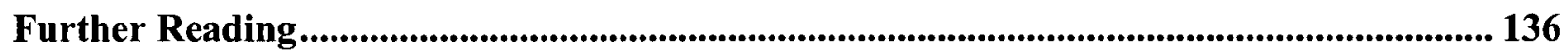




\section{List of Tables}

Table 1. Relationships among QM practices identified in empirical studies ........................... 14

Table 2. Comparison of radical, incremental, and administrative Innovations ......................... 25

Table 3. Empirical studies on the relationship between QM practices and innovation ............... 33

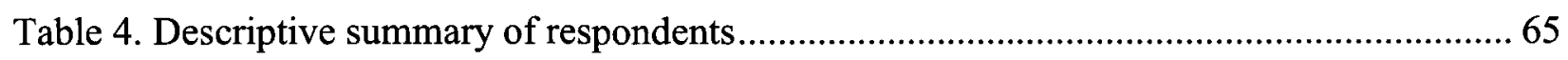

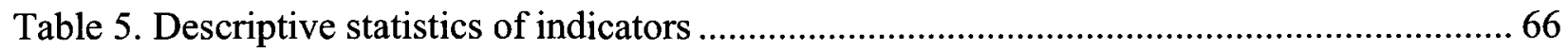

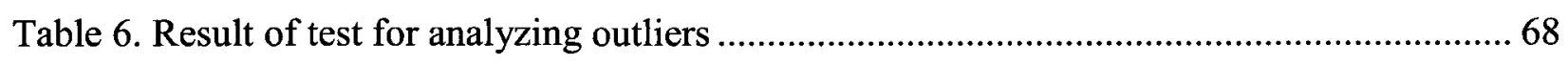

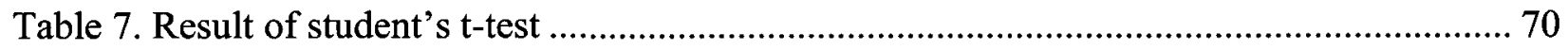

Table 8. Formulas to calculate composite reliability and average variance extracted................ 77

Table 9. Analysis results of the measurement models ........................................................ 79

Table 10. Factor loading, standardized loading, standard errors, and t-values........................8 82

Table 11. Discriminant validity assessment using a $\chi^{2}$ difference ....................................... 84

Table 12. Discriminant validity assessment using Cronbach's $\alpha$ and AVE ............................86

Table 13. Analysis results of the structural model .............................................................90

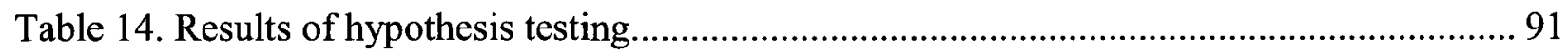

Table 15. Total effects and indirect effects.............................................................. 93

Table 16. Multi-group analysis result to test interaction effects of moderating variables......... 100 


\section{List of Figures}

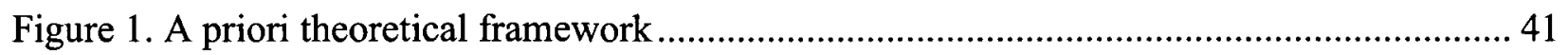

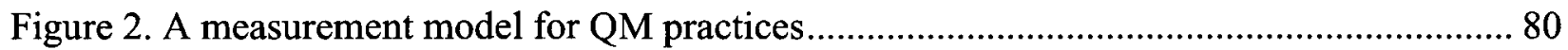

Figure 3. A measurement model for innovation .................................................................... 81

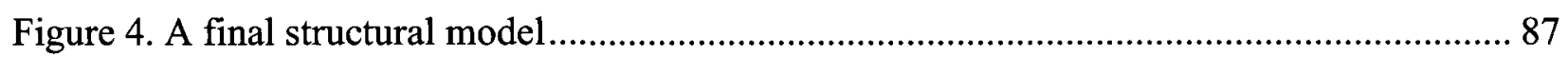

Figure 5. A structural model focusing on five paths................................................................... 98 


\section{Research motivation and research objective}

Over the past 30 years, innovation has caught the attention of researchers and practitioners (Gatignon et al., 2002; Damanpour, 1987). In a turbulent economic environment, innovation is a strategic driver to seize new opportunities and protect knowledge assets (Hurmelinna-Laukkanen et al., 2008; Moguilnaia et al., 2005; Teece, 2000). Specifically, innovation plays a key role in providing unique products/services, creating new values that were not recognized, and establishing entry barriers (Lloréns Montes et al., 2005). The value of innovation can also be explained by the increasing amount of expenditure for research and development (R\&D), which is one of the most representative innovation areas. According to the latest report of the Organisation for Economic Cooperation and Development (OECD), the total gross expenditure on R\&D in OECD countries increased annually by 4.9 per cent between 1995 and 2000; the real expenditure on R\&D grew substantially by more than 33 per cent between 1995 and 2004 (OECD, 2006).

The importance of innovation has motivated researchers to identify various driving forces of innovation, such as internal or contextual factors (Becheikh et al., 2006). Some researchers contends that quality management (QM) could be one of the prerequisites of innovation (Hoang et al., 2006; Perdomo-Ortiz et al., 2006). QM is broadly acknowledged to be a management model that is not only influencing operational and financial performance but also building competitive advantage (Kaynak, 2003). It is not surprising that many manufacturing and service firms around the world (e.g., Xerox, Ford, Motorola, and Federal Express) have adopted QM over the last two decades (Rahman, 2004; Powell, 1995). However, researchers still question 
whether QM leads to innovation (Prajogo and Sohal, 2001). Along this line, QM researchers concentrate on exploring links or interaction effects between innovation and QM practices, such as management leadership, training, and process management.

While previous studies have provided interesting insight into the role of QM practices in innovation, a few shortcomings emerge from the literature review. First, there is a lack of empirical study on the contribution of QM to innovation (Hoang et al., 2006; Martinez-Costa and Martinez-Lorente, 2008; Perdomo-Ortiz et al., 2006; Prajogo and Hong, 2008; Singh and Smith, 2004). The literature review shows that only a few empirical studies theorized the relationship between QM and innovation since the early 2000s (e.g., Singh and Smith, 2004). Most studies by the late 1990s tested their hypotheses using case studies or a conceptual approach. Further, little attention was paid to the interaction effects among QM practices that would yield innovation.

Second, earlier studies provided mixed results on the impacts of QM on innovation. Some found that QM practices are positively related to innovation (e.g., Perdomo-Ortiz et al., 2006; Martinez-Costa and Martinez-Lorente, 2008), whereas others concluded that there is no evidence linking QM activities and innovation (e.g., Singh and Smith, 2004; Moura E Sá and Abrunhosa, 2007; Prajogo and Sohal, 2004; Santos-Vijande and Álvarez-González, 2007). With respect to the identification of key QM practices, some researchers contended that only a few QM practices, but not nearly all QM practices, have a positive relationship with innovation (e.g., Perdomo-Ortiz et al., 2006). Others, however, found that all QM practices are positively related to innovation (e.g., Martinez-Costa and Martinez-Lorente, 2008). Along the same line, prior studies provided conflicting evidence on whether behavioural QM practices - e.g., leadership and employee relations - are more significantly associated with innovation than mechanistic QM practices - e.g., process management and quality data (Feng et al., 2006; Hoang et al., 2006). 
Third, prior empirical studies on the effects of QM were limited to assessing a few types of innovation. For instance, some discussed only a single type of innovation, such as product innovation (e.g., Prajogo and Sohal, 2004) or process innovation (Abrunhosa and Moura E Sá, 2008). Other studies dealt with only two types of innovation (product and process innovation). It can be argued that such a narrow view of innovation is a barrier that causes a misunderstanding of the impacts of $\mathrm{QM}$ on innovation. Little attempt was made to investigate the multidimensionality of the innovation construct that comprises radical, incremental, and administrative innovation. Therefore, a review of the previous studies gives rise to the following questions: How do QM practices link to innovation? How do behavioural practices influence mechanistic practices to result in innovation? Do QM practices have a significant impact on different types of innovation? Thus, this study concentrates on the research questions by conducting linkage-focused research on how QM practices influence various types of innovation. Along similar lines, the purposes of this study are:

1. To examine how QM practices impact five types of innovation: radical product, radical process, incremental product, incremental process, and administrative innovation.

2. To investigate the relationships between behavioural $Q M$ practices and mechanistic QM practices.

3. To test the interaction effects of moderating variables (firm size, the duration of QM adoption, structural control, structural exploration, and industry) on the relationship between QM practices and innovation. 
The remainder of this study is organized as follows. Section 2 examines the extant literature pertaining to QM practices, innovation typology, and the impacts of QM practices on innovation. Section 3 develops a theoretical framework and hypotheses. Section 4 presents methods, including data collection and measurement scales. Section 5 shows data analysis procedures and research findings. Finally, this study concludes with discussion, implications of the results, and directions for future research. 


\section{Literature review}

This section discusses four important topics: the evolution of study about QM practices, the linkage-focused research on QM practices, the innovation typology, and the impacts of QM practices on innovation.

\subsection{The evolution of study on $Q M$ practices}

Since the 1930s, QM has caught the attention of researchers and practitioners (Abrunhosa and Moura E Sá, 2008). Traditionally, researchers considered QM to be a simple inspectionoriented system highlighting quality control in a scientific and rigorous fashion (Flynn et al., 1994). In that period, quality activities mainly relied on results-oriented, narrow, and mechanistic approaches called "after the fact" control techniques (Mehra et al., 2001). For example, statistical process control was used as one of the most popular techniques to identify variation and quality in systems (Rahman, 2004). However, in 1950s and 1960s, practitioners recognized many limitations of the inspection-based perspective when making an effort to enhance customer satisfaction and core competencies in mass production (Hendricks and Singhal, 2001). Highly competitive markets began to require organizations to implement the comprehensive managerial principles underlining behavioural aspects (Hafeez et al., 2006).

To survive in the new paradigm, organizations changed the direction of $\mathrm{QM}$ from an inspection focus to a market-based orientation (Idris and Zairi, 2006). It was necessary for organizations to identify and improve the root causes of quality problems before delivering 
products or services to customers. To reflect the change, organizations paid attention to organization-wide philosophies, such as the involvement of all employees, customer relations, and a long-term improvement process (Mehra et al., 2001). In the early 1980s, QM technical methods and behavioural concepts were integrated and developed into a comprehensive management philosophy: TQM (Rahman, 2004). Many researchers seriously explored the implementation of TQM (Waldman, 1994). While previous researchers made efforts to gain clear insights into the implementation of QM, the majority of empirical studies on QM suffered from a narrow focus and a lack of rigor in terms of validity and reliability issues. In particular, the discussion of QM practices itself barely received any significant attention in empirical studies (Flynn et al., 1994). Researchers, however, recognized that examining QM practices is an essential and primary prerequisite to provide effective management and competitive survival (Nair, 2006). Along this line, since the late 1980s much attention has been devoted to developing the measurement constructs of QM and examining the net impacts of QM practices (Park et al., 2001; Ahire and Ravichandran, 2001).

Several researchers have conducted the development of measurement constructs on QM practices (Flynn et al., 1994). For example, Saraph et al. (1989) were the first to attempt to explore the measurement of QM practices (Perdomo-Ortiz et al., 2006). Their motivation fuelled due to a lack of a systematic attempt to organize a set of QM practices and develop measures of the overall QM efforts in the QM literature. Using a survey of 162 general managers and quality managers, they proposed eight critical factors of QM: the role of management leadership, the role of the quality department, training, employee relations, quality data and reporting, supplier quality management, product/service design, and process management. Similarly, Flynn et al. (1994) argued that QM studies on theory development and measurement failed to yield 
conclusive evidence related to validity and reliability. On the basis of a sample of 716 respondents at 42 plants in the United States, they suggested seven key dimensions of QM and scales: top management support, quality information systems, process management, product design, work force management, supplier involvement, and customer involvement. Ahire et al. (1996) responded to the lack of studies that scientifically examine constructs to measure the role of QM efforts. In a field study of 371 companies in the automotive components manufacturing industry, they identified $12 \mathrm{QM}$ constructs: top management commitment, customer focus, supplier quality management, design quality management, benchmarking, statistical process control usage, internal quality information usage, employee empowerment, employee involvement, employee training, product quality, and supplier performance.

Although there was no clear agreement on a list of QM practices (Samson and Terziovski, 1999), the efforts to develop a set of QM practices provided a theoretical foundation to scientifically connect traditional QM philosophies with practical activities. Researchers believed that the successful adoption of QM philosophies can be attributed to the strong support of a set of QM practices (Ravichandran, 2007; Nair, 2006). Similarly, the sets of QM practices discussed were broadly cited in the literature (e.g., Perdomo-Ortiz et al. 2006) and frequently used in replication studies (e.g., Kaynak, 2003). Adopting the methodology used in the previous studies, such as factor analysis, several other studies developed reliable measures (e.g., Samson and Terziovski, 1999). The QM practices were also used to develop criteria for several quality awards, such as the European Foundation for Quality Award (EFQA) and the Malcolm Baldrige National Quality Award (MBNQA) (Sousa and Voss, 2002).

Prior studies further extended the QM practices theory by questioning the extent to which QM practices are correlated with performance. Most empirical studies posited that organizational 
performance is accomplished by a set of QM practices (Douglas and Judge, 2001). They focused on examining the impacts of a set of QM practices (input) on performance (output). For example, these studies had the following research questions: Which practices have a direct and positive effect on the performance? Is a degree of implementation of QM practices positively related to the performance? A common finding was that QM practices have a significant and positive effect on operational and quality performance (Zaho et al., 2004). However, most of the studies examined either the impact of QM practices on quality performance or the impact of quality performance on operational/business performance (Sousa and Voss, 2002). In other words, researchers simply focused on testing the correlations of the relationships (Sila and Ebrahimpour, 2005). Although these studies provided insight into possible relationships between QM practices and performance, there were very few studies on theory exploring the interactions among QM practices and the outcomes of QM efforts (Ahire and Ravichandran, 2001; Kaynak, 2003).

The narrow approach to the link between QM practices and performance resulted in several mixed findings or questions of the implementation of QM. For example, some researchers found that the adoption of QM is not always beneficial for all types of organizations. They argued that the failure rate is estimated to be as high as about 60 per cent (Dooyoung et al., 1998). These findings were inconsistent with the argument of quality proponents that all QM practices can be universally applied to yield performance in all kinds of organizations, regardless of the organizational context (Zaho et al., 2004; Park et al., 2001; Ravichandran and Rai, 2000). Further, some empirical studies doubted the effectiveness of mechanistic QM practices (e.g., process management, information and analysis, and product design) on performance (Feng et al., 2006; Hoang et al., 2006). Researchers found that only behavioural QM practices (e.g., leadership, people management, and customer relations) are significantly and positively 
associated with performance (Samson and Terziovski, 1999; Powell, 1995). These mixed and unclear findings in the $\mathrm{QM}$ literature encouraged academics to pay attention to the interdependence of QM practices (Ahire and Ravichandran, 2001). Studies on the interactions among QM practices are called linkage-focused research in this study.

\subsection{Linkage-focused research on QM practices}

Linkage-focused research considers the interdependent nature of QM practices. The main objective of this study is to explain why implementing QM is not always sufficient to result in maximum benefits for every company (Kaynak, 2003). The linkage-focused research refers to a study exploring why and how QM practices are interrelated (Ahire and Ravichandran, 2001). Unlike previous studies based on simple analysis approaches (e.g., regression or correlation analyses), the linkage-focused research relies on sophisticated analysis techniques, such as a path analysis (e.g., Flynn et al., 1995) and a partial least square method (e.g., Ravichandran and Rai, 2000) using structural equation modeling. Unfortunately, the literature review indicates that there are a very small number of linkage-focused studies (Sila and Ebrahimpour, 2005). Table 1 summarizes the results of previous studies. The main issues of these studies can be divided into three points: (1) Organizational performance can be achieved through a combination of QM practices; (2) The positive impacts of behavioural QM practices on performance can be mediated by mechanistic QM practices; (3) QM practices can lead to quality, operational, and business results. 


\section{Organizational performance can be achieved through a combination of QM practices:}

QM researchers view an organization to be a system of interlocking processes. They pay attention to the systems and processes as a source of variation in organizational performance (Soltani et al., 2004). A common view is that competitive advantage can be realized only if organizations handle and manage a combination of a series of practices, not just a few practices separately (Schendel, 1994). This view is, however, not fully supported by some empirical studies. For instance, Powell (1995), in a study conducted on 54 firms in the United States, found that the key to QM performance does not lie in practices such as quality tools or techniques. This finding could lead to the interpretation that organizations do not need to adopt or manage all QM practices. Similarly, Motwani et al. (1994, p. 49), in a sample of 73 manufacturing companies, found that "it is not necessary for all the factors to be present to ensure the success of the total quality programme."

By examining the interaction effects among QM practices, the linkage-focused studies help to identify the reasons for these mixed findings. Although researchers have found different results about the linkages of QM practices, a common finding in the linkage-focused studies is that each QM practice plays its own role in yielding performance. For instance, Ahire and Ravichandran (2001), in a linkage-focused study of 407 plants in the automobile industry, argued that cherry-picking a few QM practices is unlikely to result in significant improvement. They suggested that organizations should implement QM in an integrated fashion including all QM practices. Kaynak (2003) contended that scholars keep in mind the feature of multidimensionality of the QM construct when designing research. These findings are consistent with Douglas and Judge (2001), who found that a reason for the failure of QM is not implementing all key practices. 


\section{The positive impacts of behavioural QM practices on performance can be mediated by}

mechanistic QM practices: The implementation of QM encompasses both mechanistic and behavioural practices (Abruhosa and Moura E Sá, 2008; Rahman, 2004). Earlier studies in the QM literature were rooted in mechanistic practices because the evolution of traditional QM was started from the control of processes and products (Bou and Beltran, 2005). The mechanistic practices - called hard, mechanic, or core practices - aim to ensure that products or services meet customer requirements (Lopez-Mielgo et al., 2009). The mechanistic practices are closely associated with the mechanical/technical/process aspects, such as process management, product/service design, quality data and reporting, benchmarking, and quality tools (Zaho et al., 2004; Hoang et al., 2006; Flynn et al., 1995; Spencer, 1994). However, with a global market facing rapid change and uncertainty, organizations realized the importance of behavioural practices in creating an environment to support mechanistic practices (Rahman, 2004; Flynn et al., 1995; Soltani et al., 2005). The behavioural practices - called soft, organic, or infrastructure practices - are related to behavioural aspects, such as leadership, training, customer relations, workforce management, supplier quality management, and teamwork (Soltani et al., 2008; Rahman, 2004).

From a traditional viewpoint, some argued the necessity of the integrated impact of both aspects (e.g., Feng et al., 2006), while others reported on the importance of only one single aspect: either behavioural practices or mechanistic practices (e.g., Samson and Terziovski, 1999; Perdomo-Ortiz et al., 2006). On this issue, the linkage focused research attempted to explain how behavioural practices interact with mechanistic practices. One finding in the linkage-focused studies is that the mechanistic practices can mediate the effects of the behavioural practices on performance under a QM umbrella (Sousa and Voss, 2002). For example, Zu et al. (2008), in an 
empirical study of 226 U.S. manufacturing plants, examined the relationships among behavioural practices, mechanistic practices, and performance. They found that the behavioural practices have an impact on performance through the mechanistic practices. They also proved that there are significant and positive relationships between the behavioural and mechanistic practices, such as between workforce management and product/service design. Similarly, Flynn et al. (1995), in an empirical study based on a survey of 42 manufacturing plants in the United States, concluded that many behavioural practices are significantly related to mechanistic practices by providing significant paths, such as between top management support and product design process and between work attitude and process flow management.

QM practices can lead to quality, operational, and business results: In the linkagefocused studies, researchers concentrate on examining operational and financial performance. The approach is consistent with majority view of performance in the QM literature that classifies organizational performance into three streams: quality, operational, and business performance (Zaho et al., 2004; Park et al., 2001). For example, some linkage-focused studies tested the relationship between QM practices and a single performance, such as quality performance (e.g., Ravichandran and Rai, 2000; Ahire and Ravichandran, 2001) or customer satisfaction (e.g., Anderson et al., 1995; Rungtusanatham et al., 1998). Others examined multiple performances, such as operational and financial performance (e.g., Kaynak, 2003; Sila and Ebrahimpour, 2005; Zu et al., 2008; Flynn et al., 1995). Existent studies generally agree that QM practices improve quality and the operational and business performance. Further, linkage-focused researchers found that a few QM practices (e.g., process management and product/service design) positively and directly influence performance. For instance, Flynn et al. (1995) concluded that two practices the product design process and process flow management - directly influence quality 
performance. Similarly, Ravichandran and Rai (2000) found that one practice - process management efficacy - makes a direct impact on quality performance. Kaynak (2003) also proved that three practices - product/service design, process management, and supplier quality management - have direct impacts on inventory and quality performance.

In sum, the linkage-focused studies contribute to the development of QM theories by identifying what interactions among QM practices are crucial and which QM practices influence performance directly or indirectly. However, reviewing the linkage-focused studies gives rise to a question: What other performance through the implementation of QM should be evaluated? It can be argued that the impacts of QM practices can be available not only in operational performance but also in innovation. There is little attention paid to the relationships between QM practices and innovation in the linkage-focused study. This narrow view of the impacts of QM practices is one of the main obstacles that hinders the expansion of research scopes into QM practices. The lack of theories of a link between innovation and QM also limits our understanding of how quality-oriented organizations can survive in an innovation intensive environment. 


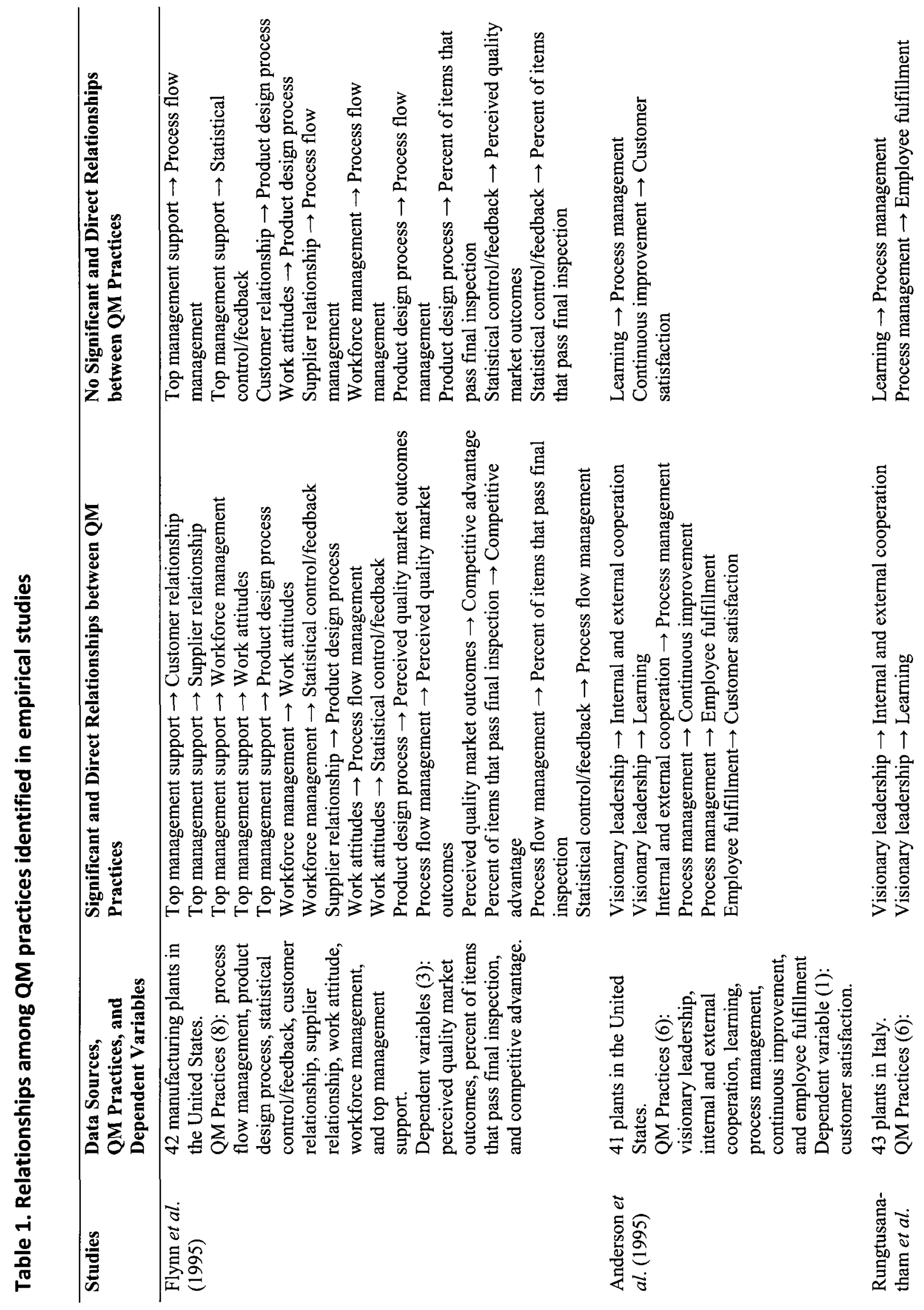




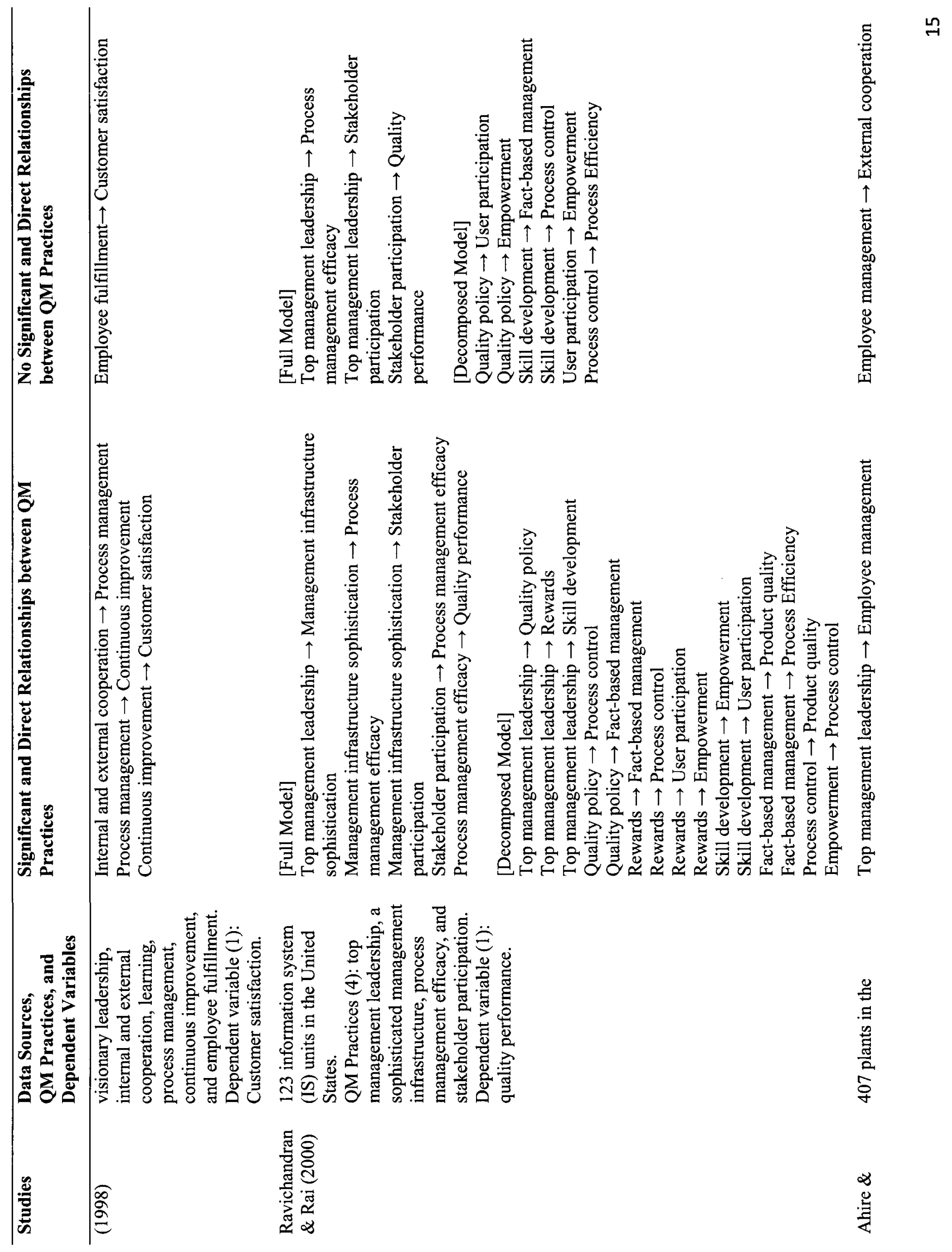




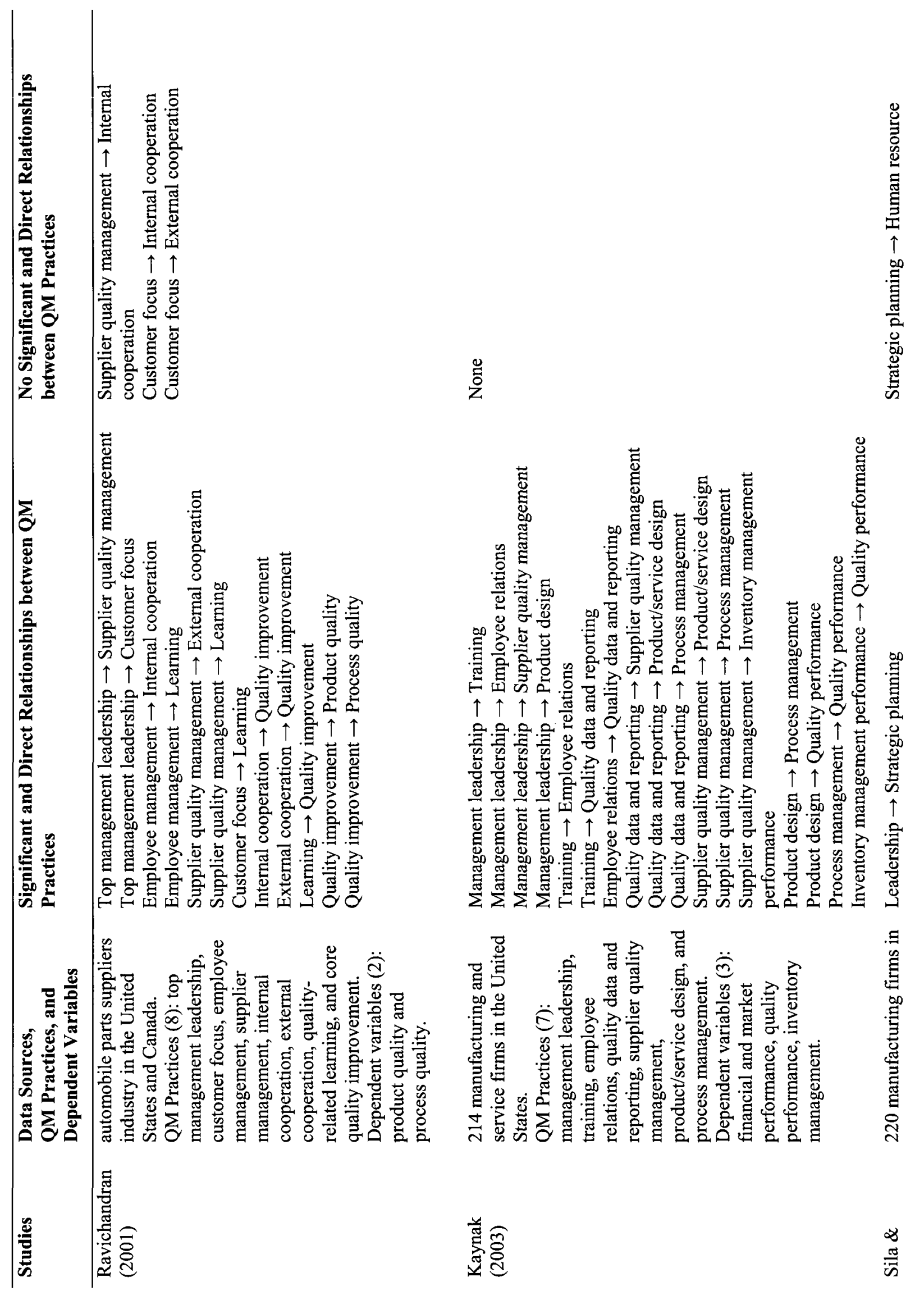




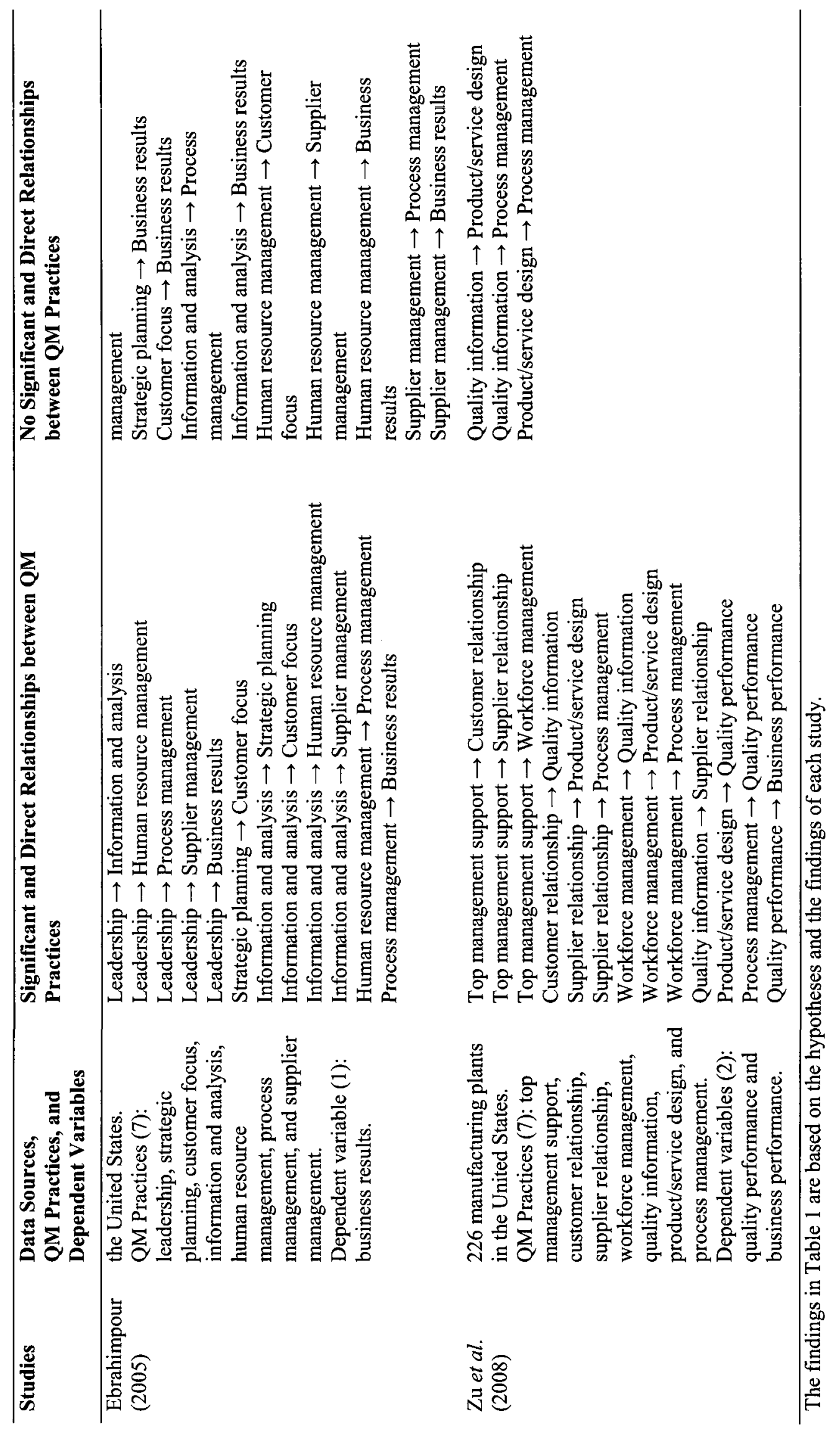




\subsection{Innovation typology}

It is essential to understand the types of innovation and their features because a specific type of innovation requires unique and sophisticated responses from an organization (Hurmelinna-Laukkanen et al., 2008). Researchers have developed a typology of innovation in different ways. In the innovation literature, there is either a similar name used for different innovations or the same innovation categorized into different typologies (Garcia and Calantone, 2002). Although previous innovation studies suggested several typologies of innovations, the most prominent type of innovation comprises the following categories: technological versus administrative innovation, incremental versus radical innovation, and product versus process innovation (Cooper, 1998; Zhao, 2005).

\subsubsection{Technological versus administrative innovation}

Technological innovation is defined as the adoption of new technologies that are integrated into products or processes (Yonghong et al., 2005; Cooper, 1998). Previous studies suggested that technological innovation provides organizations with competitiveness and long-

term success in a competitive marketplace (Grover et al., 2007; Leifer et al., 2001; Moors and Vergragt, 2002). Technological innovation is associated with the implementation of technologies to create new markets or to provide new features or functions, not just to solve a technological problem (Green et al., 1995). Technological innovations take place in products and services, while administrative innovations occur in organizational structures and include reward systems, authority patterns, and decision-making processes (Sabet and Klingner, 1993). Using a bottom- 
up approach, lower level R\&D professionals or technicians are involved in the development of technological innovation (Daft, 1978). The professionals rely on the use of a new tool, device, techniques, or system (Damanpour, 1987). Technological innovations are protected by intellectual property laws, such as patents (Hoffmann and Hegarty, 1993).

Administrative innovation, in contrast, refers to the application of new ideas to improve organizational structures, routines, systems, and processes pertaining to the social structure of an organization (Weerawardena, 2003; Loh and Venkatraman, 1992; Damanpour, 1987; Elenkov et al., 2005; Daft, 1978). Administrative innovation requires considerable set-up costs and entails organizational disruption. This is due to the fact that administrative innovation tends to call for major reassignment of responsibilities and tasks (Teece, 1980). Administrative innovation is triggered by internal needs for structuring and coordination, while technological innovation responds to environmental factors, such as uncertain market conditions or technical knowledge (Gaertner et al., 1984; Daft, 1978). Using a top-down approach, upper-level managers or administrators commit to relevant activities of administrative innovation (Daft, 1978; Ibarra, 1993). Administrative innovation influences basic work activities directly and customers indirectly (Weerawardena, 2003). Administrative innovation is diffused by a specialized agency, such as a consulting firm (Teece, 1980). The literature review, however, indicates that existing innovation studies are biased toward technological innovation (Prajogo and Sohal, 2006; Weerawardena, 2003). There is a lack of research about administrative innovation. Consistent with the views of Claver et al. (1998), it can be argued that technological innovation is not always sufficient to meet customer needs and maintain organizational competitiveness in a new global market. It is necessary to explore ways that technological and administrative innovations lead to a competitive advantage (Abrunhosa and Moura E Sá, 2008; Weerawardena, 2003). 


\subsubsection{Incremental versus radical innovation}

For almost 30 years, it has widely been recognized that technological innovation can be split into incremental innovation and radical innovation (Hurmelinna-Laukkanen et al., 2008; Grover et al., 2007; Salavou and Lioukas, 2003; Koberg et al., 2003; Green et al., 1995; Baker and Sinkula, 2007; Broring and Herzog, 2008; Pandey and Sharma, 2009). Both innovations are mutually exclusive, so the less chance for incremental innovation, the more chance for radical innovation (Salavou and Lioukas, 2003). Depending on the degree of innovation, researchers generally distinguish incremental innovation from radical innovation (Weerawardena, 2003). To

be more specific, incremental and radical innovations can be distinguished in terms of three key features: a target customer or market (existing vs. new), the level of change (minor vs. major), and the level of risk (low vs. high).

Incremental innovation is defined as minor changes of existing technologies in terms of design, function, price, quantity, and feature (Chandy and Tellis, 1998; Garcia and Calantone, 2002; De Propris, 2002). Incremental innovation aims to meet the needs of existing customers by refining, broadening, enhancing, and exploiting the current knowledge, skills, and technical trajectory (Gatignon et al., 2002; Broring and Herzog, 2008; Li et al., 2008; Jansen et al., 2006). In a technologically mature market, it is important to manage incremental innovation because continuous improvement of existing technologies helps to identify threats and opportunities related to the shift to a new technology paradigm (Garcia and Calantone, 2002). Lower-level technicians and R\&D workers achieve incremental innovation at all stages of a production life cycle (Daft, 1978; Garcia and Calantone, 2002; Ibarra, 1993). Incremental innovation entails a 
low level of risk because an organization focuses on modifying or improving existing technologies around radical innovation, not on breaking through an established technology trajectory or direction (Yonghong et al., 2005; Hurmelinna-Laukkanen et al., 2008; Valle and Vázquez-Bustelo, 2009). Less risk taking tends to accompany fewer benefits (Koberg et al., 2003).

Proponents of radical innovation, however, doubt the impacts of incremental innovation. They argue that incremental innovation is no longer enough in an intensified, competitive market. Instead, they view radical innovation as a core component in achieving sustainability goals (Moors and Vergragt, 2002). Radical innovation refers to the adoption of new technologies to create a demand unrecognized by customers and markets (Jansen, et al., 2006; Yonghong, et al., 2005; Garcia and Calantone, 2002). Radical innovation is likely to be triggered by market pull or technology push strategies (Li et al., 2008; Moguilnaia et al., 2005). For example, radical innovation provides either an unprecedented feature or a familiar feature that significantly disrupts a trajectory of existing technologies (Leifer et al., 2001). Radical innovation is regarded as competence-destroying because the innovation primarily changes the functions of existing technologies (Teece et al., 1997; Broring and Herzog, 2008). Using a bottom-up approach, lower-level technicians and R\&D workers accomplish radical innovation (Daft, 1978). Radical innovation entails great uncertainty and a high level of risk (Moguilnaia et al., 2005). The main reason for this is that there are many technical/market uncertainties, a high degree of complexity, and major changes in the existing technologies (Di Benedetto et al., 2008; HurmelinnaLaukkanen et al., 2008; Green et al., 1995; Valle and Vázquez-Bustelo, 2009). In this aspect, one study found that radical innovation covers only 10 per cent of all new innovations, whereas the proportion of incremental innovation is about 90 per cent (Rothwell and Gardiner, 1988). 


\subsubsection{Product versus process innovation}

Technological innovation comprises product innovation and process innovation (Damanpour, 1987). Product innovation refers to changes at the end of providing products or services, while process innovation is defined as changes in the way of producing products or services (De Propris, 2002; Utterback, 1994). The objective of product innovation is to meet the needs of customers or the external market. Product innovation is driven by either technological progress or market demand (Salavou and Lioukas, 2003). Product innovation is based on two dimensions: the technological capability dimension and the product capability dimension. The technological capability dimension represents the degree to which the product includes expanding technological capabilities beyond existing capabilities, while the product capability dimension is related to the benefits of products that customers perceive (Veryzer, 1998). Depending on the level of organizational capability at each dimension, product innovation could provide organizations with opportunities to create a new market or to change the balance of power in a competitive market (Herrmann et al., 2007). In terms of the degree of innovation, product innovation can be split into radical product innovation and incremental product innovation (Reichstein and Salter, 2006; Huiban and Bouhsina, 1998). Radical product innovation refers to innovation associated with the introduction of products (or services) that incorporate substantially different technology from existing products, whereas incremental product innovation is defined as innovation related to the introduction of products (or services) that provide new features, improvements, or benefits to the existing technology in the existing market (Herrmann, et al., 2007; Chandy and Tellis, 1998; Valle and Vázquez-Bustelo, 2009). 
Process innovation is described as changes in the way that an organization produces products or services (Koberg et al., 2003; Utterback, 1994). Process innovation is associated with the sequences and nature of the production process (De Propris, 2002). The main purpose of process innovation is to introduce a new element in production materials, machinery, equipment, processes, task specifications, and workflow mechanisms (Damanpour, 1991; Knight, 1967). Examples of process innovation include the implementation of automatic noodle making machines, the introduction of bulk packaging of sleeved products, the introduction of threedimensional modeling for design, an e-commerce site for sales and services, and the introduction of lean production systems (Reichstein and Salter, 2006). Along this line, process innovation tends to occur more often in large and bureaucratic firms than in small firms. This is because a large firm deals with many input materials and complicated processes with higher economic and social costs (Cooper, 1998). Unlike product innovation, process innovation focuses on improving the productivity and the efficiency of the production activities (Garcia and Calantone, 2002). Process innovation enables organizations to produce large amounts of products or services with limited resources or with higher performance levels (Abrunhosa and Moura E Sá, 2008). Moreover, process innovation can be achieved by a quality-based management approach, namely TQM. This happens because one of the main goals of TQM is to increase productivity and product quality through continual process improvement (Martinez-Costa and Martinez-Lorente, 2008). This argument is supported by prior empirical studies. For example, using data obtained from footwear manufacturing firms, Abrunhosa and Moura E Sá (2008) concluded that quality management practices (e.g., communication, teamwork, and supportive people management practices) have a positive and direct impact on process innovation. In terms of the degree of innovation, process innovation is generally classified into two types: incremental process 
innovation and radical process innovation (Reichstein and Salter, 2006, p. 656). Radical process innovation refers to innovation associated with the application of new or significantly improved elements into an organization's production or service operations - input materials, equipment, and work and information flow mechanisms - with the purpose of accomplishing lower costs and/or higher product quality. In contrast, incremental process innovation is identified as innovation associated with the application of minor or incrementally improved elements into an organization's production or service operations - input materials, equipment, and work and information flow mechanisms - with the purpose of accomplishing lower costs and/or higher product quality (Reichstein and Salter, 2006; Huergo and Jaumandreu, 2004; Ettlie, 1983; Gatignon et al., 2002).

In sum, innovation is categorized into technological versus administrative innovation, radical versus incremental innovation, and product versus process innovation. It is vital to understand the different objectives and features of each kind of innovation because a different type of innovation requires different activities and resources from an organization. Table 2 summarizes the key dimensions about the different types of innovation. 


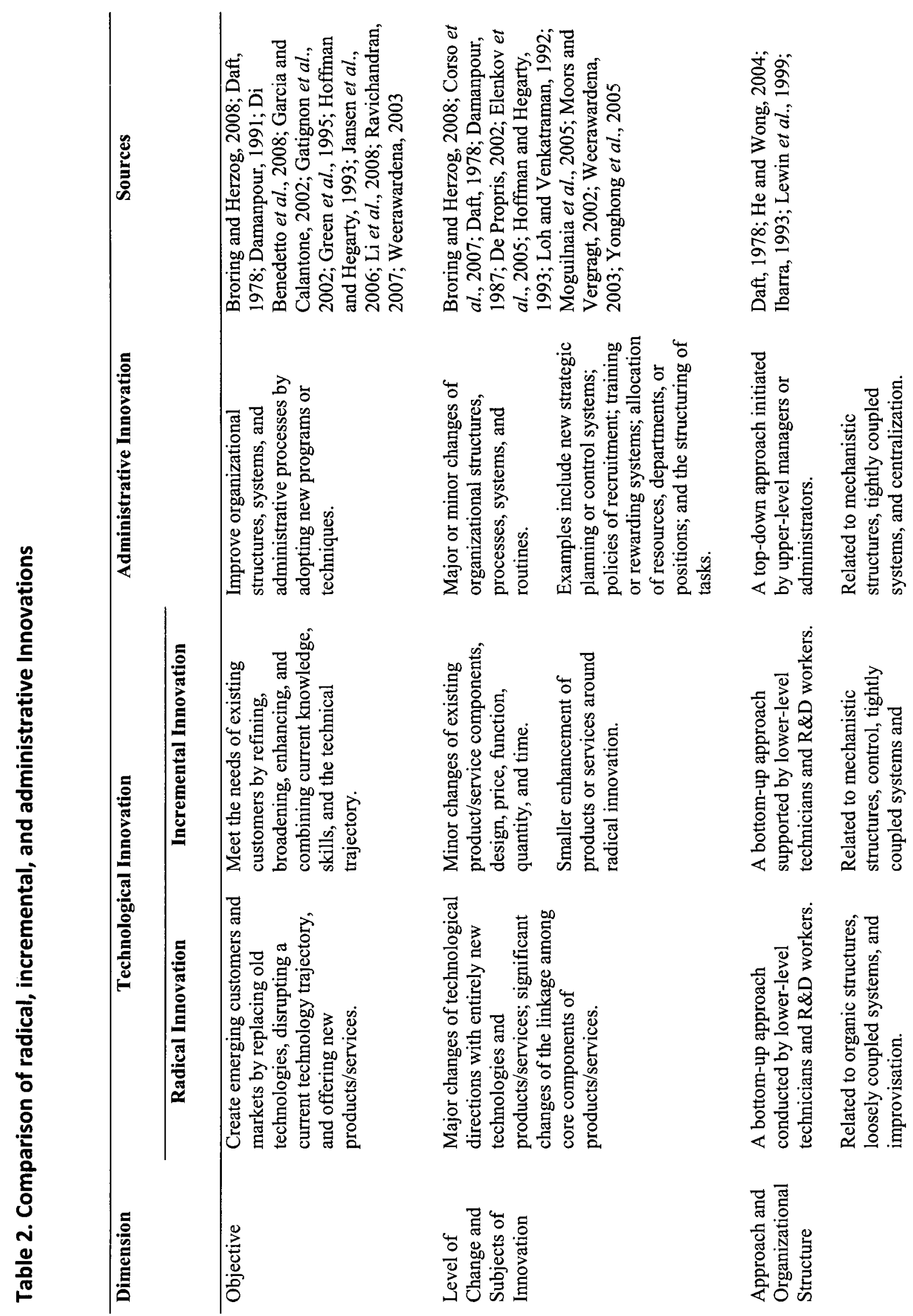




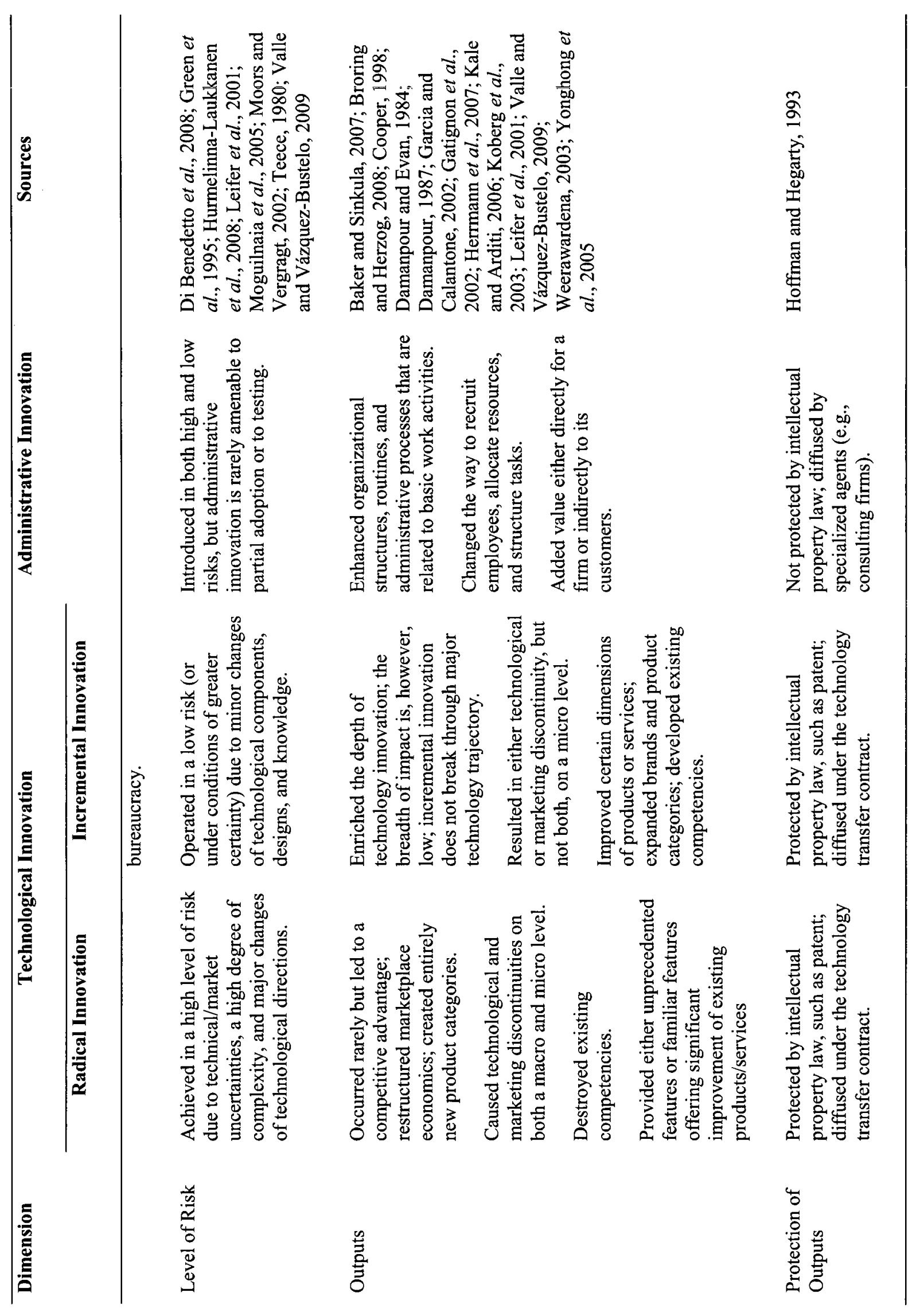




\subsection{Impacts of $Q M$ practices on innovation}

In a rapidly changing environment, high quality is necessary but not sufficient to guarantee success because of the impacts of other features, such as speed, price, and variety (Reimann and Hertz, 1994). The foundation of sustainable competition shifted from quality to innovation (Abrunhosa and Moura E Sá, 2008). Innovation plays a key role in meeting the needs of existing customers or creating a new product or service for emerging customers (Benner and Tushman, 2003). Innovation should be viewed as a core engine to strengthen the extra features and ensure long-term firm success (Leifer et al., 2001). At the organizational level, innovation refers to "the implementation of an internally generated or a borrowed idea - whether pertaining to a product, device, system, process, policy, program, or service - that was new to the organization at the time of adoption" (Damanpour and Evan, 1984, p. 393).

While innovation scholars conceptualized innovation from a variety of perspectives, a large body of studies has been involved in identifying internal determinants of innovation since the late 1960s (Souitaris, 2002). A literature review indicates that internal determinants are related to aspects of behaviour (e.g., leadership) and systems (e.g., control activity). For example, Becheikh et al. (2006), in a review study of 108 empirical studies published between 1993 and 2003, concluded that the internal determinants of innovation can be grouped into seven main categories: leadership and management team, organizational strategies, culture, firm structure, control activities, functional assets and strategies, and general characteristics of firms. Similarly, Pandey and Sharma (2009) argued that innovation is affected by a variety of factors, such as people, top management leadership, organizational structure, and culture. 
From a positive perspective, QM scholars argue that the internal determinants of innovation are significantly related to a set of QM practices (Perdomo-Ortiz et al., 2006). Behavioural QM practices, for example, could support some determinants of innovation - such as leadership, strategies, and culture - whereas mechanistic QM practices could influence control activities and functional assets and strategies. Similarly, QM scholars considered QM to be a management model for managing innovation (Prajogo and Sohal, 2001). QM researchers assert that examining the relationship between QM and innovation helps employees develop a better understanding of the roles of managerial practices in innovative environments (Prajogo and Sohal, 2001). For instance, as a sequential approach, organizations first identify customer needs based on QM techniques (e.g., the quality function deployment and value stream map) and then produce innovative products or services faster than competitors. Then the organizations standardize relevant processes or systems using QM-based models, such as the ISO 9001 quality management system (Lopez-Mielgo et al., 2009).

From the negative perspective, there is an ongoing debate over the effectiveness of QM on innovation in the context of an uncertain business environment. The main argument is that it is difficult to implement QM in an innovative organization. Studies explain reasons for this argument with two criteria: QM principles (e.g., customer relations) and features of innovative activities (e.g., an empirical science). In terms of QM principles, implementing QM is not appropriate in innovative activities (Prajogo and Sohal, 2001; Perdomo-Oritiz et al., 2006). This is because QM could lead organizations to delay innovation due to the principle of continuous improvement and to be reactive on a short-term basis due to the principle of customer focus. QM also hampers creativity due to the enforcement of formalizations or standards, which leads companies to be imitators or followers rather than innovators or leaders. 
With regards to the features of innovative activities, studies conclude that QM does not interact with innovation because innovative activities (e.g., R\&D) are different from other activities, such as production or marketing. Montana (1992), for example, suggested three reasons why it is hard to adopt QM in an innovative organization: $\mathrm{QM}$ is an experience-oriented model, not an empirical science; technicians or R\&D professionals define quality as perfection, not as simply conforming to customer expectations; and quality-based measures are not objective when measuring the performance of quality improvement within R\&D. Similarly, May and Pearson (1993) found that innovation is based on individuals, not a quality system; innovative activities are non-repetitive processes; and the cost of quality is not an appropriate measure when evaluating innovation. Vermaercke (2000) noted the following reasons that QM does not interact with innovation: the concept of a customer is vague in innovative efforts; $R \& D$ professionals tend to depend on their memory, not a written document; the objectives of an R\&D project may change during the process; and $\mathrm{R} \& \mathrm{D}$ professionals believe that customers are not always expert in their field. Unfortunately, by the end of the 1990s, most studies on the impacts of QM on innovation relied on conceptual or case studies (e.g., Lamb and Dale, 1994; Patino, 1997; Debackere et al., 1997; Lovett, 1992). Only a few empirical studies investigated a simple research question: Which QM practice is frequently used in innovative firms (e.g., Miller, 1994; Dellana and Wiebe, 1995)? These studies also made little effort to consider the multidimensionality of QM practices and innovation.

Since the early 2000s, researchers have conducted a limited number of empirical studies on the link between QM and innovation. As Table 3 shows, earlier studies adapted multidimensional constructs to measure organizational QM activities. Most studies used the measurement instrument developed by prior researchers (e.g., Flynn et al., 1994) or criteria of 
quality awards, such as the MBNQA and the EFQM awards. Only a few researchers developed their own set of QM practices based on the literature (e.g., Abrunhosa and Moura E Sá, 2008). In terms of the analytical framework, researchers applied a sophisticated analytical framework, such as structural equation modeling (e.g., Feng et al., 2006; Hoang et al., 2006; Prajogo and Sohal, 2004). Only a few researchers used a multiple regression or correlation analysis (e.g., Perdomo-Ortiz et al., 2006; Moura E Sá and Abrunhosa, 2007).

With respect to research findings, existing empirical studies yielded inconsistent results on the effect of QM on innovation. Some studies found that the adoption of QM is positively associated with innovation (Hoang et al., 2006; Martinez-Costa and Martinez-Lorente, 2008), while other studies reported that there is no clear evidence to statistically prove the positive effects of QM on innovation (Prajogo and Sohal, 2004; Singh and Smith, 2004). Furthermore, earlier studies produced different arguments on which QM practice plays a more important role in creating innovation. Some studies argued that only behavioural QM practices - leadership and people management - are closely associated with innovation (e.g., Feng et al., 2006). Others found that not all, but both behavioural and mechanistic QM practices - leadership, people management, process management, and product design - have a positive and direct relationship to innovation (e.g., Hoang et al., 2006; Perdomo-Ortiz et al., 2006). Overall, the literature review indicates that there is a lack of consistent evidence on the impact of QM practices on innovative environments.

This research identifies a few shortcomings of the earlier studies. A major shortcoming is that earlier studies failed to explore how and why a QM practice has an effect on innovation. Most studies examined only the direct relationships between QM practices and innovation. Researchers tend to identify whether the implementation of QM practices has a positive impact 
on innovation (e.g., Abrunhosa and Moura E Sá, 2008; Martinez-Costa and Martinez-Lorente, 2008; Hoang et al., 2006) or which QM practice is related to innovation (Moura E Sá and Abrunhosa, 2007; Prajogo and Sohal, 2004). There was little study to test how different QM practices are linked directly or indirectly and why the QM practices consequently influence innovation. Earlier studies answered only "what to do" rather than "how to do." Little attention was paid to the use of path analysis to analyze interaction effects among QM practices. It can be argued that developing a theory could be accomplished only if a researcher can provide answers about both what to do and how to do it.

Another shortcoming is that researchers were limited to assessing only a few types of innovation. Some studies examined a single type of innovation, such as process innovation (e.g., Abrunhosa and Moura E Sá, 2008) or product innovation (e.g., Prajogo and Sohal, 2004), whereas others explored both process and product innovation (e.g., Feng et al., 2006; MartinezCosta and Martinez-Lorente, 2008). Looking at the earlier studies, two questions arise: Is it worthwhile to examine QM practices that can influence only product and process innovations? If not, what other types of innovation should be explored to clearly address the impacts of QM on innovation? Limited attention was devoted to identifying and examining various types of innovation. However, testing the multidimensional types of innovation can contribute to the literature by providing a holistic insight into the real impacts of QM on innovation. Therefore, this study deals with the relationship between QM practices and the following dimensions of innovation discussed mainly in the innovation literature: technological vs. administrative, radical vs. incremental, and product vs. process (Zhao, 2005; Santos-Vijande and Álvarez-González, 2007). 
To summarize, the relationship between QM and innovation has been empirically investigated since the early 2000s. While researchers made efforts to develop theories from different perspectives, earlier studies failed to examine not only interactions among QM practices but also various types of innovation. Little attempt was made to answer how and why QM practices influence innovation. Most studies examined only narrow aspects of innovation, namely product or process innovation. The lack of theory development on the issue limits our understanding of how QM practices consistently lead to innovation. 


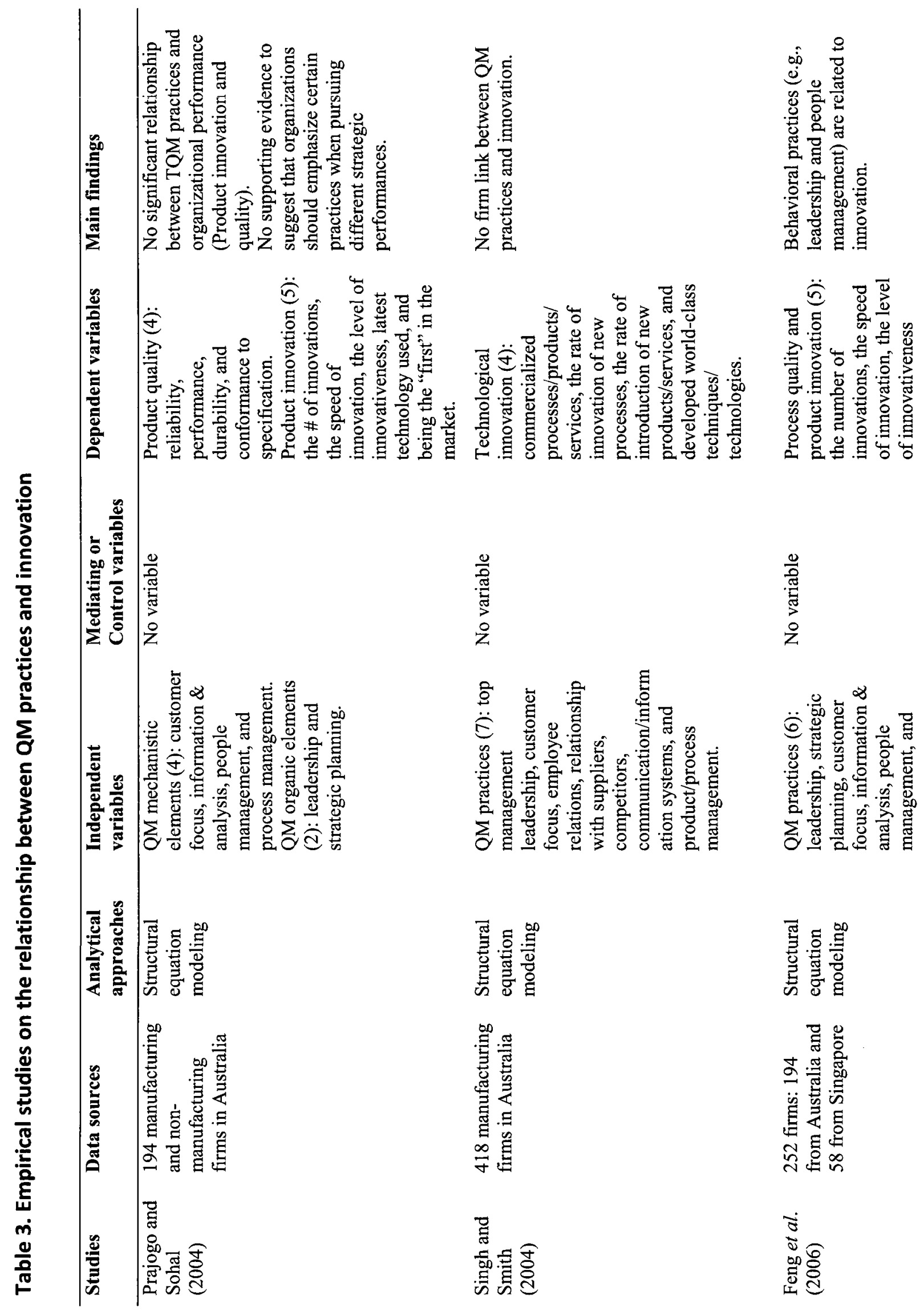




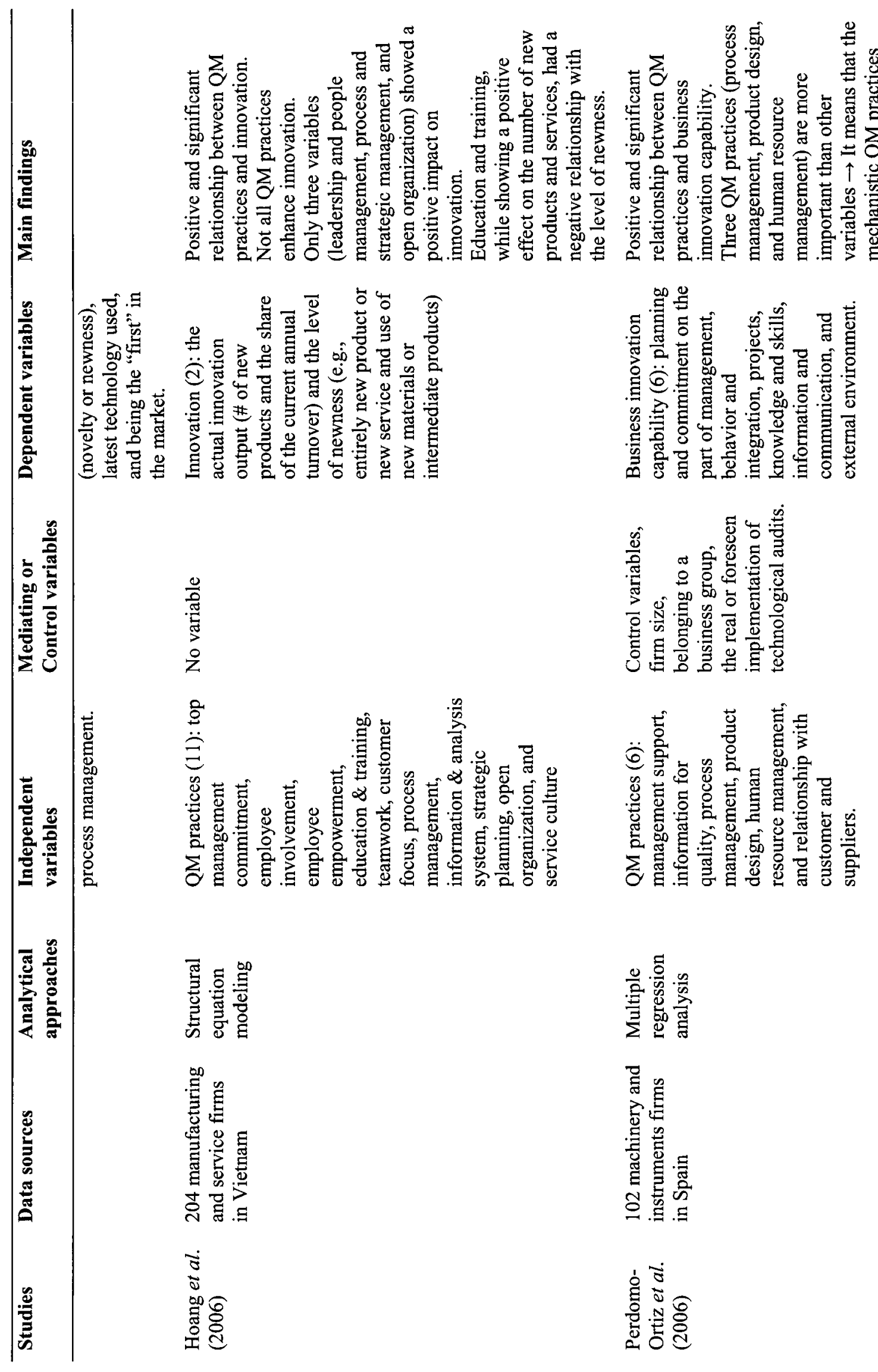




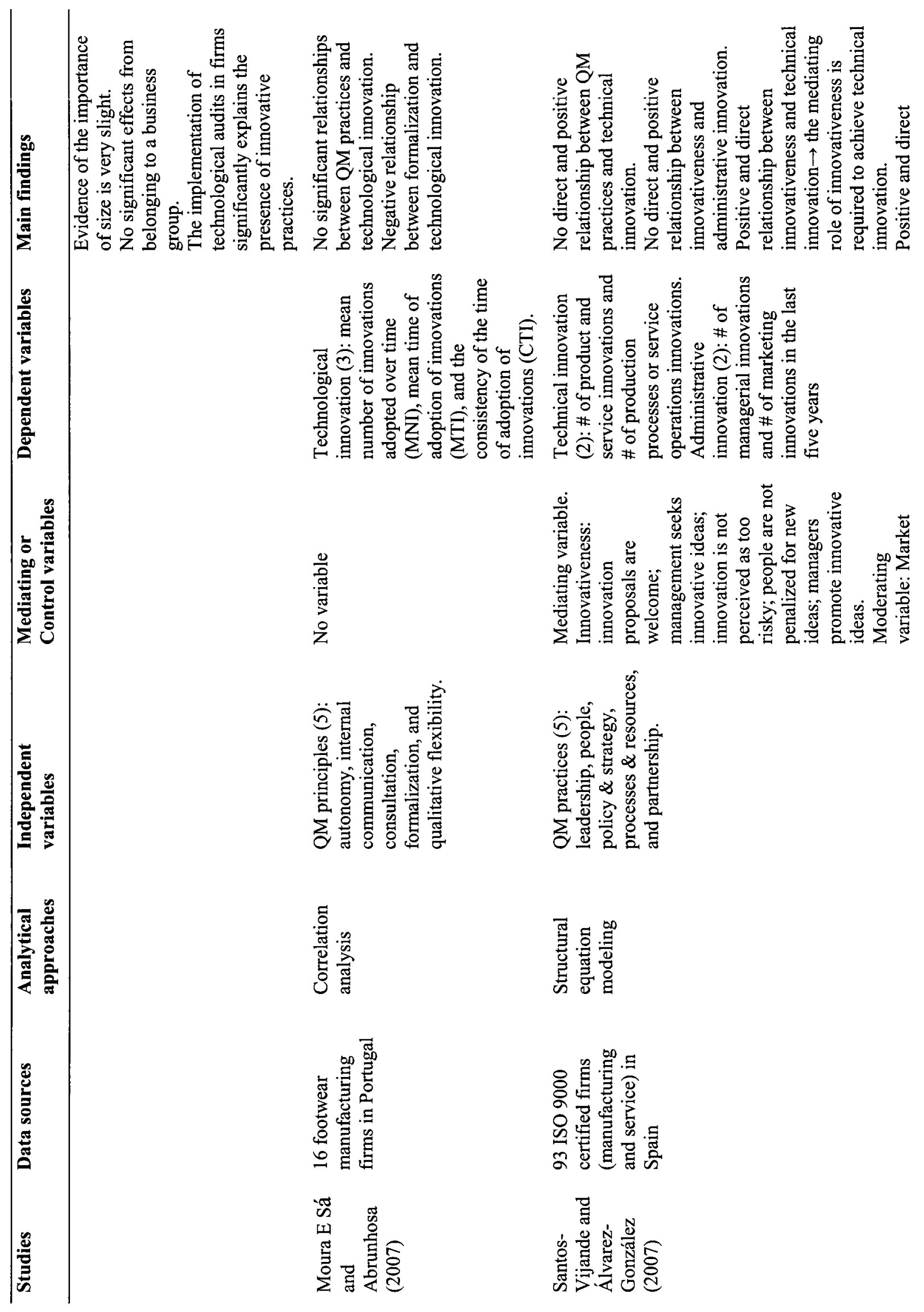




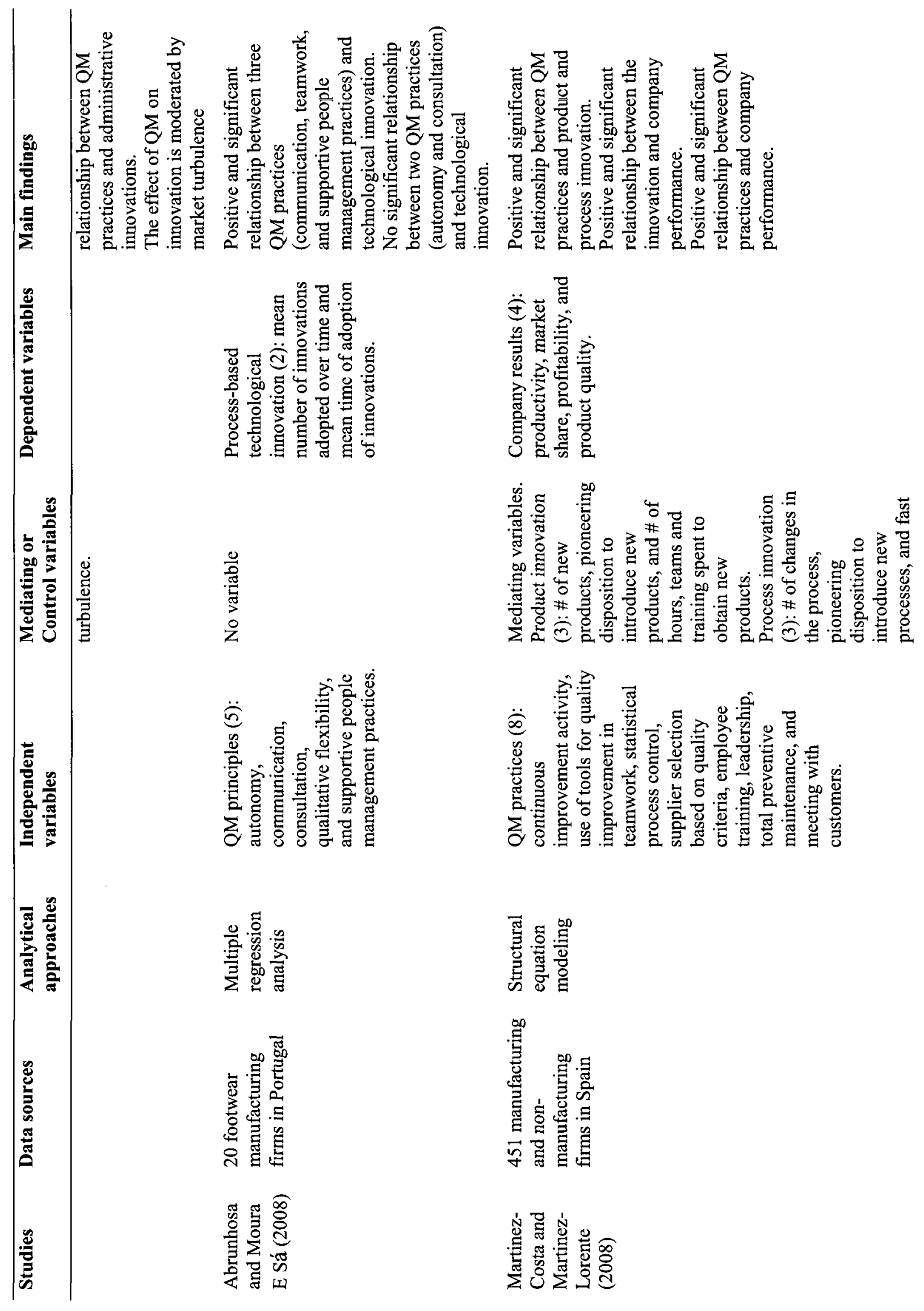

m 


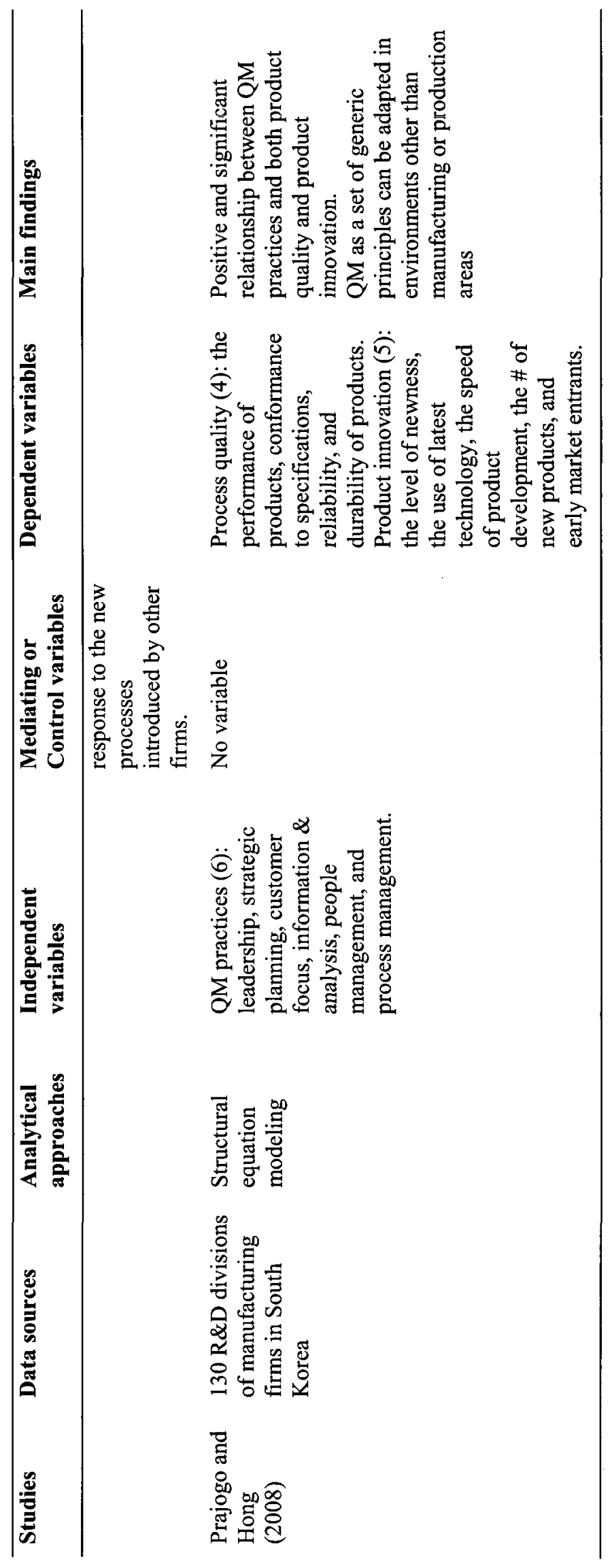




\section{Theoretical framework and hypotheses}

This section first provides a theoretical framework to address the relationships between QM practices and innovation. Then it develops research hypotheses based on the literature review.

\subsection{Theoretical framework}

The proposed framework (Figure 1) is developed to explore how and why QM practices are correlated with innovation. The framework reflects a core philosophy of QM: the entire organization is a system of interlocking processes (Soltani et al., 2004). The framework posits that the interaction effects and interrelationships among QM practices result in innovation (Nair, 2006). In terms of independent variables, this study utilizes a set of QM practices developed by Saraph et al. (1989).

The set of QM practices by Saraph et al. (1989) is widely cited in QM studies (Nair, 2006; Samson and Terziovski, 1999; Mehra et al., 2001; Sila and Ebrahimpour, 2005). The set of practices is often examined as one of the solid set of practices in replication studies (e.g., Kaynak, 2003; Quazi et al., 1998; Ho et al., 2001; Motwani et al., 1994; Kaynak and Hartley, 2005). This study, however, customizes the set of QM practices of Saraph et al. (1989). This is because a theory could be developed by integrating solid but old theories and recent theories. For instance, unlike the original set of practices proposed by Saraph et al. (1989), a set of QM practices in this study excludes one practice: the role of the quality department. The literature 
review shows that many organizations do not have a separate quality department (Kaynak, 2003). Instead, a new practice (customer relations) is added in this study because customer relations practices are broadly tested and recognized as a representative QM practice in many empirical studies (Brah et al., 2000; Powell, 1995; Mehra et al., 2001; Sila, 2007; Douglas and Judge, 2001; Zu et al., 2008; Samson and Terziovski, 1999). Thus, eight QM practices, such as management leadership and customer relations, are examined in this study.

With respects to a dependent variable, this study implements a comprehensive typology of innovation that is the most prominent classification in the innovation literature (Cooper, 1998; Zhao, 2005). This study examines five different types of innovation: radical product, radical process, incremental product, incremental process, and administrative innovation. In earlier studies, the innovation construct was operationalized in terms of a single item (product or process) or two items (product and process), not these multiple types of innovation. However, examining multiple aspects of innovation is essential to contribute to the development of the QM literature. This attempt will be helpful to understand the real impacts of QM practices on innovation and to interpret why earlier studies produced mixed findings. Furthermore, moderator effects between QM practices and innovation are examined. This study assumes that the intensity of the relationship between QM practices and innovation is moderated by the following factors: firm size, the duration of QM adoption, structural control, structural exploration, and industry.

To design causal relationships among QM practices, this study adopts a research model that was empirically examined by Kaynak (2003, see Appendix A). The causal model of Kaynak (2003) provides a foundation to develop hypotheses for this study. The proposed model in this study is, however, different from the model by Kaynak (2003) in the following three aspects. First, this study developes its own hypotheses associated with a dependent variable based on the 
innovation literature. Kaynak (2003) explored only the relationship between QM practices and traditional performances (quality, inventory, and financial and market performance). Unlike Kaynak's model (2003), the proposed model in this study examines the link between QM practices and five different types of innovation. Second, this study adds a hypothesis pertaining to a variable of QM practices, namely customer relation. Specifically, the proposed framework examines a link between employee relations, and quality data and reporting. The model of Kaynak (2003) did not encompass this link. On the other hand, the earlier studies widely advocated and proved the effects of customer relations (Flynn et al., 1995; Rungtusanatham et al., 1998; Ravichandran and Rai, 2000; Sila and Ebrahimpour, 2005; Zu et al; 2008). Third, in contrast to the model by Kaynak (2003), this study groups QM practices into two blocks: behavioural QM practices and mechanistic QM practices. This approach was suggested by Flynn et al. (1995), Ahire and Ravichandran (2001), and $\mathrm{Zu}$ et al. (2008). In this study, the behavioural practices encompass five components: management leadership, training, employee relations, supplier quality management, and customer relations (Flynn et al., 1995; Soltani et al., 2008; Rahman, 2004), while the mechanistic practices are related to quality data and reporting, process management, and product and service design (Hoang et al., 2006; Rahman, 2004; Lopez-Mielgo, et al., 2009; Flynn et al., 1995).

The basic premise of the framework holds that the impacts of each construct are based on the sequential nature of organizational transformation proposed by Ahire and Ravichandran (2001). This nature means that there is a cumulative effect of one practice on another practice. In addition, the impacts of a practice still exist along with other practices, while the practice already influenced other practices. This is because organizations continue to make an effort to find the impacts of QM practices. For example, management leadership influences training and employee 
relations. Both training and employee relations directly impact quality data and reporting. Quality and reporting, in turn, have an effect on process management that, consequently, influences innovation. However, the roles of the practices (e.g., management leadership) exist and should be emphasized continuously. This is mainly attributed to the fact that the practices are crucial determinants of other practices, such as training and employee relations. This is consistent with the fact that $\mathrm{QM}$ requires never-ending organizational and employee commitment and time (Yusuf et al., 2007). The remainder of this section discusses definitions of each of the framework's constructs, followed by the description of the hypotheses.

Figure 1. A priori theoretical framework

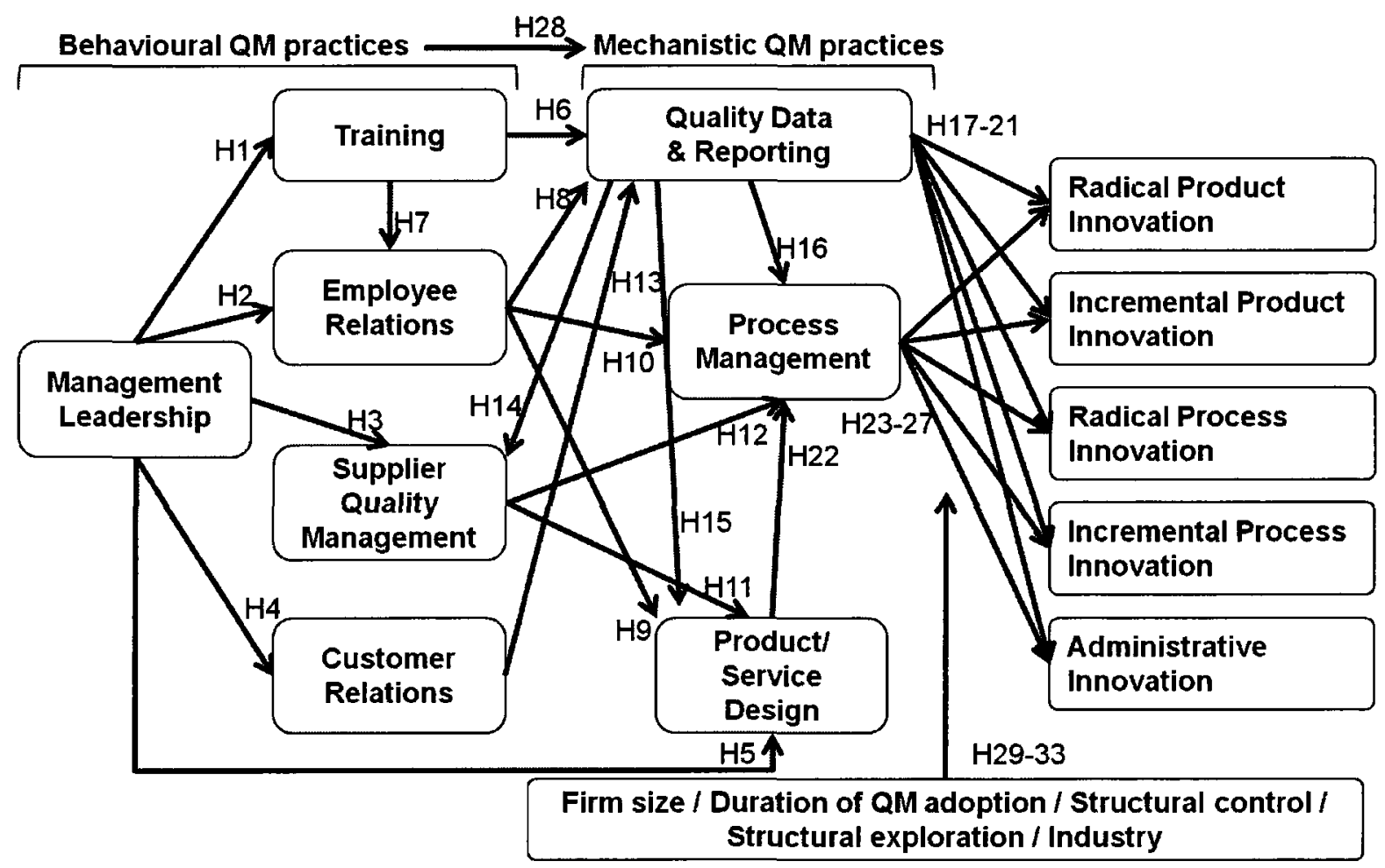




\subsection{Management leadership}

Management leadership refers to the extent to which top management establishes quality goals and strategies, allocates resources, participates in quality improvement efforts, and evaluates quality performance (Saraph et al., 1989; Anderson et al., 1994). It is essential to examine the impacts of management leadership along with other QM practices. The commitment of top management is generally a starting point for adopting QM and enhancing performance by affecting other QM practices (Ahir and Ravichandran, 2001; Sila and Ebrahimpour, 2005). The efforts of top management consequently contribute to creating a sophisticated QM infrastructure and driving changes across organizations (Ravichandran and Rai, 2000). It is impossible to build an effective environment for $\mathrm{QM}$ and produce performance of QM practices without strong top management support (Flynn et al., 1995). This study tests management leadership as an important antecedent of both other QM practices and innovation.

The commitment to QM can come only from the top management responsible for driving changes (Summers, 2009). Top management should establish a learning-intensive environment for the adoption of QM by ensuring adequate financial support for training and monitoring performance through training (Mehra et al., 2001; $\mathrm{Zu}$ et al., 2008). They know that the development of workforce skills and knowledge is a minimum requirement to achieve a better job and leads to a better understanding of employee roles (Besterfield et al., 2003). As a workforce motivator, top management also makes an effort to communicate with, motivate, and empower employees throughout the organization (Evans and Lindsay, 2008). It is imperative that top management makes individual employee knowledge and organizational goals consistent 
(Goetsch and Davis, 2006). Top management has to trust in the performance of employees, rather than trying to control employees (Besterfield et al., 2003). Distributing responsibilities and accountabilities enables employees to pay attention to organizational quality goals.

Top management establishes a long-term collaboration with suppliers. The role of suppliers is very important when obtaining high quality materials and leveraging unique knowhow and expertise (Lemke et al., 2003). Top management considers high quality to be the most important criterion when selecting a supplier. This is because top management understands that organizational competitiveness can be increased only if an organization relies on high quality materials, not cheap ones (Besterfield et al., 2003). Moreover, improving customer satisfaction can be accomplished by the commitment of top management. Top management outlines quality goals and plans based on customer satisfaction. Employees consider the goals and plans to be a baseline whenever they prioritize resources and necessary actions (Eng and Yusof, 2003). Next, using the quality-based principles, top management can motivate employees to be involved in design processes, develop teamwork, and enhance productivity (Saraph et al., 1989). It is top management that creates a focus on QM so that all affected departments are involved and that works out current or potential conflicts among departments.

Similarly, existing empirical studies broadly support direct and positive links between the following: management leadership and training (Anderson et al., 1995; Ravichandran and Rai, 2000; Kaynak, 2003), management leadership and employee relations (Flynn et al., 1995; Anderson et al., 1995; Ravichandran and Rai, 2000; Ahire and Ravichandran, 2001; Kaynak, 2003; Sila and Ebrahimpour, 2005; Zu et al., 2008), management leadership and supplier quality management (Flynn et al., 1995; Ahire and Ravichandran, 2001; Kaynak, 2003; Sila and Ebrahimpour, 2005; Zu et al., 2008), management leadership and customer relations (Flynn et 
al., 1995; Zu et al., 2008; Ahire and Ravichandran, 2001), and management leadership and product design (Flynn et al., 1995; Kaynak, 2003). In light of this information it is logical to expect that management leadership influences five QM practices: training, employee relations, supplier quality management, customer relations, and product design. Therefore, the previous discussion leads to the following hypotheses:

H 1: Management leadership will be positively associated with training.

H 2: Management leadership will be positively associated with employee relations.

H 3: Management leadership will be positively associated with supplier quality management.

H 4: Management leadership will be positively associated with customer relations.

H 5: Management leadership will be positively associated with product/service design.

\subsection{Training}

Training is identified as the extent to which an organization provides employees with knowledge related to statistics, job-related skills, and quality-oriented information, such as quality techniques. Training is considered to be a basic factor in the success of QM implementation (Bou and Beltran, 2005; Yusuf et al., 2007). Unless employees know how to implement concepts or techniques of QM in their jobs, employees might be resistant and not committed to change, instead of giving positive impacts and the effects of synergy to change (Soltani et al., 2005). A well-trained employee tends to work efficiently and effectively to 
improve performance ( $\mathrm{Zu}$ et al., 2008). It should be noted that an organization starts a training program by highlighting how QM can directly affect individual jobs and customer satisfaction (Summers, 2009). This approach helps employees to be involved in training proactively, taking steps to improve their weaknesses. Sources of training comprise in-house training, external training, and a combination of in-house and external (Goetsch and Davis, 2006). Depending on the objectives or contexts of training, organizations should select a type of training to improve productivity and performance.

Appropriate training provides several benefits, such as improving teamwork, decreasing errors or turnover rate, increasing flexibility, and establishing harmonious employee relations (Goetsch and Davis, 2006). In particular, training has a direct impact on the employees' way of working (Mehra et al., 2001). For example, training allows employees to view organizational systems as interlinked processes (Ravichandran and Rai, 2000). Employees recognize that they should build strong teamwork to work in the system and to manipulate individual perspectives. Furthermore, employees learn how to implement quality techniques (e.g., statistical process control, value flow chart, and benchmarking) and quality principles (e.g., fact-based approach, process approach, and customer relations). Without training, it is impossible for employees to measure performance, record results, analyze data, and monitor improvement efforts (Kaynak, 2003). Extant empirical evidence supports this discussion on the relationships among training, employee relations, and quality data/reporting. For instance, Ravichandran and Rai (2000), in an empirical study of 123 information system units, concluded that the development of employee skills significantly influences employee empowerment. Similarly, Kayank (2003), in a study of 214 manufacturing and service industries, found that training is directly related to both employee relations, and quality data and reporting. Therefore, the following hypotheses are proposed: 
H 6: Training will be positively associated with quality data and reporting.

H 7: Training will be positively associated with employee relations.

\subsection{Employee relations}

Employee relations in this context are defined as the extent to which employees are involved in quality efforts, participate in quality decisions, have responsibilities for quality, recognize superior quality performance, handle quality issues, and improve the general awareness about quality (Saraph et al., 1989). The success of QM implementation can be assured only if responsibility for quality is extended to all employees and all departments in an organization (Bou and Beltran, 2005; Eng and Yusof, 2003). Employees are the most important component in accomplishing success (Evans and Lindsay, 2008). An employee should understand how his or her job fits into the organizational goals and strategies to improve performance (Summers, 2009). In this line, employee relations should focus on encouraging employees to be involved in quality efforts and to be motivated and empowered. Further, organizations should know the crucial difference between involvement and empowerment. Involved employees are required to provide input but are not given ownership of their jobs; empowered employees are given ownership of their jobs and working processes (Goetsch and Davis, 2006). Creating a nonthreatening and creative environment helps to nurture empowered employees (Besterfield et al., 2003). This environment also facilitates the cross-functional problem solving and teamwork that are central to handling change (Yusuf et al., 2007). 
Empowered employees demonstrate a strong sense of ownership (Mehra et al., 2001). They understand the ways that products/services are designed and improved, and they may discover other ways that products/services could increase customer satisfaction (Summers, 2009). Employees struggle to learn quality tools and techniques, such as check sheets, flow charts, and statistical process control. It is a common view that an empowered employee effectively collects information, and measures and analyzes data (Kaynak, 2003; Zu et al., 2008). This is because the employee clearly understands the principle of continuing improvement. Further, an employee plays a key role in identifying, maintaining, and enhancing processes. An employee tries to implement quality improvement approaches, such as plan-do-check-act (PDCA). Various processes are also periodically audited by internal professionals, such as an auditor of the ISO 9001 quality management system. Using a team problem-solving approach and continual improvement, employees can improve product/service design (Choi and Eboch, 1998; Zu et al., 2008; Evans and Lindsay, 2008). Along the same line, empirical studies provided positive evidence about the following relationships: between employee relations and quality data/reporting (Ho et al., 2001; Flynn et al., 1995; Kaynak, 2003; Zu et al; 2008); employee relations and product/service design ( $\mathrm{Zu}$ et al., 2008); and employee relations and process management (Zu et al; 2008; Flynn et al., 1995; Rungtusanatham et al., 1998; Ravichandran and Rai, 2000; Sila and Ebrahimpour, 2005). Therefore, this discussion leads to the following hypotheses:

H 8: Employee relations will be positively associated with quality data and reporting.

H 9: Employee relations will be positively associated with product/service design. 
H 10: Employee relations will be positively associated with process management.

\subsection{Supplier quality management}

Supplier quality management is defined as the extent to which an organization depends on fewer suppliers, is interdependent with suppliers, emphasizes quality rather than price in the purchasing policy, and supports suppliers in product development (Saraph et al., 1989). Supplier quality management is recognized as one of the key elements because suppliers largely affect the overall cost and quality of products or services. For example, $60 \%$ of the cost of goods sold in 2000 was used to purchase raw materials, components, or goods (Besterfield et al., 2003). Leading companies struggle to establish a strong network with a small number of core suppliers (Summers, 2009). Companies understand that the strong partnership can be established only if they concentrate on critical success factors, such as trust, communication, conflict resolution techniques, commitment, and coordination (Mohr and Spekman, 1994; Brinkerhoff, 2002; Lambert et al., 2004; Maloni and Benton, 1997). Moreover, companies should not select suppliers based on the lowest bidder. This is because suppliers who bid low will find ways to reduce their losses, resulting in poor quality (Goetsch and Davis, 2006).

Supplier quality management has a direct impact on product/service design. In a longterm, successful partnership, suppliers are seriously involved in the buyers' product design teams where they offer key information about prospective components or materials (Flynn et al., 1995; Kaynak, 2003). Buyers and suppliers work together as partners and share information to maximize quality performance (Besterfield et al., 2003). Through this involvement, buyers take 
opportunities to identify customer needs, to standardize components, and to reduce redesigns ( $\mathrm{Zu}$ et al., 2008; Flynn et al., 1995). Furthermore, supplier quality management helps to improve organizational processes. With the introduction of the just-in-time (JIT) approach, buyers ask suppliers to provide high quality, small quantities of materials and frequent delivery. It is necessary for suppliers to provide exceptional quality and reduced setup times (Mehra et al., 2001; Besterfield et al., 2003). These efforts enable buyers to minimize not only variance in processes or components but also inventory costs (Kaynak, 2003). In light of this discussion, existing empirical studies support the following relationships: between supplier quality management and product/service design (Flynn et al., 1995; Kaynak, 2003; Zu et al., 2008) and supplier quality management and process management (Kaynak, 2003; Zu et al., 2008; Flynn et al., 1995). Therefore, the following hypotheses are proposed:

H 11: Supplier quality management will be positively associated with product/service design.

H 12: Supplier quality management will be positively associated with process management.

\subsection{Customer relations}

Customer relations are defined as the extent to which an organization emphasizes understanding customer needs (Ahire and Ravichandran, 2001). Examining the relationship between customer relations and other QM practices is important because customers are considered to be the most valuable asset to any organization (Besterfield et al., 2003; Ahire and Ravichandran, 2001). Organizations ensure that they provide a product or a service that 
customers really need and continually check to see if their product or service is reactive to current and emerging customer requirements (Yusuf et al., 2007; Samson and Terziovski, 1999). To accomplish these goals, the organizations tend to invite customers and show them production procedures, encourage customer feedback about their products or services, and offer information about emerging products (Flynn et al., 1995). Existing empirical studies found that customer relations are positively related to quality and reporting. For example, using data in 226 manufacturing plants in the United States, $\mathrm{Zu}$ et al. (2008) argued that a close relationship with customers facilitates the collection and use of data. This is because managers can easily collect first-hand information or data when they have a close relationship with customers. It is possible to expect that customer relations influence quality data and reporting. Therefore, this discussion leads to the following hypothesis:

H 13: Customer relations will be positively associated with quality data and reporting.

\subsection{Quality data and reporting}

Quality data and reporting is defined as the extent to which an organization uses quality data, uses feedback of quality data to employees for problem solving, measures quality on a regular basis, and evaluates employees based on quality performance (Saraph et al., 1989). Organizations commonly use quality data to maintain customer relations, to drive excellence, and to continue to enhance performance (Samson and Terziovski, 1999). Managing quality data is based on a key principle of QM: in the factual approach effective decisions should be 
grounded on the analysis of data and information (ISO, 2000). All employees, not just a quality control team, must be involved in activities to consistently collect data, to accurately analyze data, and to evaluate relevant results in a timely fashion (Yusuf et al., 2007; Zu et al., 2008). This is because all employees, as process owners in their jobs, are responsible for systematically managing data (Evans and Lindsay, 2008). It is helpful for organizations to use various QM techniques, such as statistical process control and Pareto charts (Nair, 2006).

Quality data has a positive impact on supplier quality management. For example, employees can use quality data when selecting a supplier, developing a specification, and assessing the performance of suppliers (Kaynak, 2003). Managing quality data enables companies to develop a set of performance indicators to assess a supplier's capability (Evans and Lindsay, 2008). Further, in a product and service design stage, it is essential for organizations to implement quality data to develop customer-based products and prevent redesign. This is due to the fact that the design processes tend to require much information and a wide range of data (Flynn et al., 1995). It is possible for employees to appropriately analyze and use quality data collected from all departments, such as marketing and R\&D (Zu et al., 2008). Moreover, another benefit of quality data is to help employees when modifying and improving processes (Kaynak, 2003). This is because quality data is constantly updated and revised, resulting in the creation of a new process or the improvement of an old process. Next, earlier studies showed that quality data can play a key role in achieving innovation. For instance, Miller (1995), in an empirical study of 45 large multinational firms, concluded that managing quality data is one of the most important QM practices that can be applicable to innovative activities. Along the same line, Mathur-De Vré (2000) found that QM practices help to develop confidence in the credibility and reliability of all the scientific data. Accordingly, Mathur-De Vré (2000) argued that it is 
important to manage the data to yield innovation - especially when multiple parties are involved in a single innovation project. Similarly, existing empirical studies supported relationships between the following: quality data/reporting and supplier quality management (Kaynak, 2003; Sila and Ebrahimpour, 2005; Zu et al., 2008), quality data/reporting and product/service design (Kaynak, 2003), and quality data/reporting and process management (Ravichandran and Rai, 2000; Kaynak, 2003). Therefore, the following hypotheses are proposed:

H 14: Quality data and reporting will be positively associated with supplier quality management.

H 15: Quality data and reporting will be positively associated with product and service design.

H 16: Quality data and reporting will be positively associated with process management.

H 17: Quality data and reporting will be positively associated with radical product innovation.

$\mathrm{H}$ 18: Quality data and reporting will be positively associated with incremental product innovation.

H 19: Quality data and reporting will be positively associated with radical process innovation.

H 20: Quality data and reporting will be positively associated with incremental process innovation.

H 21: Quality data and reporting will be positively associated with administrative innovation. 


\subsection{Product/service design}

Product/service design is defined as the extent to which: all departments are involved in design reviews; an organization emphasizes productivity; an organization makes specifications clear; an organization highlights quality, not roll-out schedule; and an organization avoids frequent redesigns (Saraph et al., 1989). Product/service design aims at increasing design quality and guaranteeing design for manufacturability (Nair, 2006; Flynn et al., 1995). Design quality leads to standardizing components, simplifying designs, and incorporating customer needs in design processes ( $\mathrm{Zu}$ et al., 2008). Organizations should encourage constant communication among customers, design engineers, and manufacturers (Flynn et al., 1995). These efforts translate what employees understand into specifications to appropriately design a product/service.

Earlier studies noted that there is a positive relationship between the product/service design and process management. A well-designed product/service is characterized by fewer and standardized components. These features result in efficient process management because employees can reduce process variance and process complexity (Kaynak 2003; Ahire and Dreyfus, 2000; Flynn et al., 1995). Product/service design allows employees to reduce unnecessary changes, to prevent quality problems, and to minimize failure rates ( $\mathrm{Zu}$ et al., 2008). Empirical studies also indicate that product/service design can facilitate process management. For example, Ahire and Dreyfus (2000), in a study of 418 manufacturing plants from multiple industries, found that design management has a strong and positive effect on process quality management. Similarly, using data from 214 manufacturing and service industries in the United 
States, Kaynak (2003) provided evidence to support the relationship between product/service design and process management. Therefore, this discussion leads to the following hypothesis:

H 22: Product/service design will be positively associated with process management.

\subsection{Process management}

Process management is defined as the extent to which: an organization clarifies process ownership, boundaries, and steps; an organization relies on less inspection; employees use quality techniques and automation; employees use fool-proof process design; and employees conduct self-inspection, preventive maintenance, and automated testing (Saraph et al., 1989). QM scholars highlighted that an organization is a set of interlinked processes. They believe that organizational performance can be improved through careful attention to developing these interlinked processes (Samson and Terziovski, 1999; Nair, 2006). This perspective is a foundation to motivate organizations to make an effort to develop processes. From an operational perspective, process management leads to the elimination of slack and of errors, and a reduction in variation (Yusuf et al., 2007; Choi and Eboch, 1998). From an organizational perspective, process management has a positive effect on improving quality, increasing output uniformity, and increasing aggregate performance (Ahire and Ravichandran, 2001; Flynn et al., 1995; Kaynak, 2003; Nair, 2006; Ravichandaran and Rai, 2000).

Empirical studies support the relationship between process management and innovation. For instance, Hoang et al. (2006), in an empirical study of 204 manufacturing and service firms, 
found that process management is positively related to innovation, such as the number of new products and the number of new functional solutions. Similarly, Perdomo-Ortiz et al. (2006), in an empirical study of 102 machinery and instruments firms, concluded that process management has a greater explanatory power over business innovation capability. Perdomo-Ortiz et al. (2006) underlined that process management outstandingly influences innovation capability. Prajogo and Hong (2008), in a study of 130 R\&D divisions of manufacturing firms, found that process management is directly and positively related to product innovation. Therefore, the following hypotheses are proposed:

H 23: Process management will be positively associated with radical product innovation.

H 24: Process management will be positively associated with incremental product innovation.

H 25: Process management will be positively associated with radical process innovation.

H 26: Process management will be positively associated with incremental process innovation.

H 27: Process management will be positively associated with administrative innovation.

\subsection{Behavioural practices versus mechanistic practices}

It is a common view that the impacts of behavioural QM practices can be achieved through mechanistic QM practices (Rahman, 2004). In this study, the proposed framework examines the relationship between behavioural and mechanistic practices. This is because the framework is based on the following narrative view: the appropriate application of behavioural 
practices (e.g., management leadership) leads to the enhancement of mechanistic practices (e.g., processes management); subsequently, the impacts of the mechanistic practices result in innovation. Examining the relationship between behavioural and mechanistic practices is important because some empirical studies questioned the role of mechanistic practices in yielding improved performance (Powell, 1995; Samson and Terziovski, 1999; Feng et al., 2006).

A few researchers made an effort to explain the mixed findings on the link between behavioural and mechanistic practices. For instance, Flynn et al. (1995), in a study of 42 manufacturing plants in the United States, found that behavioural (infrastructure) practices can establish an environment to support the effective use of the mechanistic QM practices. The mechanistic (core) practices, on the other hand, are directly associated with quality performance by concentrating on the application of quality tools and continuous improvement. Similarly, $\mathrm{Zu}$ et al. (2008) developed a research model that includes infrastructure practices and core practices. Using 226 U.S. manufacturing plants, they concluded that behavioural practices are significantly related to mechanistic practices. Zu et al. (2008) argued that dividing QM practices into the behavioural and mechanistic practices is helpful to better identify the complex relationship among QM practices. However, the lack of empirical studies limits our understanding of how the positive effect of the behavioural practices on innovation is mediated by mechanistic practices. More studies are required to obtain further clarity on the link between behavioural and mechanistic practices (Rahman, 2004; Sousa and Voss, 2002). The following hypothesis deserves testing:

H 28: Behavioural QM practices will be positively associated with mechanistic QM practices. 


\subsection{Moderating variables}

Proponents of $\mathrm{QM}$ advocated that the implementation of $\mathrm{QM}$ practices is universally beneficial in all types of organizations (Evans and Lindsay, 2008). While many organizations successfully implemented QM and improved their performance, a growing number of other organizations failed to accomplish benefits through QM (Douglas and Judge, 2001). Similarly, empirical studies questioned the QM proponents' arguments by positing that performance of QM can be achieved in an industry (e.g., manufacturing), but not in all types of organizations (e.g., Powell, 1995). To find an appropriate reason, researchers relied on the contingency theory - "an organization is above all an adaptive system which evolves by reacting to its environment" (Becheikh et al., 2006, p. 656). For example, rigorous academic studies criticized the universal validity of QM practices by arguing that the performance of QM adoption is contingent on organizational contexts (Sila, 2007; Sousa and Voss, 2002). Similarly, other studies called for more research on the identification of potential moderator variables and their roles in a different context (Zaho et al., 2004).

Unfortunately, researchers made little attempt to build a theory pertaining to the contextual variables. Furthermore, the inquiry into context dependence QM was developed at a slow pace (Nair, 2006). For instance, Sousa and Voss (2002), in a substantial literature review study, found only four studies that explored the contextual factors of QM practices. To further expand existing knowledge bases, this study examined three moderating factors - organizational structure, firm size, and the duration of QM adoption - that were regarded in the literature as important determinants of innovation and QM (Douglas and Judge, 2001; Salavou and Lioukas, 
2003; Idris and Zairi, 2006). Consistent with the views of Nair (2006), it can be argued that examining the moderating factors helps to explain the inconsistent findings on the relationship between QM practices and innovation. This study focuses on the following moderating factors: firm size, the duration of QM adoption, structural control, structural exploration, and industry.

First, understanding the moderating effect of firm size is crucial because different features of organizations can influence the effectiveness of QM (Hannan and Freeman, 1984; Sila, 2007; Yeung et al., 2006). Researchers reported different characteristics between small firms and large firms. Small firms, for example, are likely to be more customer focused, have good internal communication channels, have greater internal flexibility, have loose work processes and decentralized structures, are willing to take risks, and are more efficient (Bommer and Jalajas, 2004; Hendricks and Singhal, 2001; Teece et al., 1997; Sila, 2007). In this aspect, small firms are more innovative than large firms, so small firms tend to concentrate on creating radical innovation (De Propris, 2002; Broing and Herzog, 2008). In contrast, large firms have more employees and resources, more layers of management, a lack of internal flexibility, longstanding barriers among departments, formalized communication channels, and a bigger bureaucracy (Yeung et al., 2006; Hendricks and Singhal, 2001; Bommer and Jalajas, 2004; Germain and Spears, 1999). Large firms are likely to have difficulty accomplishing major changes in products or services (Mohrman et al., 1995). In this respect, large firms focus on current customers to generate returns today and on incremental innovation (Broring and Herzog, 2008; Bommer and Jalajas, 2004).

Existing studies support the moderating role of firm size on performance. For example, Hendricks and Singhal (2001), in an empirical study of 435 quality award winners, found that firm size is significantly related to the level of change in financial performance. According to 
Hendricks and Singhal (2001), small firms do better than large firms because small firms already have some features that are similar to principles of QM, such as customer relations. Small firms are likely to establish an effective environment for organizational learning and assist better understanding of customer needs. These advantages of small firms lead to much profit. Similarly, Lopez-Mielgo et al. (2009), in an empirical study based on Spanish official survey data, concluded that there is a positive relationship between organizational standardization and quality control activities and firm size. Therefore, it can be expected that firm size moderates the relationship between QM practices and innovation.

Second, researchers consider the duration of $Q M$ adoption to be one of the most important variables (e.g., Idris and Zairi, 2006). On the basis of the QM principle of continuous improvement, proponents of QM argued that the impacts of QM can be achieved only if organizations are involved in QM efforts for a long period, such as at least three years (Schmidt and Finnigan, 1992). The QM literature indicates that QM entails excessive amounts of management time and resources necessary to produce performance (Powell., 1995; Sila, 2007; Yeung et al., 2006). The long-term view on the implementation of QM is supported by previous studies. For instance, using data from 54 firms in the United States, Powell (1995) concluded that short-time adopters are less satisfied with QM programs than long-term adopters. Similarly, Ahire and Ravichandran (2001), in an empirical study of 407 plants in the automobile parts supplier industry, concluded that continuous learning on a long-term basis is positively related to quality performance. Reger et al. (1994) argued that the duration of QM implementation is significantly related to the degree to which organizations are involved in QM activities. Perdomo-Ortiz et al. (2006), in an empirical study of 102 machinery and instruments firms in 
Spain, found that organizations with a long history of QM are more likely to establish innovation capability.

Third, it is important to examine structural control and structural exploration, because a supportive organizational structure is an essential condition to improve the impacts of QM adoption (Shea and Howell, 1998). The organizational structure can be split into two types: structural control and structural exploration (Douglas and Judge, 2001). There is substantial difference between the two types. In the structural control, organizations are likely to be larger and more centralized with tight processes and cultures (Hoffman and Hegarty, 1993; Benner and Tushman, 2003). The control-oriented organizations have a structured channel of communication and restrain the free flow of information (Cooper, 1998; Abrunhosa and Moura E Sá, 2008). In contrast, structural exploration is small and decentralized with loose processes (Benner and Tushman, 2003). Exploration organizations encourage employees to be involved in open and extensive interpersonal channels of communication (Abrunhosa and Moura E Sá, 2008). Empirical studies supported the importance of organizational structure. For instance, Douglas and Judge (2001), in a study of 229 general medical hospitals, found that organizational structure significantly moderates the relationship between QM practices and performance. Therefore, it is possible to expect that organizational structure can make an effect on the link between QM practices and innovation. Finally, it will be tested if there is a moderating effect of industry on the relationship between QM practices and innovation. Depending on the type of industry, the impacts of QM management might be different. Data will be split into two types of industries in terms of high technology industry or low technology industry. The classification rule is based on guidance proposed by Kaynak and Hartley (2005) who considered high technology industry 
encompassing seven industries, such as chemicals and allied products and transportation equipment. The above discussion leads to the following hypotheses:

H 29: Firm size will moderate the relationship between QM and innovation.

H 30: The duration of QM adoption will moderate the relationship between QM and innovation.

H 31: Structural control will moderate the relationship between QM and innovation.

H 32: Structural exploration will moderate the relationship between QM and innovation.

H 33: Type of Industry will moderate the relationship between QM and innovation. 


\section{Methods}

This section presents the sample, data collection procedures, and measures used in this study.

\subsection{Sample and data collection}

A target sample of 2,100 ISO 9001 certified manufacturing or service companies, listed in the Scottsinfo.com database, was selected. A stratified sampling technique was used to obtain data from different sizes of companies: large-sized, medium-sized, and small-sized companies. Both manufacturing and service companies were considered for the following three reasons. First, QM was widely adopted and practised in the industries for the last few decades. Therefore, QM studies should be conducted for a broad range of industries. Second, innovation is considered to be an important option to build competitive advantage in any organization (Lloréns Montes et al., 2005; Veryzer, 1998; Di Benedetto et al., 2008). Third, the cross-sectional approach will increase the generalizability of findings beyond the bounds of a single industry. The argument that both manufacturing and services companies should be included is consistent with the sampling methods of previous empirical studies conducted in the manufacturing and

service industries (e.g., Hoang et al., 2006; Prajogo and Sohal, 2004; Santos-Vijande and Álvarez-González, 2007; Martinez-Costa and Martinez-Lorente, 2008). 
The unit of analysis is the organizational level as this study seeks to find out whether QM practices lead to organizational innovation. Earlier studies were conducted at the plant level (e.g., Flynn et al., 1995; Anderson et al., 1995; Rungtusanatham et al., 1998; Ahire and Ravichandran, 2001; Zu et al., 2008). However, an organizational level study will add depth to the QM literature since there is a relative lack of studies investigating linkages of QM practices (e.g., Kaynak, 2003; Sila and Ebrahimpour, 2005). Further, in designing a questionnaire, two guidelines suggested by Frohlich (2002) were considered as follows: increasing respondents' perceived relevance and reducing respondents' expected effort. ISO 9001 certified companies were selected to improve respondents' perceived relevance. This is because many companies invested in projects that provide training programs or maintain the ISO 9001 certification every three years. Further, to reduce respondents' perceived effort, a brief questionnaire was designed. The questionnaire contained only 65 questions. This attempt was aimed at reducing respondents' expected time and retaining respondents' attention while answering a questionnaire. With respect to the questions' reliability and validity, most questions were adapted or borrowed from the literature, so they were expected to clearly and appropriately operationalize constructs. However, to ensure the appropriateness of the constructs, eleven researchers reviewed the questionnaire and suggested improvements in terms of ambiguity and readability. The final version of the questionnaire was prepared through this revision procedure.

A questionnaire and a cover letter were mailed to 2,100 respondents. A total of 242 questionnaires were completed and returned. 23 questionnaires were returned undelivered because the respondents moved or were unknown. The 19 incomplete responses were excluded because of a large number of missing values for questions pertaining to innovation. One of the main reasons was that the questions are not applicable in companies. The analysis is based on a 
sample of 223 ISO 9001 certified manufacturing or service companies, and the response rate is 10.6 per cent (See Table 4).

The respondents were company executives, middle-level managers, and professional staff. It was assumed that they were sufficiently well informed of the extent and impacts of QM practices in their companies to provide correct information. Similarly, previous studies reported that the commitment and knowledge of the executives and managers is extremely crucial when implementing QM (e.g., Burke, 1999). The sample consisted of 22 service companies (9.9\%) and 201 manufacturing companies $(90.1 \%)$. The manufacturing companies represented the following industries: 10 primary metal manufacturing (4.5\%, NAICS code 331 ); 15 machinery manufacturing $(6.7 \%$, NAICS code 333$) ; 15$ transportation equipment manufacturing $(6.7 \%$, NAICS code 336); 13 chemical manufacturing (5.8\%, NAICS code 325); 29 fabricated metal product manufacturing (13.0\%, NAICS code 332$) ; 18$ computer and electronic product manufacturing (8.1\%, NAICS code 334); 11 electrical equipment, appliance, and component manufacturing (4.9\%, NAICS code 335); and other industries (40\%), such as construction and food packaging. In this study, seven industries (NAICS code 331, 333, 336, 325, 332, 334, and 335) were analyzed separately because earlier studies viewed them to be high technology organizations that tend to significantly create innovation (Kaynak and Hartley, 2005). To examine the interaction effects of the industry, this study examined the difference between high technology organizations and low technology organizations. Further, with respect to the duration of ISO 9001 adoption, about $71 \%$ (158) of the respondents stated that ISO 9001 system was implemented in their organizations for more than three years, while $28 \%$ (62) of the respondents stated that their organizations have been following the system for less than three years. Table 4 shows descriptive summary of respondents. 
Table 4. Descriptive summary of responcients

\begin{tabular}{ll}
\hline & Number of respondents \\
\hline Respondents & Mailed questionnaire: 2,100 \\
& Returned questionnaire: $23(1.1 \%)$ \\
& Completed questionnaire: $242(11.5 \%)$ \\
& Incomplete questionnaires: $19(0.9 \%)$ \\
& Usable responses: 223 (Response rate, $10.6 \%)$ \\
& Service: $22(9.9 \%)$ \\
& Primary metal manufacturing: $10(4.5 \%)$ \\
& Machinery manufacturing: $15(6.7 \%)$ \\
& Transportation equipment manufacturing: $15(6.7 \%)$ \\
& Chemical manufacturing: $13(5.8 \%)$ \\
& Fabricated metal product manufacturing: $29(13.0 \%)$ \\
& Computer and electronic product manufacturing: $18(8.1 \%)$ \\
& Electrical equipment, appliance, and component manufacturing: $11(4.9 \%)$ \\
& Other industries: $90(40 \%)$ \\
& Less than $50: 74(33.2 \%)$ \\
& Between 50 - $500: 105(47.1 \%)$ \\
& Over $500: 44(19.7 \%)$ \\
Size of organizations & Less than 3 years: $62(27.8 \%)$ \\
& More than 3 years: $158(70.9 \%)$ \\
Not applicable: $3(1.3 \%)$ \\
\hline
\end{tabular}

A screening procedure was performed on the data. Data were recorded into a Microsoft Excel file. To ensure the accuracy of data entry, the coded data were examined two times. Next, it was required to employ a technique dealing with missing observations. Although there is a debate on the use of an appropriate technique, it is a common view that the mean substitution for missing item is the most common and basic method (Chhabra et al., 2002; Kline, 2005; Roth and Switzer, 1995). Missing values (62) were replaced by the mean value of the variable. 
Further, normality of data was examined by testing for skewness, kurtosis, and outliers. It is important to examine normality when using structural equation modeling (SEM). One of the assumptions in SEM is that the data is normally distributed. A distribution is not normal if data shows skewness and kurtosis (Kline, 2005). Skewness refers to the asymmetry of a distribution, while kurtosis is a measure of the peakedness of a distribution (Mandelbrot, 1967). The literature shows that the distribution is normal when skewness ranges from -2 to +2 , and kurtosis ranges from -7.0 to +7.0 (Curran et al., 1996). Table 5 indicates that all of the indicator values are normally distributed.

Table 5. Descriptive statistics of indicators

\begin{tabular}{|c|c|c|c|c|c|c|}
\hline Item & Minimum & Maximum & Mean & $\begin{array}{r}\text { Std. } \\
\text { Deviation }\end{array}$ & $\begin{array}{r}\text { Skewness } \\
\text { Statistic }\end{array}$ & $\begin{array}{l}\text { Kurtosis } \\
\text { Statistic }\end{array}$ \\
\hline \multicolumn{7}{|c|}{ Items related to QM practices } \\
\hline MAL1 & 1 & 7 & 6.081 & 1.220 & -0.672 & -0.473 \\
\hline MAL2 & 1 & 7 & 5.973 & 1.178 & -0.509 & -0.540 \\
\hline MAL3 & 1 & 7 & 6.108 & 1.130 & -0.653 & -0.527 \\
\hline MAL4 & 1 & 7 & 5.507 & 1.342 & -0.344 & -0.611 \\
\hline MAL5 & 1 & 7 & 6.027 & 1.280 & -0.668 & -0.528 \\
\hline MAL6 & 1 & 7 & 5.942 & 1.349 & -0.620 & -0.566 \\
\hline TRA1 & 1 & 7 & 5.126 & 1.256 & -0.098 & -0.295 \\
\hline TRA2 & 1 & 7 & 5.027 & 1.135 & -0.078 & -0.203 \\
\hline TRA3 & 1 & 7 & 5.108 & 1.188 & -0.099 & -0.283 \\
\hline EMR1 & 1 & 7 & 5.072 & 1.088 & -0.069 & -0.203 \\
\hline EMR2 & 1 & 7 & 4.821 & 1.179 & -0.041 & -0.253 \\
\hline EMR3 & 1 & 7 & 5.197 & 1.138 & -0.108 & -0.284 \\
\hline EMR4 & 1 & 7 & 5.152 & 1.202 & -0.118 & -0.343 \\
\hline SQM1 & 1 & 7 & 5.184 & 1.348 & -0.163 & -0.525 \\
\hline SQM2 & 1 & 7 & 4.749 & 1.382 & -0.083 & -0.267 \\
\hline SQM3 & 1 & 7 & 4.462 & 1.321 & -0.058 & -0.140 \\
\hline
\end{tabular}




\begin{tabular}{|c|c|c|c|c|c|c|}
\hline Item & Minimum & Maximum & Mean & $\begin{array}{r}\text { Std. } \\
\text { Deviation }\end{array}$ & $\begin{array}{r}\text { Skewness } \\
\text { Statistic }\end{array}$ & $\begin{array}{l}\text { Kurtosis } \\
\text { Statistic }\end{array}$ \\
\hline SQM4 & 1 & 7 & 5.040 & 1.303 & -0.112 & -0.425 \\
\hline SQM5 & 1 & 7 & 4.691 & 1.362 & -0.066 & -0.277 \\
\hline SQM6 & 1 & 7 & 4.525 & 1.273 & -0.048 & -0.128 \\
\hline CUR1 & 1 & 7 & 5.619 & 1.231 & -0.297 & -0.548 \\
\hline CUR2 & 1 & 7 & 5.179 & 1.121 & -0.101 & -0.273 \\
\hline CUR3 & 1 & 7 & 5.498 & 1.158 & -0.209 & -0.392 \\
\hline CUR4 & 1 & 7 & 5.274 & 1.186 & -0.141 & -0.368 \\
\hline QDR1 & 1 & 7 & 5.157 & 1.276 & -0.140 & -0.443 \\
\hline QDR2 & 1 & 7 & 4.973 & 1.170 & -0.078 & -0.223 \\
\hline QDR3 & 1 & 7 & 5.049 & 1.171 & -0.104 & -0.184 \\
\hline QDR4 & 1 & 7 & 5.148 & 1.312 & -0.156 & -0.333 \\
\hline PSD1 & 1 & 7 & 5.247 & 1.247 & -0.149 & -0.434 \\
\hline PSD2 & 1 & 7 & 4.919 & 1.152 & -0.065 & -0.214 \\
\hline PSD3 & 1 & 7 & 5.085 & 1.130 & -0.123 & -0.169 \\
\hline PSD4 & 1 & 7 & 5.318 & 1.238 & -0.161 & -0.437 \\
\hline PRM1 & 1 & 7 & 4.498 & 1.150 & -0.040 & -0.050 \\
\hline PRM2 & 1 & 7 & 4.516 & 1.417 & 0.064 & -0.535 \\
\hline PRM3 & 1 & 7 & 4.673 & 1.188 & -0.033 & -0.211 \\
\hline PRM4 & 1 & 7 & 4.897 & 1.267 & -0.089 & -0.276 \\
\hline \multicolumn{7}{|c|}{ Items related to innovation } \\
\hline RPDI1 & 1 & 7 & 3.870 & 1.792 & 0.032 & -0.549 \\
\hline RPDI2 & 1 & 7 & 4.031 & 1.824 & -0.014 & -0.650 \\
\hline RPDI3 & $\mathbf{1}$ & 7 & 3.803 & 1.538 & 0.022 & -0.285 \\
\hline RPDI4 & 1 & 7 & 3.753 & 1.767 & 0.078 & -0.584 \\
\hline RPDI5 & 1 & 7 & 3.700 & 1.849 & 0.088 & -0.680 \\
\hline IPDI1 & 1 & 7 & 4.785 & 1.297 & -0.085 & -0.152 \\
\hline IPDI2 & 1 & 7 & 4.767 & 1.355 & -0.088 & -0.213 \\
\hline IPDI3 & 1 & 7 & 4.619 & 1.444 & -0.068 & -0.328 \\
\hline IPDI4 & 1 & 7 & 4.628 & 1.372 & -0.057 & -0.293 \\
\hline IPDI5 & 1 & 7 & 4.673 & 1.496 & -0.090 & -0.340 \\
\hline RPCI1 & 1 & 7 & 4.543 & 1.503 & -0.076 & -0.288 \\
\hline RPCI2 & 1 & 7 & 4.646 & 1.472 & -0.090 & -0.257 \\
\hline $\mathrm{RPCI} 3$ & 1 & 7 & 4.516 & 1.458 & -0.070 & -0.255 \\
\hline IPCI1 & 1 & 7 & 4.861 & 1.310 & -0.095 & -0.288 \\
\hline IPCI2 & 1 & 7 & 4.789 & 1.240 & -0.049 & -0.286 \\
\hline
\end{tabular}




\begin{tabular}{lrrrrrr}
\hline Item & Minimum & Maximum & Mean & $\begin{array}{r}\text { Std. } \\
\text { Deviation }\end{array}$ & $\begin{array}{r}\text { Skewness } \\
\text { Statistic }\end{array}$ & $\begin{array}{r}\text { Kurtosis } \\
\text { Statistic }\end{array}$ \\
\hline IPC13 & 1 & 7 & 4.744 & 1.316 & -0.049 & -0.393 \\
ADMI1 & 1 & 7 & 4.673 & 1.403 & -0.080 & -0.247 \\
ADMI2 & 1 & 7 & 4.220 & 1.295 & -0.023 & -0.115 \\
ADMI3 & 1 & 7 & 4.475 & 1.442 & -0.052 & -0.256 \\
ADMI4 & 1 & 7 & 3.511 & 1.879 & 0.138 & -0.693 \\
\hline
\end{tabular}

Labels: MAL, Management leadership; TRA, Training; EMR, Employee relations; SQM, Supplier quality management; CUR, Customer relations; QDR, Quality data \& reporting; PSD, Product/service design; PRM, Process management; RPDI, Radical product innovation; IPDI, Incremental product innovation; RPCI, Radical process innovation; IPCI, Incremental process innovation; ADMI, Administrative innovation.

Outliers refer to data points that split off or differ from rest of the data (Stevens, 1996, p. 12). The potential influence of outliers was assessed using the Mahalanobis distance statistics. The Mahalanobis distance represents the distance in standard deviation units between a set of scores for an individual case and the sample means for all variables (Kline, 2005, p. 51). It is assumed that the Mahalanobis distance is distributed as chi-square statistics (Kline, 2005). A chisquare $\left(\chi^{2}\right)$ test was performed to examine the Mahalanobis distance. There is no outlier if the Mahalanobis distance is lower than a critical value (26.13). Table 6 indicates that the Mahalanobis distance ranged from 1.221 to 25.880 . It is concluded that there is no evidence of outliers in the analysis.

Table 6. Result of test for analyzing outliers

\begin{tabular}{lrrrrr}
\hline & Minimum & Maximum & Mean & Std. Deviation & N \\
\hline Predicted Value & 2.810846 & 5.547184 & 4.469387 & .5578688 & 223 \\
Std. Predicted Value & -2.973 & 1.932 & .000 & 1.000 & 223
\end{tabular}


Standard Error of Predicted

Value

Adjusted Predicted Value

Residual

Std. Residual

Stud. Residual

Deleted Residual

Stud. Deleted Residual

Mahal. Distance

Cook's Distance

Centered Leverage Value
.067

.232

.129

.034

223

2.836820

$-2.5366664$

$-3.811$

$-3.844$

$-2.5807352$

$-3.975$

1.221

.000

.006

5.531468
1.3519892
2.031
2.073
1.4088610
2.090
25.880
.041
.117

.117

$$
4.470169
$$

.0000000

.000

$-.001$

$-.0007814$

$-.002$

7.964

.004

.036
.5583648

223

223

223

223

223

223

223

223

223

Critical value of eight independent variables $(p<0.001): 26.13$

Eight independent variables: Management leadership; Training; Employee relations; Supplier quality management; Customer relations; Quality data \& reporting; Product/service design; Process management Dependent variable: Innovation

To examine possible bias in a self-report survey data, a non-response bias test and Harmon's one-factor test were conducted. Non-response bias was assessed by performing a $t$ test on the scores of early and late respondents. A basic assumption is that the late respondents stand for opinions of non-respondents (Armstrong and Overton, 1977). Respondents were divided into two groups: 171 responses (76.7\%) that were received in December 2009 and 52 responses (23.3\%) that were received in January and February 2010 . The purpose of the analysis was to identify any difference between the two groups in eight independent variables (e.g., management leadership and customer relations) and five dependent variables (e.g., radical process innovation and administrative innovation). The $t$-test showed no significant difference in the two groups, indicating that the data is free from non-response bias. Table 7 shows results of student's $t$-test. 


\begin{tabular}{|c|c|c|c|c|c|c|c|c|c|c|}
\hline & & $\begin{array}{l}\text { Levene's } \\
\text { Equality of }\end{array}$ & $\begin{array}{l}\text { st for } \\
\text { ariances }\end{array}$ & & & & st for Equalit & of Means & & \\
\hline & & & & & & & Mean & Std. Error & $\begin{array}{l}95 \% \text { Confid } \\
\text { of the } D\end{array}$ & $\begin{array}{l}\text { Interval } \\
\text { rence }\end{array}$ \\
\hline & & $\mathrm{F}$ & Sig. & $t$ & $\mathrm{df}$ & (2-tailed) & Difference & Difference & Lower & Upper \\
\hline MAL & Equal variances & 2.298 & .131 & -.128 & 221 & .898 & -.0204303 & .1594435 & -.3346547 & .2937940 \\
\hline & assumed & & & & & & & & & \\
\hline & Equal variances not & & & -.154 & 120.472 & .878 & -.0204303 & .1322646 & -.2822946 & .2414339 \\
\hline & assumed & & & & & & & & & \\
\hline TRA & Equal variances & 1.172 & .280 & 1.055 & 221 & .293 & .1715774 & .1626576 & -.1489810 & .4921359 \\
\hline & assumed & & & & & & & & & \\
\hline & Equal variances not & & & 1.120 & 93.115 & .266 & .1715774 & .1532348 & -.1327116 & .4758665 \\
\hline & assumed & & & & & & & & & \\
\hline EMR & Equal variances & .509 & .476 & 1.606 & 221 & .110 & .24196 & .15069 & -.05501 & .53893 \\
\hline & assumed & & & & & & & & & \\
\hline & Equal variances not & & & 1.677 & 90.504 & .097 & .24196 & .14431 & -.04472 & .52864 \\
\hline & assumed & & & & & & & & & \\
\hline SQM & Equal variances & .113 & .737 & 1.216 & 221 & .225 & .1789436 & .1471231 & -.1110002 & .4688875 \\
\hline & assumed & & & & & & & & & \\
\hline & Equal variances not & & & 1.175 & 80.232 & .243 & .1789436 & .1522363 & -.1240029 & .4818901 \\
\hline & assumed & & & & & & & & & \\
\hline CUR & Equal variances & .269 & .604 & 1.142 & 221 & .255 & .17940 & .15715 & -.13031 & .48911 \\
\hline & assumed & & & & & & & & & \\
\hline & Equal variances not & & & 1.178 & 88.754 & .242 & .17940 & .15227 & -.12316 & .48196 \\
\hline & assumed & & & & & & & & & \\
\hline QDR & Equal variances & 3.049 & .082 & .446 & 221 & .656 & .07538 & .16893 & -.25754 & .40829 \\
\hline & assumed & & & & & & & & & \\
\hline & Equal variances not & & & .482 & 96.198 & .631 & .07538 & .15628 & -.23484 & .38559 \\
\hline & assumed & & & & & & & & & \\
\hline PSD & Equal variances & .015 & .904 & 1.170 & 221 & .243 & .19194 & .16402 & -.13130 & .51519 \\
\hline & assumed & & & & & & & & & \\
\hline & Equal variances not & & & 1.160 & 83.302 & .249 & .19194 & .16543 & -.13707 & .52095 \\
\hline & assumed & & & & & & & & & \\
\hline PRM & Equal variances & .043 & .836 & .601 & 221 & .548 & .08974 & .14930 & -.20450 & .38399 \\
\hline & assumed & & & & & & & & & \\
\hline & Equal variances not & & & .602 & 84.533 & .549 & .08974 & .14914 & -.20682 & .38630 \\
\hline & assumed & & & & & & & & & \\
\hline RPDI & Equal variances & 3.596 & .059 & -.179 & 221 & .858 & -.0443320 & .2473387 & -.5317762 & .4431122 \\
\hline & assumed & & & & & & & & & \\
\hline
\end{tabular}




\begin{tabular}{|c|c|c|c|c|c|c|c|c|c|c|}
\hline & Equal variances not & & & -.198 & 100.398 & .843 & -.0443320 & .2236871 & -.4880993 & .3994353 \\
\hline & assumed & & & & & & & & & \\
\hline \multirow[t]{2}{*}{ IPDI } & $\begin{array}{l}\text { Equal variances } \\
\text { assumed }\end{array}$ & 1.202 & .274 & -.804 & 221 & .422 & -.1580747 & .1966631 & -.5456498 & .2295004 \\
\hline & $\begin{array}{l}\text { Equal variances not } \\
\text { assumed }\end{array}$ & & & -.889 & 100.346 & .376 & -.1580747 & .1779046 & -.5110173 & .1948680 \\
\hline \multirow[t]{2}{*}{ RPCI } & $\begin{array}{l}\text { Equal variances } \\
\text { assumed }\end{array}$ & .006 & .936 & -.973 & 221 & .331 & -.2038911 & .2094579 & -.6166816 & .2088993 \\
\hline & $\begin{array}{l}\text { Equal variances not } \\
\text { assumed }\end{array}$ & & & -.955 & 82.021 & .342 & -.2038911 & .2134614 & -.6285323 & .2207501 \\
\hline \multirow[t]{2}{*}{ IPCI } & $\begin{array}{l}\text { Equal variances } \\
\text { assumed }\end{array}$ & 1.881 & .172 & -.971 & 221 & .332 & -.1795622 & .1848401 & -.5438369 & .1847126 \\
\hline & $\begin{array}{l}\text { Equal variances not } \\
\text { assumed }\end{array}$ & & & -.887 & 74.394 & .378 & -.1795622 & .2024158 & -.5828490 & .2237247 \\
\hline \multirow[t]{2}{*}{$\mathrm{ADMI}$} & $\begin{array}{l}\text { Equal variances } \\
\text { assumed }\end{array}$ & .042 & .838 & -1.092 & 221 & .276 & -.2089519 & .1913126 & -.5859823 & .1680786 \\
\hline & $\begin{array}{l}\text { Equal variances not } \\
\text { assumed }\end{array}$ & & & -1.082 & 83.152 & .283 & -.2089519 & .1931835 & -.5931757 & .1752720 \\
\hline
\end{tabular}

Labels: MAL, Management leadership; TRA, Training; EMR, Employee relations; SQM, Supplier quality management; CUR, Customer relations; QDR, Quality data \& reporting; PSD, Product/service design; PRM, Process management; RPDI, Radical product innovation; IPDI, Incremental product innovation; RPCI, Radical process innovation; IPCI, Incremental process innovation; ADMI, Administrative innovation.

The common method variance was tested using Harmon's one-factor test (Schriesheim, 1979). This is because the questionnaire in this study included most subjective measures completed by a single source (Scott and Bruce, 1994). Common method variance is identified as a potential error in which a correlation between two measures may be due to the fact that both come from the same source, rather than a substantive relationship between them (Rothbard, 2001, p. 679). Confirmatory factor analysis (CFA) using linear structural relations (LISREL) was conducted for Harmon's one-factor test (Boyer and Hult, 2005, b). A single latent factor would account for most of the covariance in variables if the data has a problem with the common method variance (Podsakoff and Organ, 1986; Barringer and Bluedorn, 1999). In other words, 
common method variance appears in a structural model that poorly fits the data (Kim, 2009). A single factor model using the construct of management leadership was analyzed. The analysis result indicated that the fit of the model is significantly worse $\left(\chi^{2}=5588.86\right.$; degree of freedom $=1274$; the ratio of $\chi^{2}$ to degree of freedom $=4.39$ ). Thus, the data is free from common method bias and non-response bias.

\subsection{Measures}

It is important to design measurement items that can capture the nature of variables. In this study, a total of 65 measures were adapted or borrowed from the literature. The measures are divided into three categories: independent variables (QM practices), dependent variables (innovation), and moderating variables (firm size, industry, structural control, structural exploration, and the duration of QM adoption). Most measures used a seven-point Likert-type scale ranging from strongly disagree to strongly agree. A similar attempt using the seven-point Likert type was also used in prior empirical studies (e.g., Ahire and Ravichandran, 2001; Zu et al., 2008).

Measurement items for QM practices were based on instruments originally developed by Saraph et al. (1989). Although numerous researchers used and customized the original survey instrument, this study adapted 31 measurement items tested by Kaynak (2003). In Kaynak`s (2003) study, the measurement items were examined in a relatively large sample size of 214 manufacturing and service industries. However, Kaynak (2003) missed a construct that is important when understanding a customer perspective. This study added a construct, which is 
entitled "customer relations." This is because establishing a good relationship with customers is one of the representative goals of QM. Measurement items for customer relations were borrowed from the studies of Flynn et al. (1995) and $\mathrm{Zu}$ et al. (2008). For example, the construct "customer relations" was measured by indicators evaluating the extent to which a company is in close contact with its customers, employees know their customers, customers give feedback on quality and delivery performance, and customers visit the office or workplace.

Measurement items for innovation were adapted from the innovation literature, such as Herrmann, et al. (2007), Chandy and Tellis (1998), Valle and Vázquez-Bustelo (2009), Jansen et al. (2006), and Martinez-Costa and Martinez-Lorente (2008). In particular, this study evaluates innovation with multiple measurement items. This attempt is consistent with that of prior studies (e.g., Wan et al., 2005), that argue that an empirical study on innovation should not rely on only a single or a few innovation related items, such as $R \& D$ expenditures and patent counts. In this study, for example, the construct of radical product innovation was operationalized by five items reflecting the extent to which new products differ substantially from other existing products, a company introduces radical product innovation into the market more frequently than competitors, a percentage of radical product innovations in the product range is significantly higher compared to the competition, the percentage of total sales from radical product innovation is up substantially, and a company is well known by customers for radical product innovations.

Moderating constructs were added to examine whether the constructs influence the relationship between QM practices and innovation. First of all, structural exploration and structural control were adapted from a study conducted by Douglas and Judge (2001). Following a guideline suggested by Douglas and Judge (2001), this study split organizational structure into two sub-areas: structural exploration and structural control. The construct "structural 
exploration" was operationalized by items tapping the extent to which a company allows the freedom to change previous practices to fit a changing environment and encourages the flow of operating and financial information. On the other hand, the construct "structural control" was operationalized using three items reflecting the extent to which a company highlights the control of systems, procedures, and job descriptions. Another moderating construct was firm size representing a small-sized company (fewer than 50), a medium-sized company (between 50 and 500), and a large-sized company (more than 500). This classification is based on studies which analyzed Canadian businesses sectors (e.g., Debus, 2005). The classification is appropriate for this study since data were collected in Canadian manufacturing and service companies. Another moderating construct, the duration of $\mathrm{QM}$ adoption, was operationalized by the following indicators: less than 3 years; more than 3 years; not applicable. The measures for the constructs were adapted from earlier studies, such as Terziovski et al. (1997) and Powell (1995). Individual measurement items and definitions are given in Appendix B and C. 


\section{Analysis and results}

This section describes the analysis results of the measurement models and hypothesis testing.

Structural equation modeling (SEM) technique using LISREL was employed to analyze the measurement models and the structural models in this study. SEM is a technique to specify, estimate, and evaluate models of linear relationships among a set of observed variables in terms of a generally smaller number of unobserved variables (Shah and Goldstein, 2006, p. 149). Both measurement models and structural models can be examined using SEM (Gefen et al., 2000). A SEM model comprises of latent variables and observed variables. Each latent variable consists of a different number of observed variables (Kline 2005). SEM enables researchers not only to identify estimates of the model parameters and standard errors, but also to explore multiple relationships simultaneously (Kerlinger and Lee, 2000).

\subsection{Measurement analysis}

It is essential to test hypotheses without any measurement influences related to reliability, unidimensionality, and validity (Shah and Goldstein, 2006). A three-stage approach was employed to ensure that measurement items are reliable, unidimensional, and valid. 


\section{Reliability Assessment}

In the first stage, reliability was assessed to identify the degree to which measures are free from random measurement error (Kline, 2005). Reliability refers to the instrument's ability to offer consistent results over time (Gatewood and Field, 1990). CFA using LISREL was performed to explore reliability. Based on the results of CFA, two different methods were used (Carr and Pearson, 1999; Boyer and Hult, 2005 b) analyzing the squared multiple correlation $\left(R^{2}\right)$ and examining the composite reliability and the average variance extracted.

First, reliability was examined by analyzing the squared multiple correlation $\left(\mathrm{R}^{2}\right)$ of individual items. The $\mathrm{R}^{2}$-values in a measurement model were computed as one minus the ratio of the disturbance variance over the total variance (Kline, 2005, p. 252). Within the CFA setting, the $R^{2}$ value of an individual item should be greater than 0.30 (Carr and Pearson, 1999). However, it was found that the $\mathrm{R}^{2}$ values of four items were below 0.30: SQM2 (0.14), SQM3 (0.07), PRM2 (0.15), and ADMI4 (0.18). Thus, based on the analysis results, four items were dropped at this stage.

Further, the composite reliability and the average variance extracted were calculated using completely standardized solutions in the CFA results. (See formulas in Table 8) These two indices are widely used to test for reliability in the literature (e.g., Hult et al., 2004). According to a rule of thumb, the composite reliability of over 0.7 or the average variance extracted of over 0.5 indicates acceptable reliability levels (Fornell and Larcker, 1981; Kim, 2009). As Table 10 shows, the composite reliabilities ranged from 0.795 to 0.935 , while the average variance 
extracted ranged from 0.564 to 0.742 . The results reveal that all measures have a reasonable level of reliability.

Table 8. Formulas to calculate composite reliability and average variance extracted

\begin{tabular}{|c|c|c|}
\hline & Formula & \\
\hline Composite reliability (CR) & $C R_{\eta}=\frac{\left(\sum \lambda \gamma_{i}\right)^{2}}{\left(\sum \lambda \gamma_{i}\right)^{2}+\left(\sum \varepsilon_{i}\right)}$ & $\begin{array}{l}\mathrm{CR} \eta=\text { composite reliability for scale } \eta \\
\lambda \gamma_{\mathrm{i}}=\text { standardized loading for scale item } \gamma_{\mathrm{i}} \\
\varepsilon_{\mathrm{i}}=\text { measurement error for scale item } \gamma_{\mathrm{i}}\end{array}$ \\
\hline Average variance extracted (AVE) & $V_{\eta}=\frac{\left(\sum \lambda \gamma_{i}^{2}\right)}{\left(\sum \lambda \gamma_{i}^{2}\right)+\left(\sum \varepsilon_{i}\right)}$ & $\begin{array}{l}\mathrm{V} \eta=\text { average variance extracted for scale } \eta \\
\lambda \gamma_{\mathrm{i}}=\text { standardized loading for scale item } \gamma_{\mathrm{i}} \\
\varepsilon_{\mathrm{i}}=\text { measurement error for scale item } \gamma_{\mathrm{i}}\end{array}$ \\
\hline
\end{tabular}

Source: Boyer and Hult (2005, b, p. 653)

\section{Unidimensionality Assessment}

In the second stage, to test for unidimensionality, exploratory factor analysis (EFA) and CFA were performed. Unidimensionality refers to the extent to which the measures in a scale reflect one underlying construct (Venkatraman and Grant, 1986). To satisfy the requirement for unidimensionality, an indicator should rely on just one factor, while error terms are independent (Anderson and Gerbing, 1988). SPSS was employed for conducting EFA using principle component analysis with a varimax rotation. Items of QM practices and those of innovation were 
separately analyzed. Unidimensionality could be established if an eigenvalue of each item is greater than 0.40 (Bhuian et al., 2005). The eigenvalues indicate that measurement items for QM were loaded onto eight factors and that measurement items for innovation were loaded onto five factors. Eigenvalues of all items ranged from 0.550 to 0.904 (See Appendixes D and E).

CFA was also conducted to test for unidimensionality. The model fit was assessed by reviewing a set of indices: Comparative Fit Index (CFI), Root Mean Square Error of Approximation (RMSEA), the ratio of $\chi^{2}$ to degree of freedom $\left(\chi^{2} / \mathrm{df}\right)$, Normed Fit Index (NFI), and Non-Normed Fit Index (NNFI). The literature suggested that the use of a set of indices is superior to the application of a single index because each index has strengths and weaknesses (Kline, 2005; Hu and Bentler, 1999). For example, RMSEA is likely to overreject models at a small sample size (Hu and Bentler, 1999), while CFI is a relatively stable fit index (Gerbing and Anderson, 1992). The indices have different rules to determine excellent fit as follows: CFI, NFI, and NNFI > 0.9 (Bentler and Bonett, 1980; Byrne, 1998); RMSEA < 0.08 (Browne and Cudeck, 1993); $\chi^{2} / \mathrm{df}<3.0$ (Carmines and Mclver, 1981; Bollen, 1989).

CFA was conducted to separately examine measurement models of each construct, such as management leadership, training, and employee relations. The goodness of fit statistics showed a good fit of all measurement models to the data (See Appendixes F and G). Moreover, after testing the measurement models of each construct, CFA was again performed to assess two measurement models: one for QM practices and the other for innovation. This attempt at assessing the two measurement models is consistent with an assessment methodology suggested by Kaynak (2003). In terms of additional information, the results of CFA show an acceptable fit for both measurement models. In the measurement model for QM practices, the indices are as follows: $\mathrm{CFI}=0.99 ; \mathrm{RMSEA}=0.039 ; \chi^{2} / \mathrm{df}=630 / 456=1.38 ; \mathrm{NFI}=0.96 ;$ and $\mathrm{NNFI}=0.99$. 
Similarly, the measurement model for innovation shows good fit statistics: CFI $=0.97$; RMSEA $=0.077 ; \chi^{2} / \mathrm{df}=316 / 147=2.15 ; \mathrm{NFI}=0.94 ;$ and NNFI $=0.96$. Thus, it is concluded that all constructs are unidimensional. Table 9, Figure 2, and Figure 3 show analysis results of the measurement models.

Table 9. Analysis results of the measurement models

\begin{tabular}{|c|c|c|c|}
\hline Goodness of fit statistics & $\begin{array}{l}\text { Measurement model for QM } \\
\text { practices }\end{array}$ & $\begin{array}{l}\text { Measurement model for } \\
\text { innovation }\end{array}$ & $\begin{array}{l}\text { Suggested values for fitting } \\
\text { date (Source) }\end{array}$ \\
\hline $\begin{array}{l}\text { Comparative Fit Index } \\
\text { (CFI) }\end{array}$ & 0.99 & 0.97 & $\begin{array}{l}\quad>0.9 \\
\text { (Bentler and Bonett, 1980; } \\
\text { Byrne, 1998) }\end{array}$ \\
\hline $\begin{array}{l}\text { Root Mean Square Error of } \\
\text { Approximation (RMSEA) }\end{array}$ & 0.039 & 0.077 & $\begin{array}{c}<0.08 \\
\text { (Browne and Cudeck, 1993) }\end{array}$ \\
\hline $\begin{array}{l}\text { the ratio of } \chi^{2} \text { to degree of } \\
\text { freedom }\left(\chi^{2} / \mathrm{df}\right)\end{array}$ & $630 / 456=1.38$ & $316 / 147=2.15$ & $\begin{array}{l}\quad<3.0 \\
\text { (Carmines and Mclver, 1981; } \\
\text { Bollen, 1989). }\end{array}$ \\
\hline Normed Fit Index (NFI) & 0.96 & 0.94 & $\begin{array}{l}\quad>0.9 \\
\text { (Bentler and Bonett, 1980; } \\
\text { Byrne, 1998) }\end{array}$ \\
\hline $\begin{array}{l}\text { Non-Normed Fit Index } \\
(\mathrm{NNFI)}\end{array}$ & 0.99 & 0.96 & $\begin{array}{l}\quad>0.9 \\
\text { (Bentler and Bonett, 1980; } \\
\text { Byrne, 1998) }\end{array}$ \\
\hline
\end{tabular}


Figure 2. A measurement model for QM practices

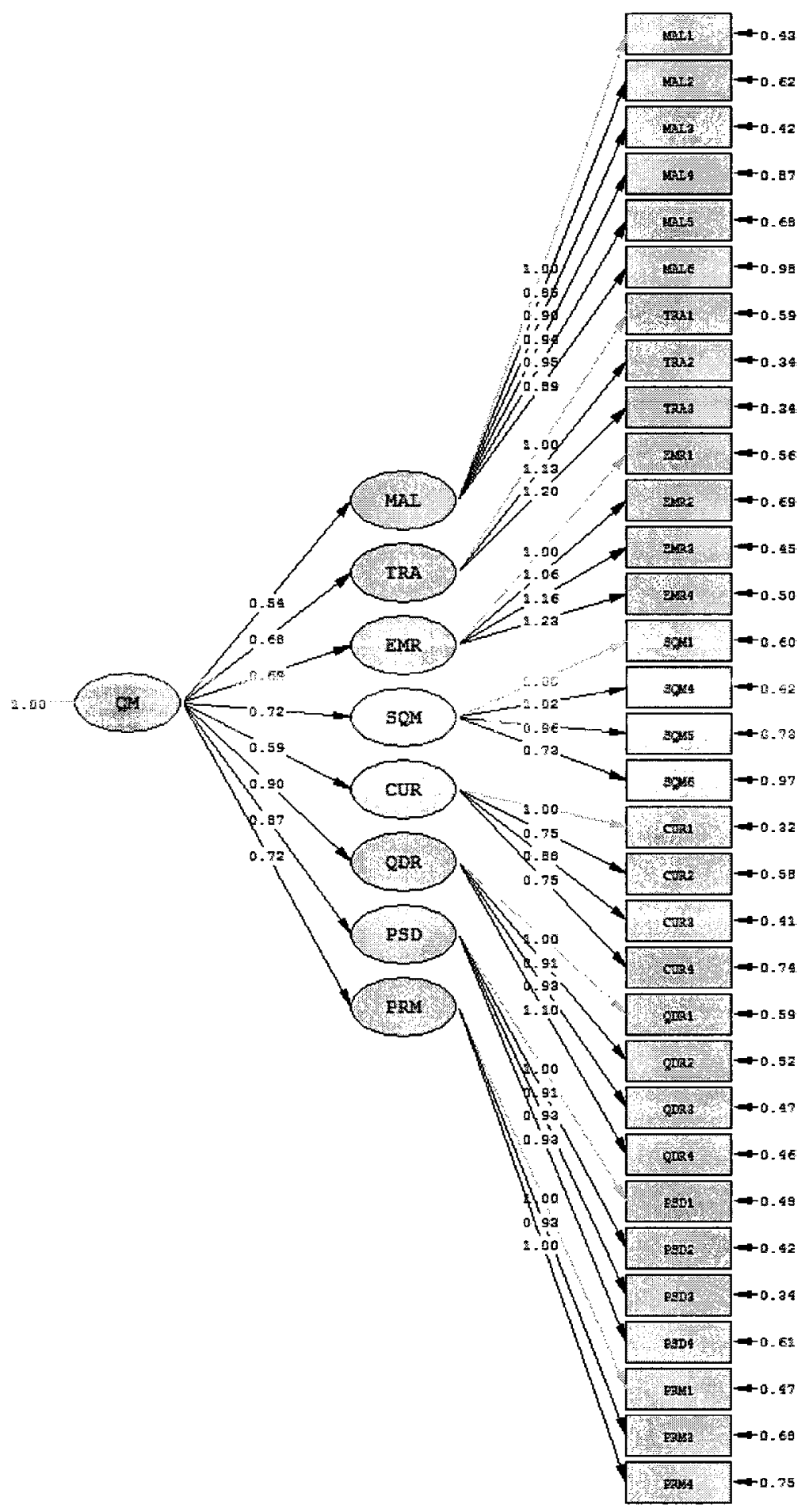

Chi一-9guzI= $=609.22$, df=45E, f- 


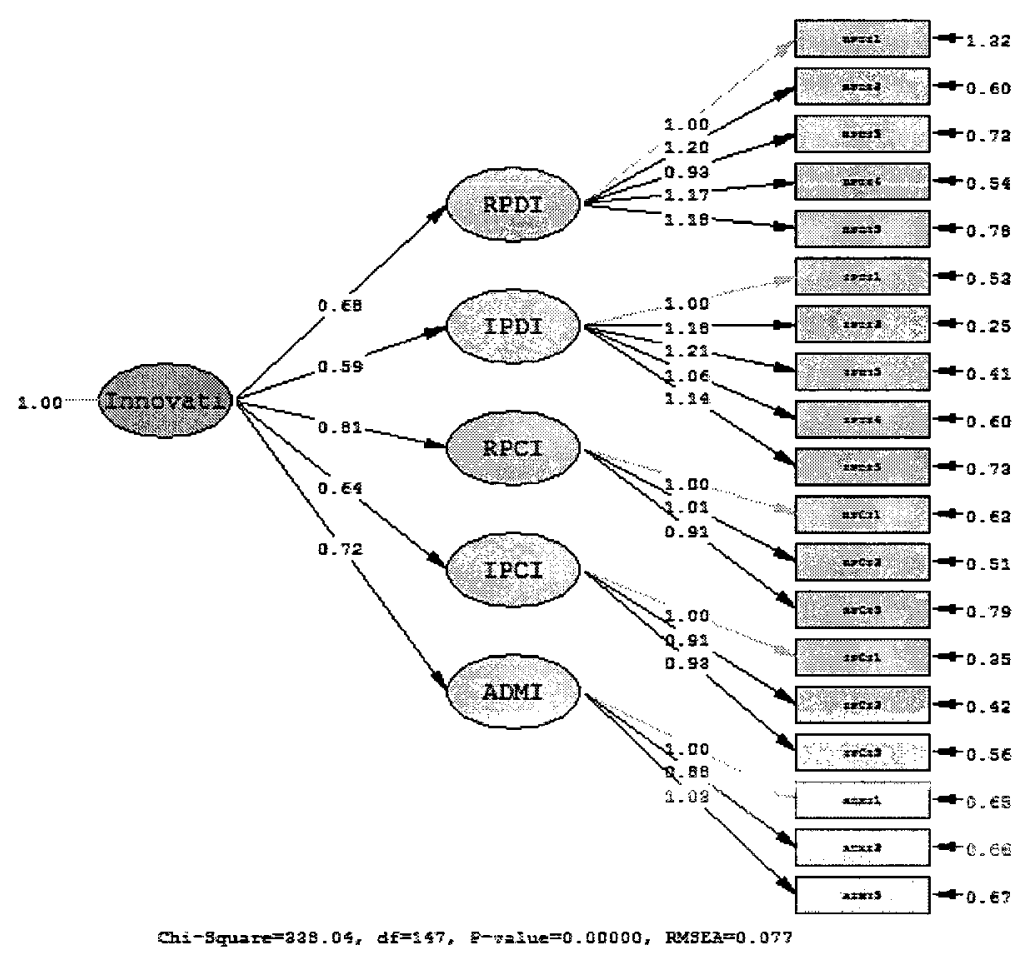

\section{Validity Assessment}

In the third stage, validity was assessed in terms of convergent validity and discriminant validity. Convergent validity is identified as the extent to which multiple attempts to measure the same concept are in agreement (Bagozzi and Phillips, 1982). Convergent validity can be evaluated by examining the $t$-value from CFA (Chen et al., 2004; Sila and Ebrahimpour, 2005). Each item's coefficients on its underlying construct were observed (Anderson and Gerbing, 1988). A measure should have convergent validity if the value of its coefficient is greater than 
twice its standard error. In other words, the $t$-values should be greater than two to achieve strong convergent validity, where the $t$-values are calculated by dividing the value of the coefficient by the standard error. The $t$-values in this study ranged from 9.811 to 17.970 . All measures have strong evidence of convergent validity.

Table 10. Factor loading, standardized loading, standard errors, and t-values

\begin{tabular}{|c|c|c|c|c|c|c|c|}
\hline $\begin{array}{l}\text { Factors } \\
\text { and items }\end{array}$ & $\begin{array}{l}\text { Factor } \\
\text { loading }\end{array}$ & $\begin{array}{l}\text { Standardized } \\
\text { loading }\end{array}$ & $\begin{array}{l}\text { Standard } \\
\text { error }\end{array}$ & $t$-value & $\mathbf{R}^{2}$ & $\begin{array}{l}\text { Composite } \\
\text { reliability }\end{array}$ & $\begin{array}{l}\text { Average variance } \\
\text { extracted (AVE) }\end{array}$ \\
\hline MAL & & & & & & 0.893 & 0.584 \\
\hline MAL1 & 1.000 & 0.841 & - & - & 0.708 & & \\
\hline MAL2 & 0.855 & 0.745 & 0.068 & 12.560 & 0.556 & & \\
\hline MAL3 & 0.896 & 0.814 & 0.063 & 14.247 & 0.663 & & \\
\hline MAL4 & 0.937 & 0.717 & 0.079 & 11.899 & 0.514 & & \\
\hline MAL5 & 0.960 & 0.770 & 0.073 & 13.150 & 0.593 & & \\
\hline MAL6 & 0.901 & 0.686 & 0.080 & 11.219 & 0.470 & & \\
\hline TRA & & & & & & 0.866 & 0.685 \\
\hline TRA1 & 1.000 & 0.744 & - & - & 0.554 & & \\
\hline TRA2 & 1.143 & 0.867 & 0.090 & 12.709 & 0.751 & & \\
\hline TRA3 & 1.195 & 0.865 & 0.094 & 12.692 & 0.749 & & \\
\hline EMR & & & & & & 0.850 & 0.586 \\
\hline EMR1 & 1.000 & 0.730 & - & - & 0.533 & & \\
\hline EMR2 & 1.052 & 0.709 & 0.104 & 10.079 & 0.502 & & \\
\hline EMR3 & 1.156 & 0.808 & 0.101 & 11.479 & 0.652 & & \\
\hline EMR4 & 1.227 & 0.811 & 0.106 & 11.527 & 0.658 & & \\
\hline SQM & & & & & & 0.859 & 0.607 \\
\hline SQM1 & 1.000 & 0.817 & - & - & 0.668 & & \\
\hline SQM4 & 1.019 & 0.862 & 0.073 & 14.042 & 0.743 & & \\
\hline SQM5 & 0.967 & 0.782 & 0.077 & 12.615 & 0.612 & & \\
\hline SQM6 & 0.737 & 0.638 & 0.075 & 9.811 & 0.407 & & \\
\hline CUR & & & & & & 0.868 & 0.625 \\
\hline CUR1 & 1.000 & 0.886 & - & - & 0.785 & & \\
\hline CUR2 & 0.759 & 0.739 & 0.060 & 12.675 & 0.546 & & \\
\hline CUR3 & 0.884 & 0.833 & 0.059 & 14.980 & 0.694 & & \\
\hline CUR4 & 0.748 & 0.688 & 0.065 & 11.463 & 0.473 & & \\
\hline QDR & & & & & & 0.886 & 0.661 \\
\hline QDR1 & 1.000 & 0.794 & - & - & 0.631 & & \\
\hline QDR2 & 0.909 & 0.787 & 0.071 & 12.766 & 0.620 & & \\
\hline
\end{tabular}




\begin{tabular}{|c|c|c|c|c|c|c|c|}
\hline $\begin{array}{l}\text { Factors } \\
\text { and items }\end{array}$ & $\begin{array}{l}\text { Factor } \\
\text { loading }\end{array}$ & $\begin{array}{l}\text { Standardized } \\
\text { loading }\end{array}$ & $\begin{array}{l}\text { Standard } \\
\text { error }\end{array}$ & $t$-value & $\mathrm{R}^{2}$ & $\begin{array}{l}\text { Composite } \\
\text { reliability }\end{array}$ & $\begin{array}{l}\text { Average variance } \\
\text { extracted (AVE) }\end{array}$ \\
\hline QDR3 & 0.934 & 0.808 & 0.071 & 13.209 & 0.654 & & \\
\hline QDR4 & 1.115 & 0.861 & 0.078 & 14.321 & 0.742 & & \\
\hline PSD & & & & & & 0.895 & 0.680 \\
\hline PSD1 & 1.000 & 0.835 & - & - & 0.697 & & \\
\hline PSD2 & 0.912 & 0.824 & 0.063 & 14.520 & 0.680 & & \\
\hline PSD3 & 0.928 & 0.856 & 0.061 & 15.332 & 0.732 & & \\
\hline PSD4 & 0.925 & 0.788 & 0.069 & 13.354 & 0.606 & & \\
\hline PRM & & & & & & 0.795 & 0.564 \\
\hline PRM1 & 1.000 & 0.785 & - & - & 0.617 & & \\
\hline PRM3 & 0.958 & 0.729 & 0.092 & 10.451 & 0.532 & & \\
\hline PRM4 & 1.034 & 0.737 & 0.098 & 10.563 & 0.543 & & \\
\hline RPDI & & & & & & 0.934 & 0.739 \\
\hline RPDI1 & 1.000 & 0.766 & - & - & 0.587 & & \\
\hline RPDI2 & 1.205 & 0.907 & 0.081 & 14.908 & 0.823 & & \\
\hline RPDI3 & 0.931 & 0.831 & 0.070 & 13.380 & 0.691 & & \\
\hline RPDI4 & 1.170 & 0.909 & 0.078 & 14.947 & 0.826 & & \\
\hline RPDI5 & 1.181 & 0.877 & 0.083 & 14.303 & 0.769 & & \\
\hline IPDI & & & & & & 0.935 & 0.742 \\
\hline IPDI1 & 1.000 & 0.826 & - & - & 0.681 & & \\
\hline IPDI2 & 1.178 & 0.930 & 0.066 & 17.970 & 0.866 & & \\
\hline IPDI3 & 1.208 & 0.896 & 0.071 & 16.931 & 0.804 & & \\
\hline IPDI4 & 1.058 & 0.826 & 0.071 & 14.858 & 0.682 & & \\
\hline IPDI5 & 1.149 & 0.822 & 0.078 & 14.759 & 0.676 & & \\
\hline RPCI & & & & & & 0.878 & 0.705 \\
\hline RPCI1 & 1.000 & 0.849 & - & - & 0.721 & & \\
\hline RPCI2 & 1.012 & 0.877 & 0.069 & 14.705 & 0.769 & & \\
\hline RPCI3 & 0.904 & 0.791 & 0.068 & 13.324 & 0.626 & & \\
\hline IPCI & & & & & & 0.891 & 0.733 \\
\hline IPCI1 & 1.000 & 0.892 & - & - & 0.796 & & \\
\hline IPCI2 & 0.906 & 0.854 & 0.058 & 15.753 & 0.729 & & \\
\hline IPCI3 & 0.924 & 0.820 & 0.062 & 14.984 & 0.673 & & \\
\hline ADMI & & & & & & 0.848 & 0.651 \\
\hline ADMI1 & 1.000 & 0.814 & - & - & 0.663 & & \\
\hline ADMI2 & 0.882 & 0.778 & 0.075 & 11.703 & 0.605 & & \\
\hline ADMI3 & 1.044 & 0.827 & 0.085 & 12.222 & 0.685 & & \\
\hline
\end{tabular}

All $t$-values are significant at $\mathrm{P}<0.01$ level.

Four items (SQM2, SQM3, PRM2, and ADMI4) were dropped at the first analysis stage.

Discriminant validity refers to the extent to which a given construct is different from other constructs (John and Reve, 1982, p. 520). To test for discriminant validity, three approaches were used. The first approach was to perform a chi-square difference test on all pairs 
of constructs via CFA (Bagozzi and Phillips, 1982). For the test, it was necessary to develop two models in each pair of constructs: a constrained model and an unconstrained model. In the constrained model, a correlation parameter of a pair of constructs was constrained at 1 . On the other hand, in the unconstrained model, a correlation parameter was set to be free. A $\chi^{2}$ difference value was calculated by subtracting a $\chi^{2}$ of the unconstrained model from a $\chi^{2}$ of the constrained model. To verify discriminant validity, the $\chi^{2}$ difference value should be greater than 3.84 (Liang and Chen, 2009; Kim, 2009). CFA was run on 38 pairs of constructs twice. The $\chi^{2}$ difference values ranged from 4.135 to 41.859 (See Table 11). This result indicates that constructs exhibit strong discriminant validity.

Table 11. Discriminant validity assessment using a $\chi^{2}$ difference

\begin{tabular}{lcccccc}
\hline \multirow{2}{*}{$\begin{array}{l}\text { Pair of } \\
\text { constructs }\end{array}$} & \multicolumn{2}{c}{ Constrained model (Corr. $=1$ ) } & \multicolumn{2}{c}{ Unconstrained model (Corr. = free) } & \multicolumn{2}{c}{ Difference } \\
\cline { 2 - 7 } & $\chi^{2}$ & $\mathrm{df}$ & $\chi^{2}$ & $\mathrm{df}$ & $\Delta \chi^{2}$ (df = $)$ & Sig. \\
\hline QM Practices & & & & & & \\
MAL - TRA & 67.683 & 27 & 45.341 & 26 & 22.342 & $\mathrm{p}<0.05$ \\
MAL - EMR & 87.801 & 35 & 58.606 & 34 & 29.195 & $\mathrm{p}<0.05$ \\
MAL - SQM & 99.679 & 35 & 75.436 & 34 & 24.243 & $\mathrm{p}<0.05$ \\
MAL - CUR & 70.173 & 35 & 48.613 & 34 & 21.560 & $\mathrm{p}<0.05$ \\
MAL - QDR & 77.075 & 35 & 47.663 & 34 & 29.412 & $\mathrm{p}<0.05$ \\
MAL - PSD & 63.385 & 35 & 49.009 & 34 & 14.376 & $\mathrm{p}<0.05$ \\
MAL - PRM & 83.046 & 27 & 41.187 & 26 & 41.859 & $\mathrm{p}<0.05$ \\
TRA - EMR & 46.293 & 14 & 20.427 & 13 & 25.866 & $\mathrm{p}<0.05$ \\
TRA - SQM & 59.855 & 14 & 36.888 & 13 & 22.967 & $\mathrm{p}<0.05$ \\
TRA - CUR & 46.217 & 14 & 22.172 & 13 & 24.045 & $\mathrm{p}<0.05$ \\
TRA - QDR & 33.214 & 14 & 22.559 & 13 & 10.655 & $\mathrm{p}<0.05$ \\
TRA - PSD & 37.930 & 14 & 22.331 & 13 & 15.599 & $\mathrm{p}<0.05$ \\
TRA - PRM & 31.654 & 9 & 8.946 & 8 & 22.708 & $\mathrm{p}<0.05$ \\
EMR - SQM & 67.866 & 20 & 45.723 & 19 & 22.143 & $\mathrm{p}<0.05$ \\
EMR - CUR & 54.381 & 20 & 23.591 & 19 & 30.790 & $\mathrm{p}<0.05$ \\
EMR - QDR & 48.526 & 20 & 34.570 & 19 & 13.956 & $\mathrm{p}<0.05$ \\
EMR - PSD & 51.119 & 20 & 38.967 & 19 & 12.152 & $\mathrm{p}<0.05$
\end{tabular}




\begin{tabular}{lccccrc}
\hline Pair of & Constrained model (Corr. $=1$ ) & \multicolumn{2}{c}{ Unconstrained model (Corr. = free) } & \multicolumn{2}{c}{ Difference } \\
\cline { 2 - 7 } constructs & $\chi^{2}$ & $\mathrm{df}$ & $\chi^{2}$ & $\mathrm{df}$ & $\Delta \chi^{2}$ (df = $)$ & Sig. \\
\hline EMR - PRM & 44.984 & 14 & 20.591 & 13 & 24.393 & $\mathrm{p}<0.05$ \\
SQM - CUR & 94.443 & 20 & 76.555 & 19 & 17.888 & $\mathrm{p}<0.05$ \\
SQM - QDR & 51.702 & 20 & 42.111 & 19 & 9.591 & $\mathrm{p}<0.05$ \\
SQM - PSD & 60.002 & 20 & 52.807 & 19 & 7.195 & $\mathrm{p}<0.05$ \\
SQM - PRM & 61.360 & 14 & 47.662 & 13 & 13.698 & $\mathrm{p}<0.05$ \\
CUR - QDR & 49.542 & 20 & 37.044 & 19 & 12.498 & $\mathrm{p}<0.05$ \\
CUR - PSD & 46.457 & 20 & 28.372 & 19 & 18.085 & $\mathrm{p}<0.05$ \\
CUR - PRM & 54.922 & 14 & 21.782 & 13 & 33.140 & $\mathrm{p}<0.05$ \\
QDR - PSD & 41.534 & 20 & 37.305 & 19 & 4.229 & $\mathrm{p}<0.05$ \\
QDR - PRM & 35.776 & 14 & 27.620 & 13 & 8.156 & $\mathrm{p}<0.05$ \\
PSD - PRM & 30.787 & 14 & 23.152 & 13 & 7.635 & $\mathrm{p}<0.05$ \\
Innovation & & & & & & \\
RPDI - IPDI & 134.251 & 27 & 130.116 & 26 & 4.135 & $\mathrm{p}<0.05$ \\
RPDI - RPCI & 46.226 & 20 & 38.991 & 19 & 7.235 & $\mathrm{p}<0.05$ \\
RPDI - IPCI & 66.792 & 20 & 42.450 & 19 & 24.342 & $\mathrm{p}<0.05$ \\
RPDI - ADMI & 49.271 & 20 & 37.857 & 19 & 11.414 & $\mathrm{p}<0.05$ \\
IPDI - RPCI & 60.544 & 14 & 46.002 & 13 & 14.542 & $\mathrm{p}<0.05$ \\
IPDI - IPCI & 53.839 & 14 & 42.012 & 13 & 11.827 & $\mathrm{p}<0.05$ \\
IPDI - ADMI & 67.316 & 14 & 51.658 & 13 & 15.658 & $\mathrm{p}<0.05$ \\
RPCI - IPCI & 44.412 & 9 & 34.669 & 8 & 9.743 & $\mathrm{p}<0.05$ \\
RPCI - ADMI & 20.722 & 9 & 15.068 & 8 & 5.654 & $\mathrm{p}<0.05$ \\
IPCI - ADMI & 23.865 & 9 & 8.170 & 8 & 15.695 & $\mathrm{p}<0.05$ \\
\hline
\end{tabular}

The critical value: $\Delta \chi^{2}(\Delta \mathrm{df}=1)>3.84$ (Boyer and Hult, 2005, a)

Alternatively, the second approach for testing discriminant validity was to compare the Cronbach's $\alpha$ of a construct and its correlations with other constructs (Kaynak, 2003). According to a rule of thumb, discriminant validity can be achieved if the Cronbach's $\alpha$ is greater than the correlations (Sila and Ebrahimpour, 2005). It was found that Cronbach's $\alpha$ values are greater than correlations (See Table 12). The third approach, proposed by Fornell and Larcker (1981), is to compare the average variance extracted (AVE) and the squared correlation between any two constructs. To establish discriminant validity, a value of the AVE should be greater than a value of the squared correlation (Fornell and Larcker, 1981; Batra and Sinha, 2000). Table 12 shows 
that values of AVE are considered acceptable. Thus, the analysis of measurement models demonstrates that measures used in this study are reliable, unidimensional, and valid.

Table 12. Discriminant validity assessment using Cronbach's $\alpha$ and AVE

\begin{tabular}{lllllllllllllllr}
\hline Variables & 1 & 2 & 3 & 4 & 5 & 6 & 7 & 8 & 9 & 10 & 11 & 12 & 13 & $\alpha^{*}$ & AVE** \\
\hline 1. MAL & 1.00 & & & & & & & & & & & & & 0.889 & 0.584 \\
2. TRA & 0.54 & 1.00 & & & & & & & & & & & & 0.863 & 0.685 \\
3. EMR & 0.52 & 0.70 & 1.00 & & & & & & & & & & & 0.848 & 0.586 \\
4. SQM & 0.34 & 0.46 & 0.55 & 1.00 & & & & & & & & & & 0.855 & 0.607 \\
5. CUR & 0.39 & 0.47 & 0.46 & 0.38 & 1.00 & & & & & & & & & 0.867 & 0.625 \\
6. QDR & 0.34 & 0.73 & 0.76 & 0.57 & 0.51 & 1.00 & & & & & & & & 0.886 & 0.661 \\
7. PSD & 0.51 & 0.62 & 0.74 & 0.58 & 0.42 & 0.72 & 1.00 & & & & & & & 0.892 & 0.680 \\
8. PRM & 0.26 & 0.58 & 0.66 & 0.57 & 0.29 & 0.73 & 0.71 & 1.00 & & & & & & 0.792 & 0.564 \\
9. RPDI & 0.20 & 0.32 & 0.25 & 0.21 & 0.17 & 0.34 & 0.37 & 0.26 & 1.00 & & & & & 0.932 & 0.739 \\
10. IPDI & 0.31 & 0.26 & 0.41 & 0.30 & 0.22 & 0.31 & 0.43 & 0.46 & 0.38 & 1.00 & & & & 0.934 & 0.742 \\
11. RPCI & 0.28 & 0.24 & 0.38 & 0.21 & 0.10 & 0.29 & 0.34 & 0.31 & 0.32 & 0.28 & 1.00 & & & 0.876 & 0.705 \\
12. IPCI & 0.22 & 0.36 & 0.54 & 0.42 & 0.20 & 0.46 & 0.51 & 0.65 & 0.15 & 0.37 & 0.37 & 1.00 & & 0.890 & 0.733 \\
13. ADMI & 0.39 & 0.45 & 0.43 & 0.24 & 0.20 & 0.41 & 0.47 & 0.52 & 0.30 & 0.29 & 0.45 & 0.34 & 1.00 & 0.848 & 0.651 \\
\hline
\end{tabular}

*: Cronbach's $\alpha$

**: Average variance extracted (AVE)

\subsection{Hypotheses testing}

This section presents the results of the hypothesis testing. Research findings will be described focusing on two main issues: the relationship between QM practices and innovation and the interaction effects of moderating variables. Figure 4 shows a final structural model. 


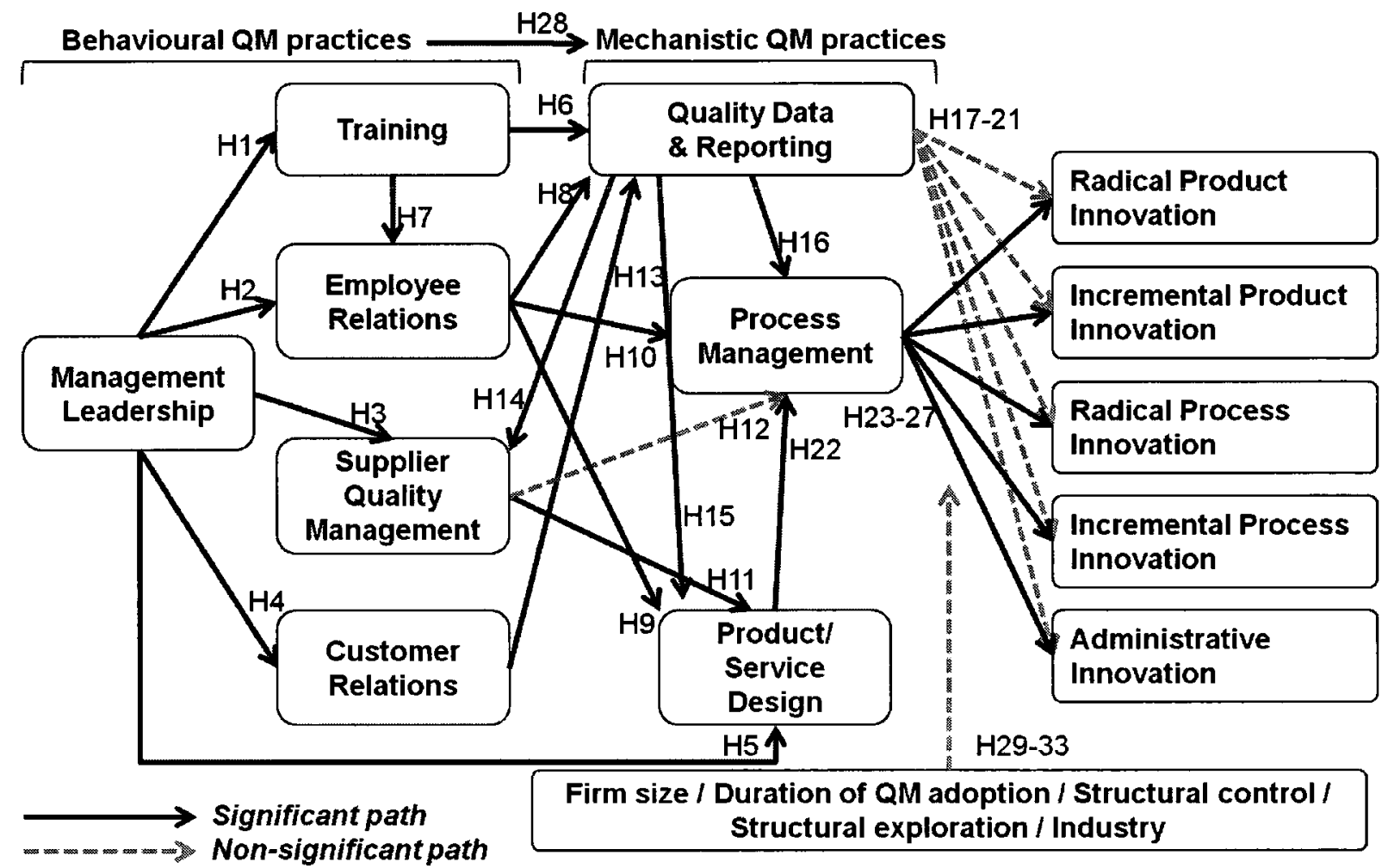

Hypotheses were tested using a latent variable model that included both latent variables and observed variables. Unlike the path analysis that assumes no measurement error, the latent variable model helps researchers not only to identify prediction error and measurement error, but also to accurately evaluate constructs and phenomena (Sila and Ebrahimpour, 2005). LISREL, using the maximum likelihood estimation, was employed to estimate coefficient and t-statistics. The estimate coefficient, noted by gamma $(\gamma)$ and beta $(\beta)$, represents the relative strength of the structural relationships between variables, while the $t$-statistic is a criterion to accept or reject a hypothesis (Gefen et al., 2000). The gamma $(\gamma)$ is related to paths linking an exogenous latent variable to an endogenous latent variable, while the beta $(\beta)$ is associated with paths connecting 
an endogenous latent variable to another endogenous latent variable. The $t$-value greater than 1.96 is significant at the $95 \%$ significance level, whereas the $t$-value greater than 2.58 is significant at the $99 \%$ significance level (Kaynak, 2003).

Tables 13 and 14 indicate the results of the tests of the relationship between QM practices and innovation. Overall results indicate 21 hypotheses were supported at the $95 \%$ or 99\% significance level. The goodness of fit indices shows that the structural model fits the data: $\mathrm{CFI}=0.98 ; \mathrm{RMSEA}=0.043 ; \chi^{2} / \mathrm{df}=1714 / 1197=1.43 ; \mathrm{NFI}=0.94 ;$ and $\mathrm{NNFI}=0.98$. It should be noted that all hypotheses related to management leadership (H1 - H5) were supported: between management leadership and training $(\gamma=0.45 ; t$-value $=7.03)$; between management leadership and employee relations $(\gamma=0.14 ; t$-value $=2.37)$; between management leadership and supplier quality management $(\gamma=0.17 ; t$-value $=2.06)$; between management leadership and customer relations $(\gamma=0.43 ; t$-value $=5.54)$; and between management leadership and product/service design $(\gamma=0.18 ; t$-value $=2.82)$. Moreover, significant paths were found in relationships between other QM practices, such as between training and employee relations. These statistical significances supported the following hypotheses: H6, H7, H8, H9, H10, H11, H13, H14, H15, H16, and H22. Furthermore, the result showed that process management is a significant and direct predictor of five types of innovation, supporting $\mathrm{H} 23-\mathrm{H} 27$. Further, it was found that impact of process management varies with the type of innovation. The impact of process management is less in the case of radical product innovation (coefficient: 0.41 ), when compared to other types of innovation: incremental product innovation $(0.86)$, radical process innovation (0.79), incremental process innovation (1.06), and administrative innovation (0.81). In other words, effective process management positively impacts four types of innovation: incremental product innovation, radical process innovation, incremental process innovation, and 
administrative innovation to a greater extent. Moreover, it was found that non-significant relationships between quality data/reporting and five types of innovation did not support $\mathrm{H} 17$ H21. Supplier quality management was not significantly related to process management (Beta $\beta$ $=0.09 ; t$-value $=1.63)$ and did not support $\mathrm{H} 12$. 
Table 13. Analysis results of the structural model

\begin{tabular}{|c|c|c|c|}
\hline Path & Coefficient & $t$-value & Significance \\
\hline H 1. Management leadership $\rightarrow$ Training & 0.45 & 7.03 & Significant** \\
\hline H 2. Management leadership $\rightarrow$ Employee relations & 0.14 & 2.37 & Significant* \\
\hline H 3. Management leadership $\rightarrow$ Supplier quality management & 0.17 & 2.06 & Significant* \\
\hline H 4. Management leadership $\rightarrow$ Customer relations & 0.43 & 5.54 & Significant** \\
\hline H 5. Management leadership $\rightarrow$ Product/service design & 0.18 & 2.82 & Significant** \\
\hline H 6. Training $\rightarrow$ Quality data \& reporting & 0.38 & 3.81 & Significant** \\
\hline H 7. Training $\rightarrow$ Employee relations & 0.56 & 6.60 & Significant** \\
\hline H 8. Employee relations $\rightarrow$ Quality data \& reporting & 0.59 & 5.18 & Significant** \\
\hline H 9. Employee relations $\rightarrow$ Product/service design & 0.38 & 3.12 & Significant** \\
\hline H 10. Employee relations $\rightarrow$ Process management & 0.23 & 2.22 & Significant* \\
\hline H 11. Supplier quality management $\rightarrow$ Product/service design & 0.15 & 2.34 & Significant* \\
\hline H 12. Supplier quality management $\rightarrow$ Process management & 0.09 & 1.63 & Non-significant \\
\hline H 13. Customer relations $\rightarrow$ Quality data $\&$ reporting & 0.15 & 3.06 & Significant** \\
\hline H 14 . Quality data \& reporting $\rightarrow$ Supplier quality management & 0.56 & 6.09 & Significant** \\
\hline H 15 . Quality data \& reporting $\rightarrow$ Product/service design & 0.36 & 3.47 & Significant** \\
\hline H 16. Quality data \& reporting $\rightarrow$ Process management & 0.26 & 2.68 & Significant** \\
\hline H 17. Quality data \& reporting $\rightarrow$ Radical product innovation & 0.18 & 1.04 & Non-significant \\
\hline H 18. Quality data \& reporting $\rightarrow$ Incremental product innovation & -0.23 & -1.64 & Non-significant \\
\hline H 19. Quality data \& reporting $\rightarrow$ Radical process innovation & -0.16 & -0.92 & Non-significant \\
\hline H 20. Quality data \& reporting $\rightarrow$ Incremental process innovation & -0.17 & -1.16 & Non-significant \\
\hline H 21. Quality data \& reporting $\rightarrow$ Administrative innovation & -0.07 & -0.44 & Non-significant \\
\hline H 22. Product/service design $\rightarrow$ Process management & 0.27 & 3.41 & Significant** \\
\hline H 23. Process management $\rightarrow$ Radical product innovation & 0.41 & 1.97 & Significant* \\
\hline H 24. Process management $\rightarrow$ Incremental product innovation & 0.86 & 4.95 & Significant** \\
\hline H 25. Process management $\rightarrow$ Radical process innovation & 0.79 & 3.78 & Significant** \\
\hline H 26. Process management $\rightarrow$ Incremental process innovation & 1.06 & 5.76 & Significant** \\
\hline H 27. Process management $\rightarrow$ Administrative innovation & 0.81 & 4.38 & Significant** \\
\hline H 28. Behavioural QM practices $\rightarrow$ Mechanistic QM practices & 1.60 & 7.94 & Significant** \\
\hline
\end{tabular}

$* P<0.05: t$-value is greater than 1.96

${ }^{* *} P<0.01: t$-value is greater than 2.58 
Table 14. Results of hypothesis testing

\begin{tabular}{|c|c|}
\hline Hypothesis & Result \\
\hline H 1. Management leadership will be positively associated with training. & Supported \\
\hline H 2. Management leadership will be positively associated with employee relations. & Supported \\
\hline H 3. Management leadership will be positively associated with supplier quality management. & Supported \\
\hline H 4. Management leadership will be positively associated with customer relations. & Supported \\
\hline H 5. Management leadership will be positively associated with product/service design. & Supported \\
\hline H 6. Training will be positively associated with quality data \& reporting. & Supported \\
\hline H 7. Training will be positively associated with employee relations. & Supported \\
\hline H 8. Employee relations will be positively associated with quality data and reporting. & Supported \\
\hline H 9. Employee relations will be positively associated with product/service design. & Supported \\
\hline H 10. Employee relations will be positively associated with process management. & Supported \\
\hline H 11. Supplier quality management will be positively associated with product/service design. & Supported \\
\hline H 12. Supplier quality management will be positively associated with process management. & Not Supported \\
\hline H 13. Customer relations will be positively associated with quality data and reporting. & Supported \\
\hline H 14. Quality data \& reporting will be positively associated with supplier quality management. & Supported \\
\hline H 15. Quality data \& reporting will be positively associated with product/service design. & Supported \\
\hline H 16. Quality data \& reporting will be positively associated with process management. & Supported \\
\hline H 17. Quality data \& reporting will be positively associated with radical product innovation. & Not supported \\
\hline H 18 . Quality data \& reporting will be positively associated with incremental product innovation. & Not supported \\
\hline H 19. Quality data \& reporting will be positively associated with radical process innovation. & Not supported \\
\hline H 20. Quality data \& reporting will be positively associated with incremental process innovation. & Not supported \\
\hline H 21. Quality data \& reporting will be positively associated with administrative innovation. & Not supported \\
\hline H 22. Product/service design will be positively associated with process management. & Supported \\
\hline H 23. Process management will be positively associated with radical product innovation. & Supported \\
\hline H 24. Process management will be positively associated with incremental product innovation. & Supported \\
\hline H 25. Process management will be positively associated with radical process innovation. & Supported \\
\hline H 26. Process management will be positively associated with incremental process innovation. & Supported \\
\hline H 27. Process management will be positively associated with administrative innovation. & Supported \\
\hline H 28. Behavioural QM practices will be positively associated with mechanistic QM practices. & Supported \\
\hline H 29. Firm size will moderate the relationship between QM and innovation. & Not supported \\
\hline $\mathrm{H}$ 30. The duration of QM adoption will moderate the relationship between $\mathrm{QM}$ and innovation. & Not supported \\
\hline H 31. Structural control will moderate the relationship between QM and innovation. & Not supported \\
\hline H 32. Structural exploration will moderate the relationship between QM and innovation. & Not supported \\
\hline H 33. Industry will moderate the relationship between QM and innovation. & Not supported \\
\hline
\end{tabular}

To further explore the relationship between QM practices and innovation, indirect effects

were examined using LISREL. Table 15 shows the total effects and indirect effects of QM 
practices on innovation. One of the important findings was that QM practices have a significant and indirect impact on innovation. In particular, there were significant and indirect links among three QM practices (management leadership, training, and employee relations) and all types of innovation. Other QM practices (supplier quality management and customer relations) partially and indirectly related to innovation. Further, although there was no significant and direct relationship between quality data and reporting and innovation, quality data and reporting had a significantly direct and indirect effect on process management. Through process management, quality data and reporting indirectly influenced four types of innovation, such as incremental product innovation. Moreover, the indirect effects of quality data and reporting on innovation were positive and significant, while the direct effects of quality data and reporting on innovation were negative and insignificant. 


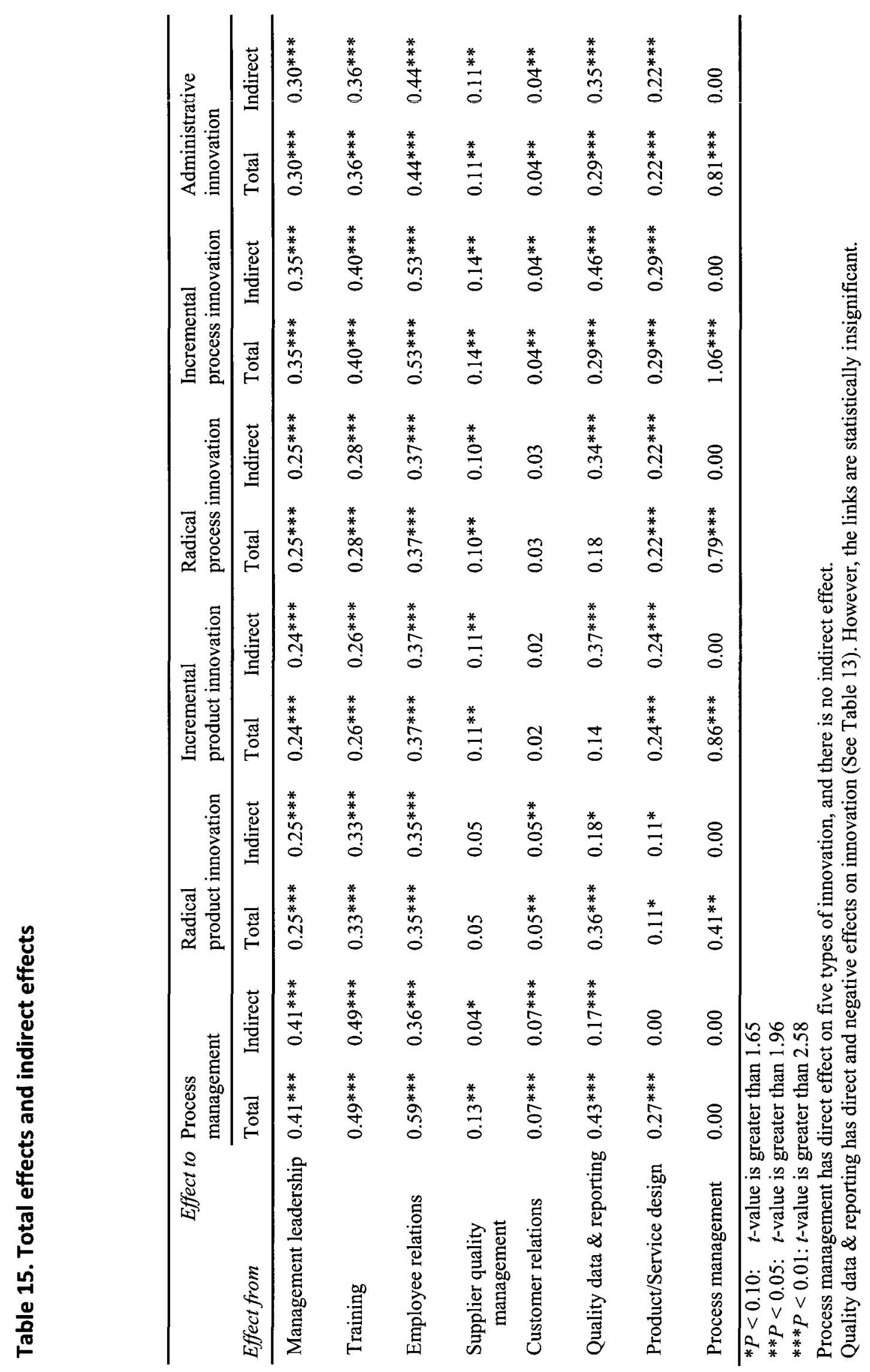


Additionally, paths, not included in a set of hypotheses, were examined to identify estimated coefficients and $t$-values. Although the literature reported no significant paths, it was interesting to test whether all $\mathrm{QM}$ practices have a direct impact on innovation. Thirty direct paths (e.g., management leadership $\rightarrow$ radical product innovation; customer relations $\rightarrow$ incremental process innovation) were added to the proposed structural model. The goodness of fit indices showed that the model has a good fit to the data: $\mathrm{CFI}=0.98 ; \mathrm{RMSEA}=0.042 ; \chi^{2} / \mathrm{df}=$ $1660.64 / 1167=1.42 ; \mathrm{NFI}=0.94 ;$ and NNFI $=0.98$. Four significant paths were additionally found to be statistically significant paths. These paths were as follows: between product/service design and radical product innovation $(\beta=0.41 ; t$-value $=2.29)$; between management leadership and radical process innovation $(\beta=0.25 ; t$-value $=2.03)$; between employee relations and incremental process innovation $(\beta=0.50 ; t$-value $=2.71)$; and between management leadership and administrative innovation $(\beta=0.28 ; t$-value $=2.57)$. These results are consistent with a few studies' findings. For example, using data from 252 firms, Feng et al. (2006) found a significant relationship between management leadership and innovation; and between employee relations and innovation. Hoang et al. (2006), in an empirical study of 102 machinery and instrument firms, concluded that there are significant relationships between employee relations and innovation; and between management leadership and innovation. Similarly, Perdomo-Ortiz et al. (2006), in an empirical study, confirmed a significant positive relationship between product/service design and innovation.

To test for the relationship between behavioural QM practices and mechanistic QM practices, a second-order model was developed (See Appendix H). The model was composed of two second-order factors: one for behavioural QM practices (management leadership, training, employee relations, supplier quality management, and customer relations) and the other for 
mechanistic QM practices (quality data/reporting, product/service design, and process management). For example, the second level factor represented a behavioural QM practice, which also included the first level sub-factors, such as management leadership. Further, the behavioural QM practice was considered to be an exogenous construct, while the mechanistic QM practice was regarded as an endogenous construct. A second-order factor analysis using LISREL was performed to examine the causal relationship between behavioural and mechanistic QM practices (Jöreskog and Sörbom, 1996; Marsh and Hocevar, 1988). The goodness of fit indices demonstrated that the model fit the data very well: $\mathrm{CFI}=0.99 ; \mathrm{RMSEA}=0.039 ; \chi^{2} / \mathrm{df}=$ $625.89 / 455=1.38 ; \mathrm{NFI}=0.99 ;$ and NNFI $=0.99$. The estimate coefficient for the path between behavioural QM practices and mechanistic QM practices was statistically significant $(\gamma=3.20$ and $t$-value 3.76). Thus, the hypothesis (H28) was supported.

To test for the interaction effects of moderating variables, a multi-group analysis (also called a multi-sample analysis) using LISREL was performed. The analysis aimed at expanding the research findings of the proposed model by examining whether a covariance of a variable is equal for different groups (Jöreskog and Sörbom, 1996). A two-stage approach was employed. First, the sample was divided into two groups in terms of each moderating variable: high technology industry vs. low technology industry; small and medium-sized company vs. largesized company; adoption for less than three years vs. adoption for more than three years; high control structure vs. low control structure; and high exploration structure vs. low exploration structure.

The classification of high vs. low technology industry was based on classifications proposed by Kaynak and Hartley (2005), who found that high technology firms operate mainly in the following seven industries: primary metal manufacturing; machinery manufacturing; 
transportation equipment manufacturing; chemical manufacturing; fabricated metal product manufacturing; computer and electronic product manufacturing; and electrical equipment, appliance and component manufacturing. High technology firms refer to organizations that allocate heavy resources to research and development and produce products or services that have a short life-cycle in high uncertain environment (Qian \& $\mathrm{Li}, 2003$ ).

Further, small- and medium-sized companies employ up to 500 workers, while the largesized companies employ more than 500 (Debus, 2005). The classification of the QM adoption period was related to whether a company has adopted the ISO 9001 certification less than three years or more than three years (Powell, 1996; Zadry and Yusof, 2006). Based on guidance proposed by Douglas and Judge (2001), organizational structure was split into two sub-features: structural control and structural exploration. Again, structural control was divided into high control structure and low control structure, whereas the exploration structure was split into high exploration structure and low exploration structure (Douglas and Judge, 2001). As data for the organizational structure was collected using multiple questions on a seven-point Likert-type scale, respondents' scores were averaged first and grouped into two groups: a low group and a high group. With respect to the structural control, the high control group scored from 1 to 4 , while the low control group scored more than 4 to 7 . In contrast, in terms of the structural exploration, the high exploration group scored more than 4 to 7 , while the low exploration group scored from 1 to 4 .

In the second-stage for exploring interaction effects, a proposed structural model was tested separately in each group to identify a parameter estimate of critical paths (e.g., process management $\rightarrow$ administrative innovation; process management $\rightarrow$ incremental process innovation). This study focused on five paths that show direct relationships between process 
management and five types of innovation. This is because process management is considered to be the most significant practice that directly leads to innovation. Figure 5 shows a structural model focusing on the five paths. 


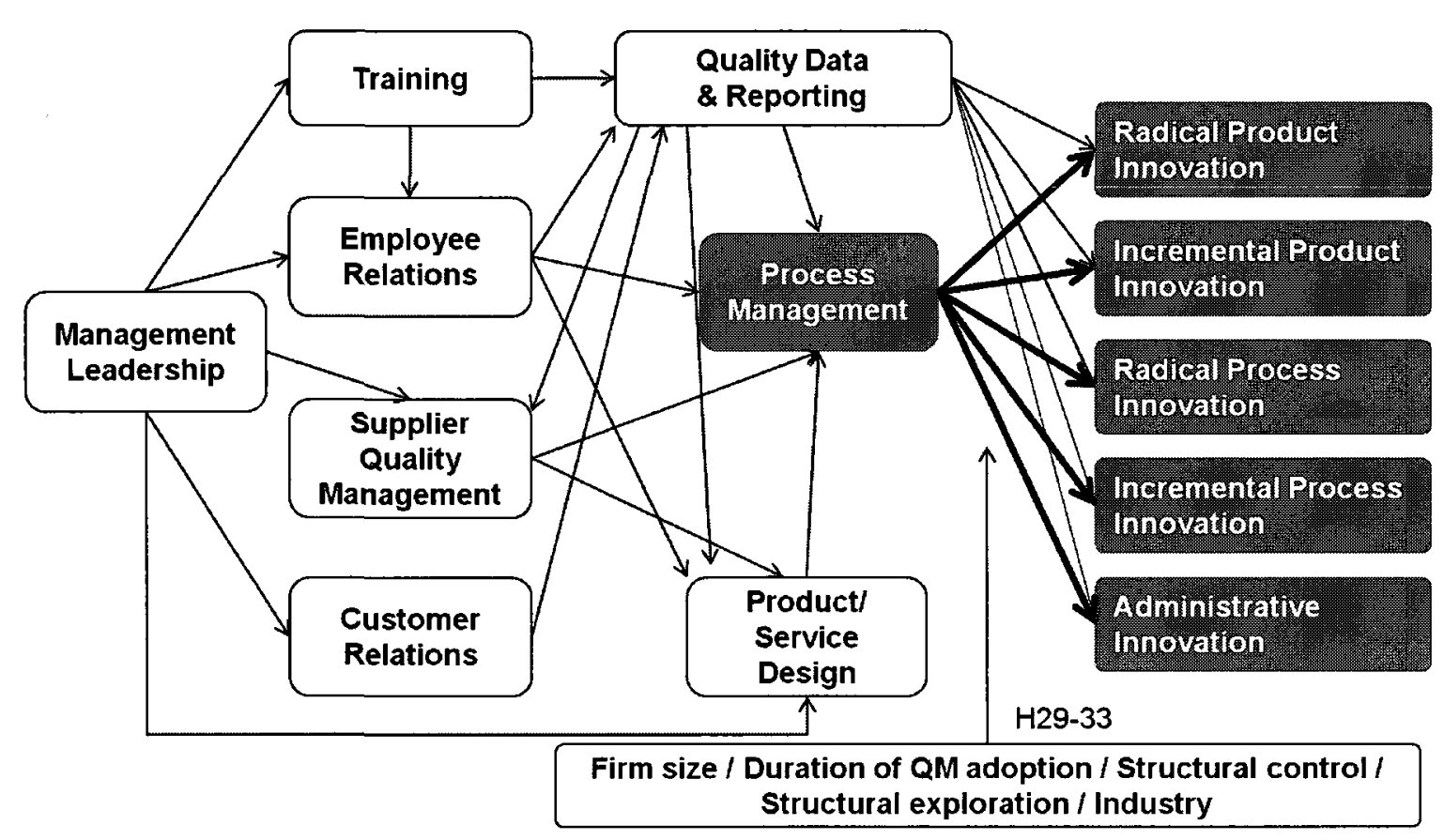

Next, to examine equality constraints between two groups, an unconstrained model and an equality constrained model were developed (Jöreskog and Sörbom, 1996). The unconstrained model estimated all hypothesized paths freely, while the equality constrained model specified a single path to equality across groups (Brockman et al., 2006; Neill, 2009). To interpret analysis results, a difference of $\chi^{2}$ values of both models was compared. According to the literature, the interaction effect of a moderating variable is significant at the 0.05 level if the difference of $\chi^{2}$ values is 3.84 or greater (Neill, 2009; Brockman et al., 2006).

Table 16 shows the analysis results of the multi-group analysis. The differences of $\chi^{2}$ between unconstrained models and equality constrained models ranged from 0 to 3.06 . Most $\chi^{2}$ values were less than 3.84 . Hypotheses 29 - 33 were not supported since the hypotheses are not 
significant at the $95 \%$ or $99 \%$ significance level. It can be interpreted that five moderating variables (firm size, the duration of QM adoption, structural control, structural exploration, and industry) do not have interaction effects on the relationship between QM practices and innovation. To fully explore the differences between groups, parameter estimates of five paths were individually investigated. One of the most important findings was that process management is a significant predictor of innovation in various groups. For instance, process management was significantly related to radical product innovation in both groups: companies that had adopted QM for up to three years and companies that had adopted QM for more than three years. Similarly, the path linking process management to incremental product innovation was statistically significant in these groups: high control and low control groups; high exploration and low exploration groups; and high technology and low technology industries. Based on these analysis results, managerial implications will be discussed in the next section. 


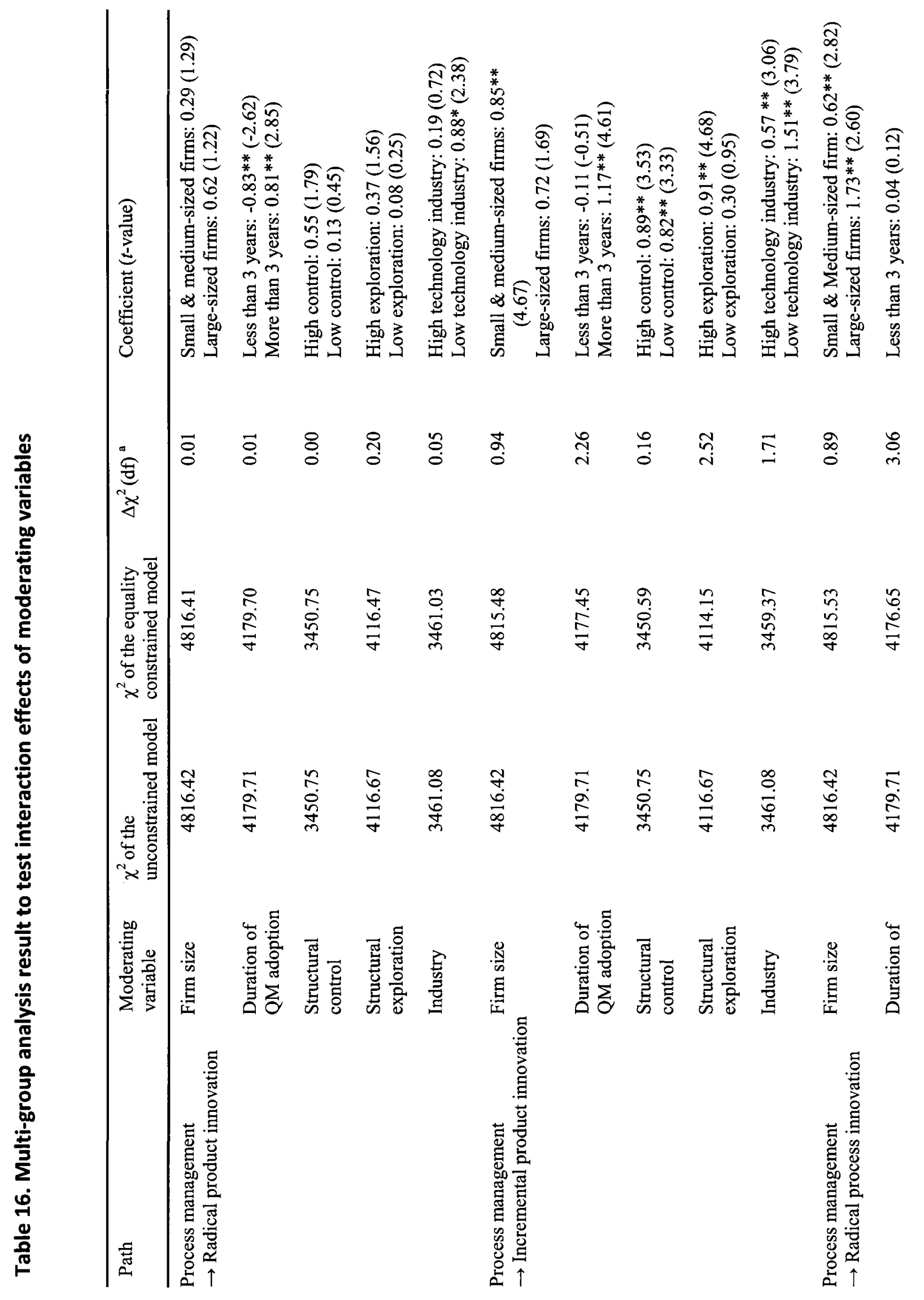




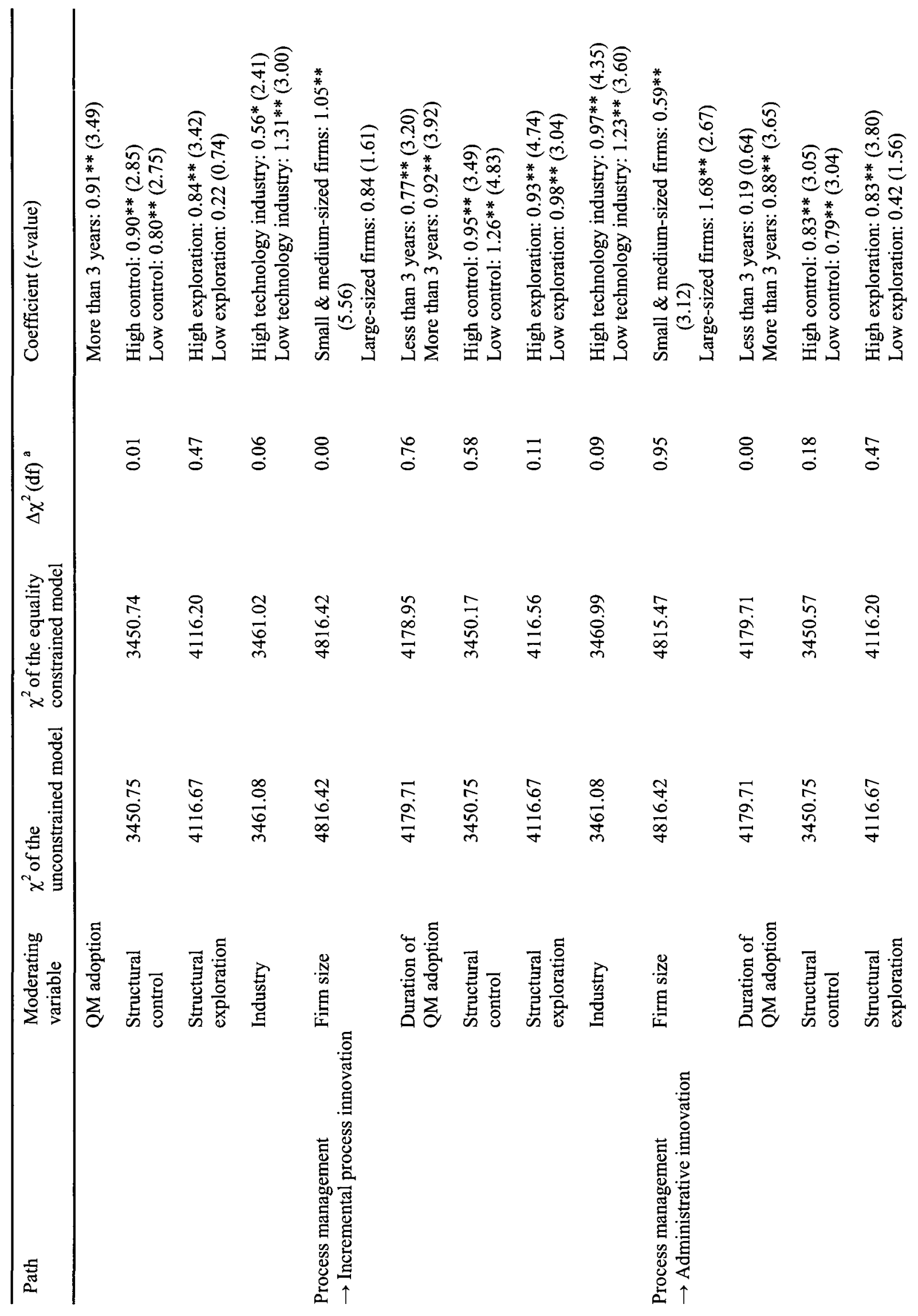

엄 


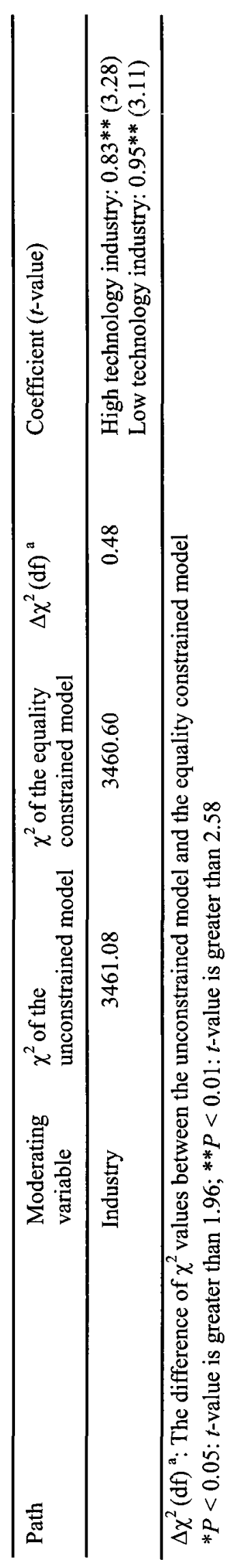

ฐ 


\section{Discussion and implications}

This study explores the contribution of QM practices to innovation through an empirical analysis. The analysis demonstrates strong support for the relationship between QM practices and innovation. The results of the latent variable model analysis and the multi-group analysis using LISREL indicate that 22 out of 33 hypotheses are supported. The supported hypotheses clearly show how QM practices through process management have statistically significant direct or indirect effects on performance. Moreover, there is no significant and direct relationship between supplier quality management and process management. This finding is consistent with those of other studies (e.g., Flynn et al., 1995; Sila and Ebrahimpour, 2005). An additional test of indirect effects, however, demonstrates that supplier quality management also has an indirect and significant effect on innovation. Similarly, while five hypotheses related to quality data and reporting are not supported, the analysis of indirect and total effects indicates that quality data and reporting is significantly associated with process management, impacting innovation indirectly. Hypotheses related to moderating variables are not supported, indicating that there is no interaction effect of the moderating variables on the relationship between QM practices and innovation. This analysis leads to three important findings and managerial implications.

The first finding is that QM practices have significant direct or indirect effects on innovation. The impacts of QM practices could be achieved if an organization implements a set of $\mathrm{QM}$ practices, not just a single or a few $\mathrm{QM}$ practices. This is because $\mathrm{QM}$ practices are interrelated to each other. For instance, training is significantly related to quality data and reporting, whereas quality data and reporting influences product/service design and process 
management. This finding is consistent with those of earlier studies. Using data from $130 \mathrm{R} \& D$ divisions of manufacturing firms, Prajogo and Hong (2008) found that there is a significant and positive relationship between a set of QM practices and product innovation. Similarly, MartinezCosta and Martinez-Lorente (2008), in a study of 451 manufacturing and non-manufacturing firms, found a positive and significant relationship between QM practices and product and process innovation. In an empirical study of 407 plants in the automobile industry, Ahire and Ravichandran (2001) underscored that QM should be implemented in an integrated fashion, not a cherry-picking manner. Similarly, Kaynak (2003), in a study of 214 manufacturing and service companies, found that a set of QM practices are significantly associated with performance. As Kaynak (2003) pointed out, the validation of the interdependence of QM practices should be emphasized to correctly understand the effects of QM practices on performance.

One implication of this finding is that top management should encourage employees to understand the causal relationship among QM practices and implement the practices in a comprehensive manner. Further, it will be useful for companies to identify the current status and develop strategies to improve some weaknesses by using the causal map. For example, to improve organizational capabilities for quality data and reporting, a company might invest in providing its employees with various training programs, working to motivate employee involvement in QM activities and establishing a close relationship with its customers. Therefore, investments in key practices may allow a company to efficiently improve its performance.

The second finding is that management leadership and process management should be considered as the most important practices in fostering innovation. This study shows that management leadership is a significant predictor of other QM practices and innovation. The analysis result indicates that management leadership has a direct effect on five other practices: 
training, employee relations, supplier quality management, customer relations, and product/service design. Management leadership is also positively and indirectly related to innovation. One interpretation is that management leadership plays a key role in implementing QM and producing innovation. Moreover, this study confirms a positive and direct role for process management in improving innovation. The analysis result shows that process management mediates the effects of QM practices (quality data and reporting, employee relations, supplier quality management, and product/service design) on five types of innovation. In particular, it was found that impact of process management varies with the type of innovation. The impact of process management is less in the case of radical product innovation, when compared to other types of innovation: incremental product innovation, radical process innovation, incremental process innovation, and administrative innovation. These findings are related to those of prior research. For example, Flynn et al. (1995), in a study of 42 manufacturing plants, reported that top management support is significantly related to customer relationship, supplier relationship, workforce management, work attitude, and product design process. Flynn et al. (1995) also found a significant relationship between process management and performance. Similarly, Hoang et al. (2006), in a study of 204 manufacturing and service companies, concluded that management leadership and process management showed significant and positive impacts on innovation.

Further, the results indicate that behavioural practices (e.g., leadership and employee relations) are significantly associated with mechanistic practices (e.g., process management and product/service design). A possible interpretation for this finding is that the success of TQM is based on a solid foundation of the behavioural aspects of QM practices (Zaho et al., 2004). It can be argued that developing the behavioural QM practices is a starting point in achieving 
innovation. This argument is supported by current studies. In an empirical study of 252 firms, Feng et al. (2006) found that the behavioural practices are significantly related to innovation. Hoang et al. (2006), based on their empirical study in 204 manufacturing and service firms, showed a statistical evidence for supporting the relationship between the behavioural practices (e.g., leadership and people management) and innovation.

One implication of these findings is that a company should devote attention to developing two practices: management leadership and process management. While management leadership is a baseline and a main foundation for enhancing other QM practices, process management has a direct effect on various types of innovation. Without top management and managers' commitment, it would be difficult to have an appropriate environment for generating the mechanistic practices. Similarly, to create innovation radically or incrementally, it may be imperative for companies to invest in the improvement of organizational processes. This suggestion will provide guidance for a company when investing its resources and changing its strategies.

The third finding is that the impacts of QM practices on innovation are not dependent on contextual features: firm size, the duration of QM adoption, structural control, structural exploration, and industry. Operations management researchers produced inconsistent findings of these aspects on the effectiveness of QM. While proponents of QM argued that the performance of QM can be universally available in any type of organization, some researchers found that the benefits of QM are contingent on the organizational context (e.g., Powell, 1995; Sousa and Voss, 2002). The findings of this study, however, demonstrate that there is no statistically significant difference in companies that have different contexts. However, the findings in this study would not mean that contextual factors are not important when implementing QM. Instead, one 
plausible explanation is that organizational efforts and attention might be more important to innovation than the organizational context. The finding of this study is consistent with findings of earlier empirical studies. For instance, Sila (2007), in a study of 302 manufacturing and service companies, found no evidence to support the argument that the relationship between QM and performance is context-dependent.

One implication of these findings is that a company should understand that the contextual factors (e.g., the duration of adoption of QM or the type of industry) are not sufficient to generate the impacts of $\mathrm{QM}$ on innovation. Organizational efforts to continually improve processes and systems require more attention. For example, while a company adopted and implemented QM practices for more than three years, the company might fail to achieve performance unless the company makes an effort to continually improve QM practices. Similarly, many companies with a certified ISO 9001 quality management system do not achieve superior performance through adopting ISO 9001. This is because top management was not involved in the organizational efforts and employees considered ISO 9001 as a paper-driven tool that lacks flexibility in relation to other management systems (Hashem and Tann, 2007; Zeng et al., 2007). Therefore, a company may need to pay attention to its efforts and corresponding QM practices. 


\section{Conclusion and limitations}

This study examines how QM practices impact on innovation. Based on the extensive literature review, a theoretical model is proposed that contains eight QM practices and five types of innovation. To test the causal relationship, data were collected from a sample of 223 ISO 9001 certified manufacturing or service firms. The statistical analysis, using the SEM approach, shows that all QM practices are interrelated with each other, influencing innovation directly or indirectly. This study also demonstrates that management leadership is a triggering factor for the development of other practices, such as training. In particular, process management has a significant and direct effect on all types of innovation. To further expand the boundary of earlier studies, the interaction effect of moderating variables, such as firm size and industry, is examined. The analysis using the multi-group analysis indicates that there is no significant effect of the moderating variables on the relationship between $\mathrm{QM}$ and innovation.

A few limitations of this study should be recognized, providing researchers with future research opportunities. Respondents for this study are ISO 9001 certified companies. The companies fit the research purpose because they are familiar with terminologies and concepts of QM practices. However, other QM intensive companies, which were awarded quality improvement awards such as the MBNQA or the EFQA, might have been left out of this study. It would be promising to replicate this research using data collected from companies that had been awarded the MBNQA or the EFQA but are not ISO 9001 certified. A second limitation is the use of cross-sectional data. Although the research is focused on examining the impact of QM on innovation across various organizations, it would be valuable to conduct a longitudinal study within organizations. This attempt would verify the finding of this research and improve 
understanding of the relationship of QM to innovation. While this study collected data based on respondents' perceptual judgment, considering their performance within a company, there is little attempt to compare their achievements with other competitors in a similar industry. There is also no quantitative measurement item to evaluate innovation. Though this study adopts measurement items from the literature, future researchers need to develop more objective and comprehensive measurement items for extending this research.

Despite these limitations, this study contributes to the development of the literature in the following five ways. First, it helps academics and practitioners understand how and why QM practices lead to innovation. Earlier studies answered "which QM practice is related to innovation" not "how QM practice leads to innovation." In other words, earlier studies were limited to simply identifying a list of QM practices that were related to innovation. Such a narrow view might be a reason for producing inconsistent findings about the impacts of $\mathrm{QM}$ on innovation. Unlike the previous studies, this study investigates linkages among QM practices and clearly shows the casual relationship of how a QM practice interacts with other QM practices to finally lead to innovation.

Second, this study provides empirical evidence about the relationship between behavioural QM practices and mechanistic QM practices. The literature calls for more research on the relationship (Sousa and Voss, 2002; Rahman, 2004). However, there is a lack of theory development underlying the correlation (e.g., Powell 1995; Feng et al., 2006; Samson and Terziovski, 1999; Hoang et al., 2006). To expand the current knowledge, this study examines the relationship and concludes that behavioural QM practices have a direct effect on mechanistic QM practices. This will allow practitioners and academics to understand why behavioural QM 
practices should be considered as foundational to implement mechanistic QM practices and how mechanistic QM practices can be generated through behavioural QM practices.

Third, this study makes a significant contribution to enhancing a better understanding of the relationship between QM practices and various types of innovation. This study examines the links between QM practices and five different types of innovation, such as radical incremental product innovation and administrative innovation. It is essential to explore the multidimensional aspects of innovation because for companies to achieve a sustainable competitive advantage, they need to understand the multiple types of innovation and balance between innovation efforts for existing customers and emerging ones (Tushman and O'Reilly, 1996; Grover et al., 2007; Corso et al., 2007; March, 1991). Theoretical support for this argument can be found in the literature - the relative imbalance between the innovative capabilities is negatively related to organizational performance (e.g., He and Wong, 2004; Baker and Sinkula, 2007; Danneels, 2004).

Fourth, this study expands the boundaries of previous studies by exploring the interaction effects of contextual variables, such as industry and firm size. In the operations management literature, researchers devoted little attention to examine the contextual factors (Nair, 2006; Sousa and Voss, 2002). However, understanding the moderating variables is very useful in highlighting the importance of QM practices in different situations. For instance, a service company might argue that its poor QM performance is caused by contextual factors. The company still regards QM as a management tool only for manufacturing companies. However, the findings of this study demonstrate that there is no significant interaction effect of the moderating variables in companies that are in different industries, have different number of employees, have different organizational structures, or adopted QM for a different duration. This 
result provides empirical evidence for supporting the argument that any type of company can achieve better performance using quality-based tools and concepts.

Finally, this study contributes to the literature on innovation by providing a comparison framework for radical, incremental, and administrative innovations. The extant literature has put little emphasis on describing the characteristics of the types of innovation in such depth. In this study, the characteristics are analyzed in terms of various dimensions, such as an objective, a level of change, and an output. The attempt will enable managers to understand features of innovation and efficiently manage a specific type of innovation. For example, managers can understand that an organic structure and a bottom-up approach are required to generate radical innovation, whereas a mechanistic structure and a bottom-up approach are needed to produce incremental innovation. Similarly, it will be helpful for managers to identify what level of risks they should take for creating different types of innovation; what kind of output of innovation will be expected. 


\section{Appendixes}

\section{Appendix A. Research model of Kaynak (2003)}

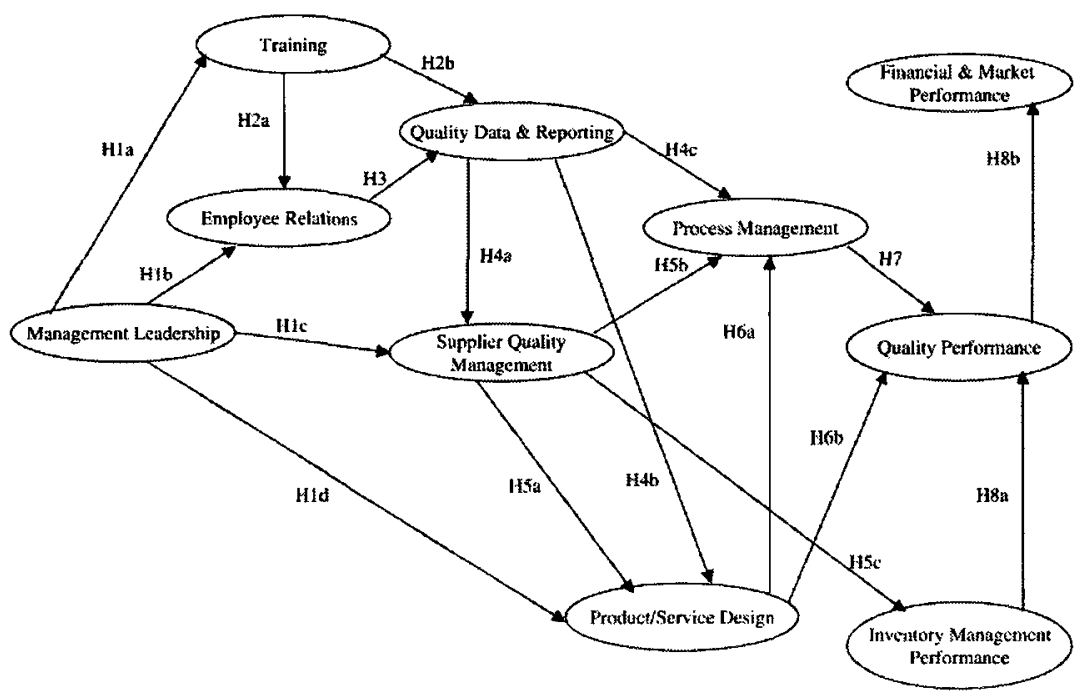


Appendix B. Variables and measures

\begin{tabular}{|c|c|}
\hline Variables & Measures \\
\hline QM Practices & Please indicate the level of the following items in your organization over the past 3 years. \\
\hline $\begin{array}{l}\text { Management } \\
\text { leadership }\end{array}$ & (adapted from Kaynak, 2003; Saraph et al., 1989) \\
\hline MAL 1 & $\begin{array}{l}\text { - Our top management (top organization executive and major department heads) evaluates } \\
\text { quality performance. }\end{array}$ \\
\hline MAL 2 & - Our department heads participate in the quality improvement process. \\
\hline MAL 3 & - Our top management has objectives for quality performance. \\
\hline MAL 4 & - Our top management has laid down a comprehensive goal-setting process for quality. \\
\hline MAL 5 & - Quality issues are reviewed in organizational top management meetings. \\
\hline MAL 6 & - Our top management considers quality improvement as a way to increase profits. \\
\hline Training & (adapted from Kaynak, 2003; Saraph et al., 1989) \\
\hline TAL 1 & $\begin{array}{l}\text { - Our organization provides employees with specific work skills training (technical and } \\
\text { vocational). }\end{array}$ \\
\hline TAL 2 & - Our organization provides employees with quality-related training. \\
\hline TAL 3 & - Our organization provides managers and supervisors with quality-related training. \\
\hline $\begin{array}{l}\text { Employee } \\
\text { relations }\end{array}$ & (adapted from Kaynak, 2003; Saraph et al., 1989) \\
\hline EMR 1 & - Our organization provides employees with feedback on their quality performance. \\
\hline EMR 2 & - Hourly/non-supervisory employees participate in quality decisions. \\
\hline EMR 3 & - Building quality awareness among employees is ongoing. \\
\hline EMR 4 & - Employees recognize superior quality performance. \\
\hline $\begin{array}{l}\text { Supplier quality } \\
\text { management }\end{array}$ & (adapted from Kaynak, 2003; Saraph et al., 1989) \\
\hline SQM 1 & - Our organization maintains long-term relationships with suppliers. \\
\hline SQM 2 & $\begin{array}{l}\text { Our organization has reduced the number of suppliers since implementing quality } \\
\text { management and/or JIT purchasing. }\end{array}$ \\
\hline SQM 3 & $\begin{array}{l}\text { - Our organization selects suppliers based on quality rather than price or delivery schedule } \\
\text { in order to improve organizational performance. }\end{array}$ \\
\hline SQM 4 & $\begin{array}{l}\text { Our organization evaluates suppliers according to quality, delivery performance, and } \\
\text { price, in order to improve organizational performance. }\end{array}$ \\
\hline SQM 5 & - Our organization has a thorough supplier rating system. \\
\hline SQM 6 & - Our suppliers are involved in our product/service development process. \\
\hline $\begin{array}{l}\text { Customer } \\
\text { relations }\end{array}$ & (adapted from Flynn et al., 1995; Zu et al., 2008) \\
\hline CUR 1 & - We frequently are in close contact with our customers. \\
\hline CUR 2 & - Our employees know our customers. \\
\hline CUR 3 & - Our customers give us feedback on quality and delivery performance. \\
\hline CUR 4 & - Our customers visit our office or workplace. \\
\hline $\begin{array}{l}\text { Quality data and } \\
\text { reporting }\end{array}$ & (adapted from Kaynak, 2003; Saraph et al., 1989) \\
\hline QDR 1 & $\begin{array}{l}\text { Quality data (for example, error rates, defect rates, scrap, and defects) is available in our } \\
\text { organization. }\end{array}$ \\
\hline QDR 2 & - Such quality data is timely. \\
\hline QDR 3 & $\begin{array}{l}\text { - Such quality data (for example, cost of quality, defects, errors, scrap, etc.) is used as a } \\
\text { tool to manage quality. }\end{array}$ \\
\hline
\end{tabular}




\begin{tabular}{|c|c|}
\hline Variables & Measures \\
\hline QDR 4 & $\begin{array}{l}\text { - Quality procedures are available to ensure the reliability and improvement of data } \\
\text { gathering. }\end{array}$ \\
\hline $\begin{array}{l}\text { Product/service } \\
\text { design }\end{array}$ & (adapted from Kaynak, 2003; Saraph et al., 1989) \\
\hline PSD 1 & $\begin{array}{l}\text { - Our organization conducts a thorough review of new product/service design before the } \\
\text { product/service is produced and marketed. }\end{array}$ \\
\hline PSD 2 & - Our departments fully participate in the product/service development process. \\
\hline PSD 3 & $\begin{array}{l}\text { The quality of new products/services is emphasized in relation to cost or schedule } \\
\text { objectives. }\end{array}$ \\
\hline PSD 4 & - Productivity is considered during the product/service design process. \\
\hline $\begin{array}{l}\text { Process } \\
\text { management }\end{array}$ & (adapted from Kaynak, 2003; Saraph et al., 1989) \\
\hline PRM 1 & - Inspection, review, or checking of work is automated. \\
\hline PRM 2 & - We usually meet the production schedule everyday. \\
\hline PRM 3 & - Our work processes are automated. \\
\hline PRM 4 & $\begin{array}{l}\text { - Quality techniques (e.g., statistical techniques) are used in order to reduce variance in } \\
\text { processes. }\end{array}$ \\
\hline Innovation & Please indicate the level of the following items over the past 3 years in your organization. \\
\hline $\begin{array}{l}\text { Radical product } \\
\text { innovation }\end{array}$ & (adapted from Herrmann, et al., 2007) \\
\hline RPDI 1 & - Our new products differ substantially from our existing products. \\
\hline RPDI 2 & $\begin{array}{l}\text { We introduce radical product innovations into the market more frequently than our } \\
\text { competitors. }\end{array}$ \\
\hline RPDI 3 & $\begin{array}{l}\text { - Our percentage of radical product innovations in the product range is significantly higher } \\
\text { compared to the competition. }\end{array}$ \\
\hline RPDI 4 & - The percentage of total sales from radical product innovations is up substantially. \\
\hline RPDI 5 & - We are well known by our customers for radical product innovations. \\
\hline $\begin{array}{l}\text { Incremental } \\
\text { product } \\
\text { innovation }\end{array}$ & (adapted from Herrmann, et al., 2007; Valle and Vázquez-Bustelo, 2009) \\
\hline IPDI 1 & - Our new products differ slightly from our existing products. \\
\hline IPDI 2 & $\begin{array}{l}\text { - We introduce incremental product innovations into the market more frequently than our } \\
\text { competitors. }\end{array}$ \\
\hline IPDI 3 & $\begin{array}{l}\text { - Our percentage of incremental product innovations in the product range is significantly } \\
\text { higher compared to the competition. }\end{array}$ \\
\hline IPDI 4 & - The percentage of total sales from incremental product innovations is up substantially. \\
\hline IPDI 5 & - We are well known by our customers for incremental product innovations. \\
\hline $\begin{array}{l}\text { Radical process } \\
\text { innovation }\end{array}$ & (adapted from Reichstein and Salter, 2006; Huergo and Jaumandreu, 2004) \\
\hline RPCI 1 & $\begin{array}{l}\text { - Our organization has introduced new or significantly improved machinery and equipment } \\
\text { for producing products or services. }\end{array}$ \\
\hline RPCI 2 & $\begin{array}{l}\text { Our organization has introduced new or significantly modified productive processes for } \\
\text { producing products or services. }\end{array}$ \\
\hline RPCI 3 & $\begin{array}{l}\text { - Our organization has introduced new or significantly improved information technologies } \\
\text { for producing products or services. }\end{array}$ \\
\hline $\begin{array}{l}\text { Incremental } \\
\text { process } \\
\text { innovation }\end{array}$ & $\begin{array}{l}\text { (adapted from Reichstein and Salter, 2006; Huergo and Jaumandreu, 2004; Jansen et al., } \\
\text { 2006) }\end{array}$ \\
\hline IPCI 1 & ur organization introduced minor or incrementally improved machinery and equipment \\
\hline
\end{tabular}




\begin{tabular}{|c|c|}
\hline Variables & Measures \\
\hline IPCI 3 & $\begin{array}{l}\text { for producing products or services. } \\
\text { Our organization introduced minor or incrementally modified productive processes for } \\
\text { producing products or services. } \\
\text { Our organization introduced minor or incrementally improved information technologies } \\
\text { for producing products or services. }\end{array}$ \\
\hline $\begin{array}{l}\text { Administrative } \\
\text { innovation }\end{array}$ & (adapted from Weerawardena, 2003; Kimberly and Evanisko, 1981) \\
\hline ADMI 1 & $\begin{array}{l}\text { - Our organization implemented new or improved existing computer-based administrative } \\
\text { applications. }\end{array}$ \\
\hline ADMI 2 & $\begin{array}{l}\text { Our organization implemented new or improved existing employee reward/training } \\
\text { schemes. }\end{array}$ \\
\hline ADMI 3 & $\begin{array}{l}\text { Our organization implemented new or improved existing structures such as project team } \\
\text { or departmental structures, within or in-between existing structures. }\end{array}$ \\
\hline ADMI 4 & - Our organization obtained new financing sources. \\
\hline \multicolumn{2}{|l|}{$\begin{array}{l}\text { Moderating } \\
\text { variables }\end{array}$} \\
\hline Firm size & $\begin{array}{l}\text { (adapted from Lehman, 1986; Terziovski et al., 1997) } \\
\text { - How many employees do you have in your organization? Fewer than } 50 \text {; between } 50 \text { and } \\
500 \text {; over } 500 \text {. }\end{array}$ \\
\hline $\begin{array}{l}\text { The duration of } \\
\text { QM adoption }\end{array}$ & $\begin{array}{l}\text { (adapted from Powell, 1995) } \\
\text { - For how many years has your organization maintained the ISO } 9000 \text { certification? Less } \\
\text { than } 3 \text { years; more than } 3 \text { years; not applicable. }\end{array}$ \\
\hline $\begin{array}{l}\text { Organizational } \\
\text { structure - } \\
\text { Structural } \\
\text { exploration }\end{array}$ & $\begin{array}{l}\text { (adapted from Douglas and Judge, 2001) } \\
\text { Please indicate the extent of the following items apply in your organization. } 1 \text { represents the } \\
\text { first statement in each pair, and } 7 \text { represents the second statement, with } 4 \text { as the midpoint } \\
\text { between the two choices. } \\
\text { - Choice 1: Highly structured channels of communication and highly restricted access to } \\
\text { important financial and operating information. Choice 2: Open channels of } \\
\text { communication with important financial and operating information flowing quite freely } \\
\text { throughout the organization. } \\
\text { Choice 1: A strong emphasis on holding fast to true and tried management principles } \\
\text { regardless of any changes in business conditions. Choice } 2 \text { : A strong emphasis on } \\
\text { adapting freely to changing circumstances without too much concern for past practices. }\end{array}$ \\
\hline $\begin{array}{l}\text { Organizational } \\
\text { structure - } \\
\text { Structural control }\end{array}$ & $\begin{array}{l}\text { (adapted from Douglas and Judge, 2001) } \\
\text { - Choice 1: Strong emphasis on always getting personnel to follow the formally laid down } \\
\text { procedures. Choice 2: Strong emphasis on getting things done even if this means } \\
\text { disregarding formal procedures. } \\
\text { Choice 1: Tight formal control of most operations by means of sophisticated control and } \\
\text { information systems. Choice } 2 \text { : Loose, informal control; heavy dependence on informal } \\
\text { relationships and cooperation for getting work done. } \\
\text { Choice 1: Strong emphasis on getting line and staff personnel to adhere closely to formal } \\
\text { job descriptions. Choice 2: Strong tendency to let requirements of the situation and the } \\
\text { individual's personality define proper on-job behavior. }\end{array}$ \\
\hline Industry & $\begin{array}{l}\text { (adapted from Kaynak and Hatley, 2005) } \\
\text { What type of industry is your organization in? Service; Chemical manufacturing; Primary } \\
\text { metal manufacturing; Fabricated metal product manufacturing; Machinery } \\
\text { manufacturing; Computer and electronic product manufacturing; Transportation } \\
\text { equipment manufacturing; Electrical equipment, appliance, and component } \\
\text { manufacturing; Other. }\end{array}$ \\
\hline
\end{tabular}




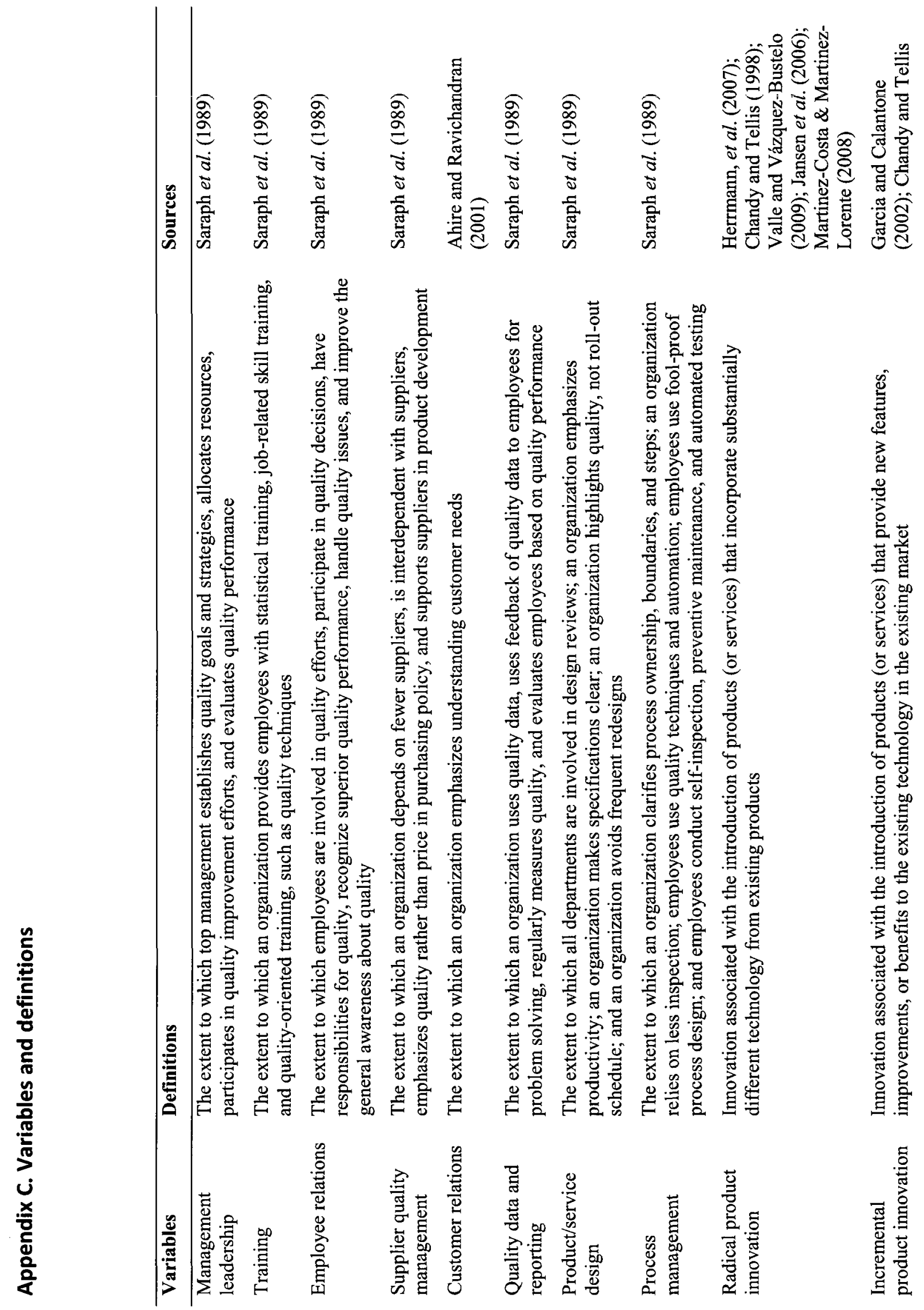




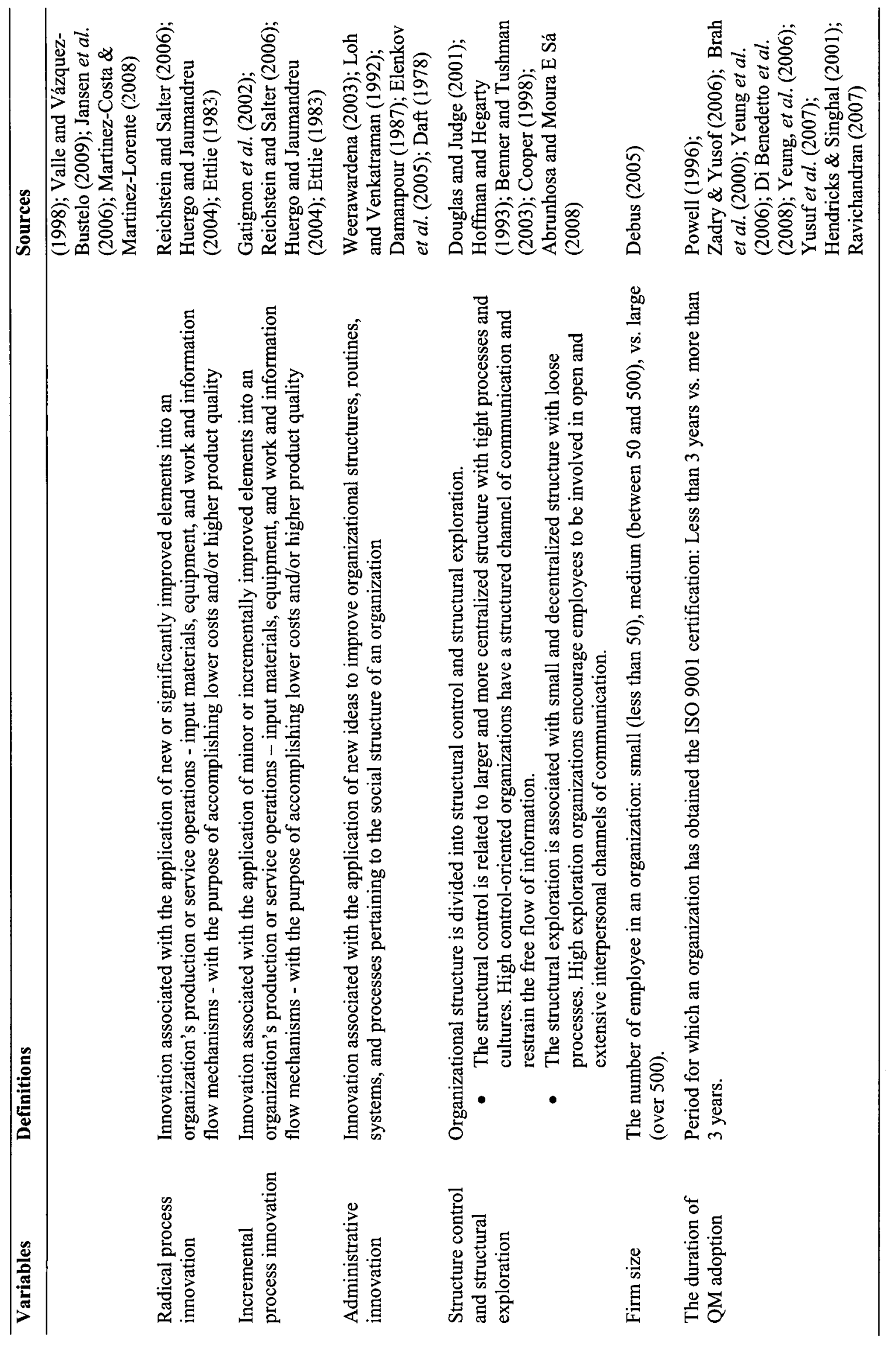


Appendix D. Result of exploratory factor analysis (EFA) for QM practices

\begin{tabular}{|c|c|c|c|c|c|c|c|c|}
\hline & \multicolumn{8}{|c|}{ Component } \\
\hline & 1 & 2 & 3 & 4 & 5 & 6 & 7 & 8 \\
\hline MAL1 & .815 & .088 & .147 & .132 & .136 & .033 & -.004 & .087 \\
\hline MAL2 & .713 & .128 & .167 & .081 & .226 & .068 & -.058 & .115 \\
\hline MAL3 & .841 & .108 & .103 & .160 & -.029 & .028 & .092 & .087 \\
\hline MAL4 & .804 & .049 & .041 & .031 & -.006 & .136 & .117 & .043 \\
\hline MAL5 & .761 & .137 & .133 & .009 & .188 & .039 & -.035 & .123 \\
\hline MAL6 & .601 & .082 & .160 & .069 & .237 & -.072 & .067 & .385 \\
\hline TRA1 & .159 & .170 & .178 & .153 & .102 & .301 & .107 & .709 \\
\hline TRA2 & .277 & .134 & .135 & .088 & .196 & .312 & .141 & .720 \\
\hline TRA3 & .271 & .155 & .142 & .154 & .242 & .154 & .228 & .730 \\
\hline EMR1 & .226 & .090 & .363 & .138 & .550 & .176 & .128 & .222 \\
\hline EMR2 & .114 & .143 & .211 & .083 & .717 & .140 & .189 & .132 \\
\hline EMR3 & .179 & .114 & .172 & .146 & .668 & .315 & .192 & .194 \\
\hline EMR4 & .241 & .163 & .138 & .227 & .755 & .197 & .128 & .096 \\
\hline SQM1 & .047 & .159 & .193 & .756 & .238 & .042 & .131 & .176 \\
\hline SQM4 & .020 & .101 & .208 & .856 & .187 & .051 & .019 & .143 \\
\hline SQM5 & .158 & .147 & .097 & .784 & .015 & .168 & .248 & .053 \\
\hline SQM6 & .268 & .061 & .092 & .644 & .044 & .283 & .193 & -.012 \\
\hline CUR1 & .160 & .830 & .069 & .114 & .131 & .134 & .106 & .131 \\
\hline CUR2 & .251 & .772 & -.071 & .114 & .099 & .198 & .054 & -.060 \\
\hline CUR3 & .136 & .812 & .213 & .062 & .105 & .087 & .022 & .163 \\
\hline CUR4 & -.008 & .795 & .136 & .114 & .061 & .035 & -.027 & .125 \\
\hline QDR1 & .149 & .315 & .283 & .194 & .209 & .554 & .271 & .185 \\
\hline QDR2 & .059 & .144 & .177 & .156 & .158 & .742 & .228 & .207 \\
\hline QDR3 & .049 & .169 & .286 & .134 & .288 & .718 & .080 & .203 \\
\hline QDR4 & .040 & .143 & .223 & .215 & .288 & .646 & .267 & .293 \\
\hline PSD1 & .233 & .143 & .707 & .243 & .181 & .190 & .218 & .112 \\
\hline PSD2 & .216 & .097 & .774 & .231 & .145 & .202 & .113 & .093 \\
\hline PSD3 & .199 & .134 & .714 & .174 & .189 & .230 & .258 & .157 \\
\hline PSD4 & .185 & .107 & .665 & .082 & .295 & .167 & .263 & .167 \\
\hline PRM1 & .040 & .106 & .266 & .099 & .202 & .160 & .744 & .199 \\
\hline PRM3 & -.020 & .011 & .221 & .184 & .107 & .153 & .789 & .077 \\
\hline PRM4 & .095 & .006 & .134 & .309 & .234 & .236 & .636 & .137 \\
\hline
\end{tabular}


Appendix E. Result of exploratory factor analysis (EFA) for Innovation

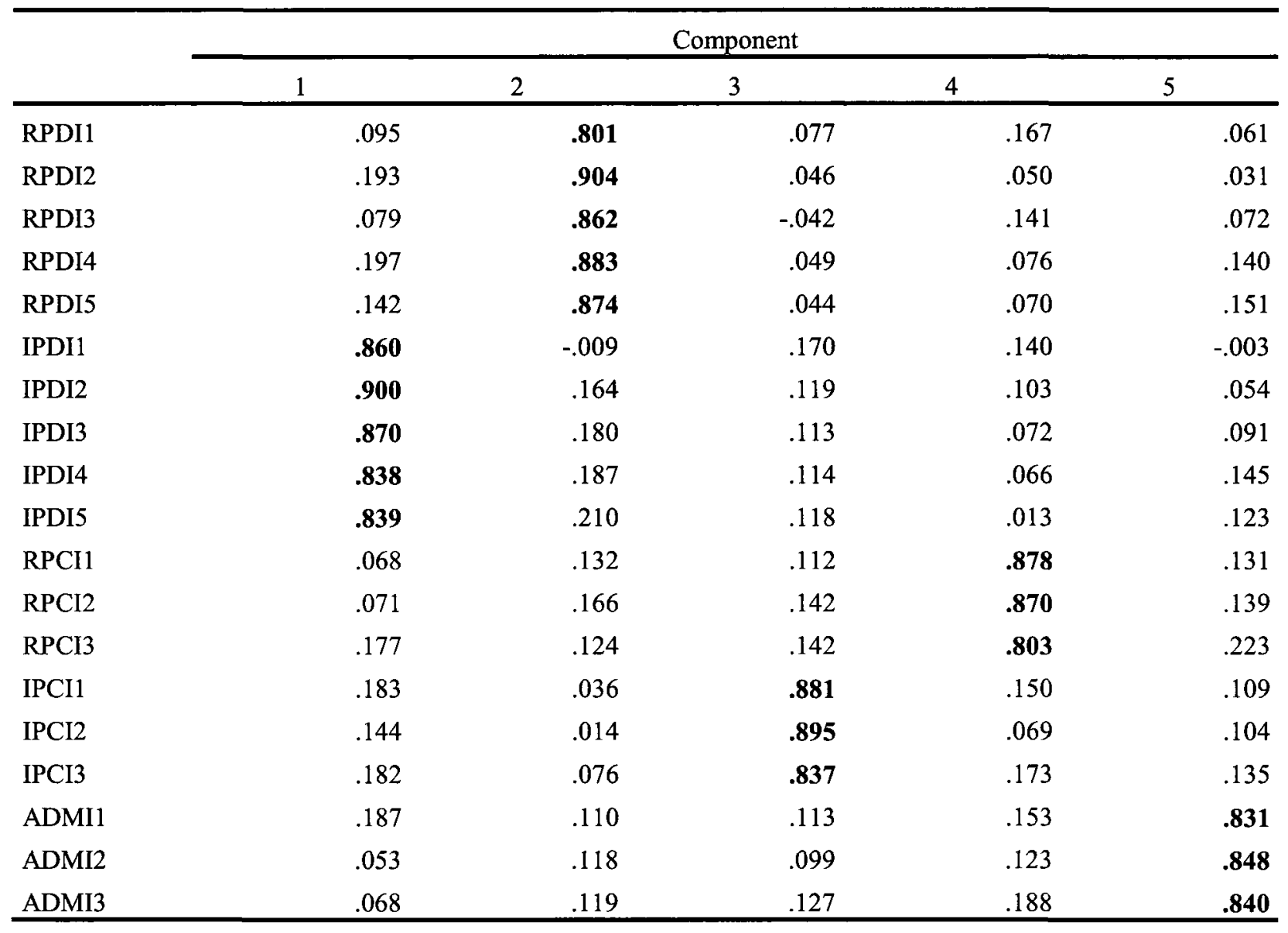




\section{Appendix F. Result of Confirmatory Factor Analysis (CFA) for each construct}

\begin{tabular}{lccccc}
\hline Construct & CFI & RMSEA & $\chi^{2} / \mathrm{df} *^{*}$ & NFI & NNFI \\
\hline Management leadership & 0.99 & 0.074 & 2.27 & 0.98 & 0.98 \\
Training & 1.00 & 0.000 & 0.00 & 1.00 & 1.00 \\
Employee relations & 0.99 & 0.077 & 2.45 & 0.99 & 0.98 \\
Supplier quality management & 1.00 & 0.000 & 0.02 & 1.00 & 1.00 \\
Customer relations & 1.00 & 0.000 & 0.28 & 1.00 & 1.00 \\
Quality data and reporting & 1.00 & 0.078 & 2.38 & 0.99 & 0.99 \\
Product and service design & 1.00 & 0.052 & 1.61 & 1.00 & 0.99 \\
Process management & 1.00 & 0.000 & 0.00 & 1.00 & 1.00 \\
Radical product innovation & 1.00 & 0.063 & 2.00 & 0.99 & 0.99 \\
Incremental product innovation & 1.00 & 0.069 & 2.21 & 0.99 & 0.99 \\
Radical product innovation & 1.00 & 0.000 & 0.00 & 1.00 & 1.00 \\
Incremental process innovation & 1.00 & 0.000 & 0.00 & 1.00 & 1.00 \\
Administrative innovation & 1.00 & 0.000 & 0.00 & 1.00 & 1.00 \\
\hline
\end{tabular}

$\chi^{2} / \mathrm{df}$ : Management leadership $(20.39 / 9=2.27) ;$ Employee relations $(4.90 / 2=2.45)$; Supplier quality management $(0.02 / 1=0.02)$; Customer relations $(0.28 / 1=0.28)$; Quality data and reporting $(4.75 / 2=2.38)$; Product and service design $(1.61 / 1=1.61)$; Radical product innovation $(7.98 / 4=2.00)$; Incremental product innovation $(8.85 / 4=2.21)$ 

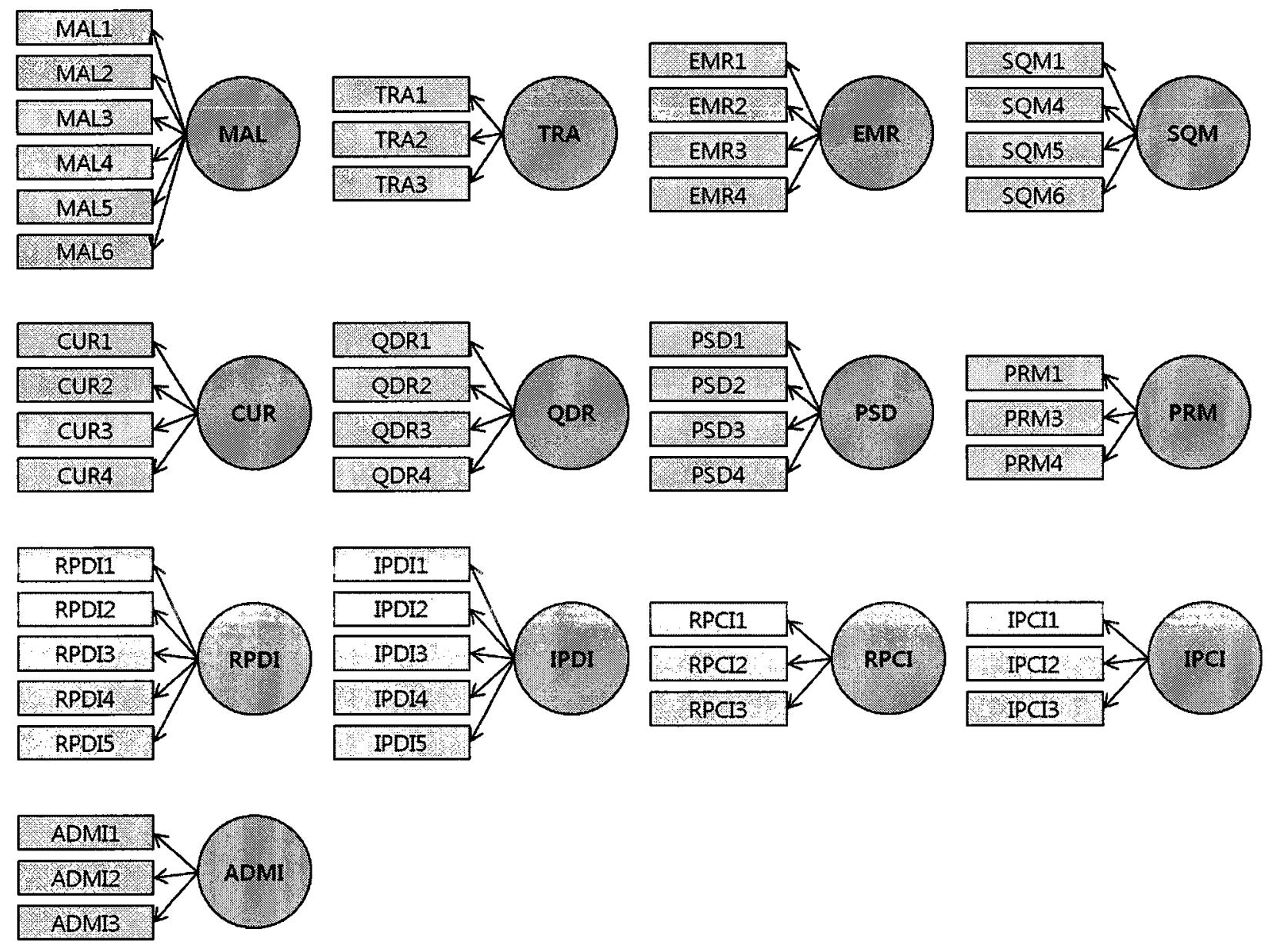


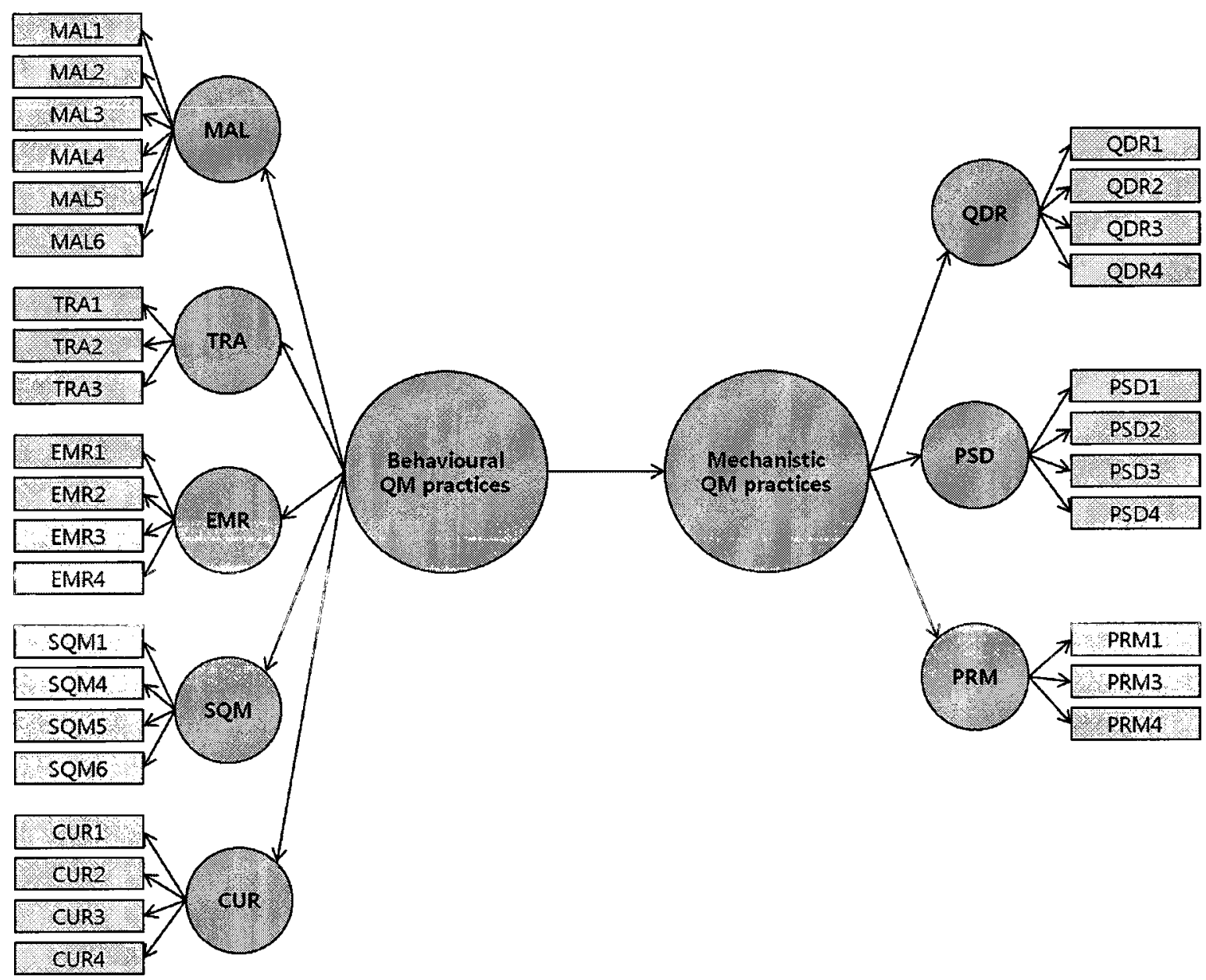




\section{References}

Abrunhosa, A., \& Moura E Sá, P. (2008). Are TQM principles supporting innovation in the Portuguese footwear industry? Technovation, 28(4), 208-221.

Ahire, S. L., \& Dreyfus, P. (2000). The impact of design management and process management on quality: an empirical examination. Journal of Operations Management, 18(5), 549575.

Ahire, S. L., \& Ravichandran, T. (2001). An innovation diffusion model of TQM implementation. IEEE Transactions on Engineering Management, 48(4), 445-464.

Ahire, S. L., Golhar, D. Y., \& Waller, M. A. (1996). Development and validation of TQM implementation constructs. Decision Sciences. 27 (1), 23-56.

Anderson, J. C. \& D. W. Gerbing. (1988). Structural equation modeling in practice: A review and recommended two-step approach. Psychological Bulletin, 103(3), 411-423.

Anderson, J. C., Rungtusanatham, M., \& Schroeder, R. G. (1994). A theory of quality management underlying the Deming management method. Academy of Management Review, 19(3), 472-509.

Anderson, J. C., Rungtusanatham, M., Schroeder, R. G., \& Devaraj, S. (1995). A path analytic model of a theory of quality management underlying the Deming management method: Preliminary empirical findings. Decision Sciences, 26(5), 637-658.

Armstrong, J. S., \& Overton, T. S. (1977). Estimating nonresponse bias in mail surveys. Journal of Marketing Research, 14(3), 396-402.

Bagozzi, R. P., \& Phillips, L. W. (1982). Representing and testing organizational theories: a holistic construal. Administrative Sciences Quarterly, 27 (3), 459-489.

Baker, W. E., \& Sinkula, J. M. (2007). Does market orientation facilitate balanced innovation programs? An organizational learning perspective. Journal of Product Innovation Management, 24(4), 316-334.

Barringer, B. R., \& Bluedorn, A. C. (1999). The Relationship between Corporate Entrepreneurship and Strategic Management. Strategic Management Journal, 20(5), 421444.

Batra, R., \& Sinha, I. (2000). Consumer-level factors moderating the success of private label brands, Journal of Retailing, 76(2), 175-191.

Becheikh, N., Landry, R., \& Amara, N. (2006). Lessons from innovation empirical studies in the manufacturing sector: A systematic review of the literature from 1993-2003.

Technovation, 26(5-6), 644-664. 
Benner, M. J., \& Tushman, M. L. (2003). Exploitation, exploration, and process management: The productivity dilemma revisited. The Academy of Management Review, 28(2), 238256.

Bentler, P. M., \& Bonett, D. G. (1980). Significance tests and goodness of fit in the analysis of covariance structures, Psychological Bulletin, 88, 588-606.

Besterfield, D. H., Besterfield-Michna, C., Besterfield, G. H., \& Besterfield-Sacre, M. (2003). Total quality management, Pearson Prentice Hall, New Jersey.

Bhuian, S. N., Menguc, B., \& Bell, S. J. (2005). Just entrepreneurial enough: the moderating effect of entrepreneurship on the relationship between market orientation and performance. Journal of Business Research, 58(1), 9-17.

Bollen, K. A. (1989). Structural equations with latent variables. Wiley, New York.

Bommer, M., \& Jalajas, D. S. (2004). Innovation sources of large and small technology-based firms. IEEE Transactions on engineering Management, 51(1), 13-18.

Bou, J. C., \& Beltrán, I. (2005). Total quality management, high-commitment human resource strategy and firm performance: an empirical study. Total Quality Management \& Business Excellence, 16(1), 71-86.

Boyer, K. K. \& Hult, G. T. M. (2005, a). Customer behavior in an online ordering application: A decision scoring model. Decision Sciences, 36(4), 569-598.

Boyer, K. K. \& Hult, G. T. M. (2005, b). Extending the supply chain: Integrating operations and marketing in the online grocery industry. Journal of Operations Management. 23(6). 642-661.

Brah, S. A., Li Wong, J., \& Rao, B. M. (2000). TQM and business performance in the service sector: a Singapore study. International Journal of Operations and Production Management, 20(11/12), 1293-1312.

Brinkerhoff, J. M. (2002). Assessing and improving partnership relationships and outcomes: a proposed framework. Evaluation and Program Planning, 25(3), 215-231.

Brockman, B. K., Becherer, R. C., \& Finch, J. H. (2006). Influences on an entrepreneur's perceived risk: The role of magnitude, likelihood, and risk propensity. Academy of Entrepreneurship Journal, 12(2), 107-126.

Broring, S., \& Herzog, P. (2008). Organising new business development: open innovation at Degussa. European Journal of Innovation Management, 11(3), 330-348.

Browne, M. W., \& Cudeck, R. (1993). Alternative ways of assessing model fit. In K. A. Bollen \& J. S. Long (Eds.), Testing structural equation models (pp. 136-162). Newbury Park, CA.

Burke, R. J. (1999). Managerial feedback, organizational values and service quality. Managing Service Quality, 9(1), 53-57. 
Byrne, B. M. (1998). Structural equation modeling with LISREL, PRELIS, and SIMPLIS: Basis concepts, application, and programming. Lawrence Erlbaum, Mahwah, New Jersey.

Carmines, E. G., \& McIver, J. P. (1981). Analyzing models with unobserved variables. In: Bohrnstedt, G.W., Borgatta, E.F. (Eds.), Social Measurement: Current Issues. Sage, Beverly Hills, CA, pp. 65-115.

Carr, A. S., \& Pearson, J. N. (1999). Strategically managed buyer-seller relationships and performance outcomes. Journal of Operations Management, 17 (5), 497-519.

Chandy, R. K., \& Tellis, G. J. (1998). Organizing for radical product innovation: the overlooked role of willingness to cannibalize. Journal of Marketing Research, 35(4), 474-487.

Chen, I. J., Paulraj, A., \& Lado, A. A. (2004). Strategic purchasing, supply management, and firm performance. Journal of Operations Management, 22(5), 505-523.

Chhabra, D., Sills, E., \& Rea, P. (2002). Tourist expenditures at heritage festivals. Event Management, 7(4), 221-230.

Choi, T. Y., \& Eboch, K. (1998). The TQM paradox: relations among TQM practices, plant performance, and customer satisfaction. Journal of Operations Management, 17(1), 5975 .

Claver, E., Llopis, J., Garcia, D., \& Molina, H. (1998). Organizational culture for innovation and new technological behavior. The Journal of High Technology Management Research, $9(1), 55-68$.

Cooper, J. R. (1998). A multidimensional approach to the adoption of innovation. Management Decision, 36(8), 493 - 502.

Corso, M., Pellegrini, L., \& Diotisalvi, V. (2007). Continuous and discontinuous innovation: overcoming the innovator dilemma. Creativity and Innovation Management, 16(4), 333347.

Curran P. J., West S. G., \& Finch J. F. (1996). The robustness of test statistics to nonnormality and specification error in confirmatory factor analysis. Psychological Methods, 1(1), 1629.

Daft, R. L. (1978). A dual-core model of organizational innovation. Academy of Management Journal, 21(2), 193-210.

Damanpour, F. (1987). The Adoption of Technological, Administrative, and Ancillary Innovations: Impact of Organizational Factors. Journal of Management, 13(4), 675- 688.

Damanpour, F. (1991). Organizational Innovation: A Meta-Analysis of Effects of Determinants and Moderators. The Academy of Management Journal, 34(3), 555-590.

Danneels, E. (2004). Disruptive technology reconsidered: A critique and research agenda. Journal of Product Innovation Management, 21(4), 246-258. 
De Propris, L. (2002). Types of innovation and inter-firm co-operation. Entrepreneurship \& Regional Development, 14(4), 337-353.

Debackere, K., Looy, B. V., \& Vliegen, J. (1997). A process view on managing quality during the creation of technical innovations: lessons from field research. $R \& D$ Management, 27(3), 197-211.

Debus, A. (2005). Small Business Profile: An Overview of Canada's Small and Mid-sized Business Sector. Canadian Federation of Independent Business.

Dellana, S. A., \& Wiebe, H. A. (1995). An exploration of Total Quality Management practices in U. S. R\&D organizations. Engineering Management Journal, 7(2), 23-29.

Di Benedetto, C. A., DeSarbo, W. S., \& Song, M. (2008). Strategic Capabilities and Radical Innovation: An Empirical Study in Three Countries. IEEE Transactions on Engineering Management, 55(3), 420-433.

Dooyoung, S., Kalinowski, J. G., \& El-Enein, G. (1998). Critical implementation issues in total quality management. SAM Advanced Management Journal, 63 (1), 10-14.

Douglas, T. J., \& Judge, W. Q. (2001). Total quality management implementation and competitive advantage: the role of structural control and exploration. Academy of Management Journal, 44 (1), 158-169.

Elenkov, D. S., Judge, W., \& Wright, P. (2005). Strategic leadership and executive innovation influence: an international multi-cluster comparative study. Strategic Management Journal, 26(7), 665-682.

Eng, Q. E., \& Yusof, S. (2003). A survey of TQM practices in the Malaysian electrical and electronic industry. Total Quality Management \& Business Excellence, 14(1), 63-77.

Ettlie, J. E. (1983). Organizational policy and innovation among suppliers to the food processing sector. Academy of Management Journal, 26(1), 27-44.

Evans, J. R. \& Lindsay, W. M. (2008). Managing for Quality and Performance Excellence, Thomson South-Western, Mason.

Feng, J., Prajogo, D. I., Tan, K. C., \& Sohal, A. S. (2006). The impact of TQM practices on performance: A comparative study between Australian and Singaporean organizations. European Journal of Innovation Management, 9(3), 269-278.

Flynn, B. B., Schroeder, R. G., \& Sakakibara, S. (1994). A framework for quality management research and an associated measurement instrument. Journal of Operations Management. 11(4), 339-366.

Flynn, B. B., Schroeder, R. G., \& Sakakibara, S. (1995). The impact of quality management practices on performance and competitive advantage. Decision Sciences, 26 (5), 659-691.

Fornell, C., \& Larcker, D. F. (1981). Evaluating structural equation models with unobservable variables and measurement error. Journal of Marketing Research, 18(1), 39-50. 
Frohlich (2002). Techniques for improving response rates in OM survey research. Journal of Operations Management, 20, 53-62.

Gaertner, G. H., Gaertner, K, N., \& Akinnusi, D. M. (1984). Environment, strategy, and the implementation of administrative change: The case of civil service reform. Academy of Management Journal, 27(3), 525-543.

Garcia, R., \& Calantone, R. (2002). A critical look at technological innovation typology and innovativeness terminology: a literature review. Journal of Product Innovation Management, 19(2), 110-132.

Gatewood, R. D. \& Field, H. S. (1990). Human Resource Selection, 2nd ed., The Dryden Press, Chicago, IL.

Gatignon, H., Tushman, M. L., Smith, W., \& Anderson, P. (2002). A structural approach to assessing innovation: Construct development of innovation locus, type, and characteristics. Management Science, 1103-1122.

Gefen, D., Straub, D. W., \& Boudreau, M. (2000). Structural equation modeling and regression: Guidelines for research practice. Communications of AIS, 4(7), 1-79.

Gerbing, D. W., \& Anderson, J. C. (1992). Monte Carlo evaluations of goodness of fit indices for structural equation models. Sociological Methods and Research, 21(3), 132-160.

Germain, R., \& Spears, N. (1999). Quality management and its relationships with organizational context and design. International Journal of Quality and Reliability Management, 16 (4), 371-391.

Goetsch, D. L., \& Davis, S. B. (2006). Quality management: Introduction to total quality management for production. Pearson Prentice Hall, New Jersey.

Green, S. G., Gavin, M. B., \& Aiman-Smith, L. (1995). Assessing a multidimensional measure of radical technologicalinnovation. IEEE Transactions on Engineering Management, 42(3), 203-214.

Grover, V., Purvis, R. L., \& Segars, A. H. (2007). Exploring Ambidextrous Innovation Tendencies in the Adoption of Telecommunications Technologies. IEEE Transactions on Engineering Management, 54(2), 268-285.

Hafeez, K., Malak, N., \& Abdelmeguid, H. (2006). A framework for TQM to achieve business excellence. Total Quality Management \& Business Excellence, 17(9), 1213-1229.

Hannan, M., \& Freeman, J. (1984). Structural inertia and organizational change. American Sociological Review, 49, 149-164.

Hashem, G., \& Tann, J. (2007). The Adoption of ISO 9000 Standards within the Egyptian Context: A Diffusion of Innovation Approach. Total Quality Management \& Business Excellence, 18(6), 631-652. 
He, Z. L., \& Wong, P. K. (2004). Exploration vs exploitation: an empirical test of the ambidexterity hypothesis. Organization Science, 15(4), 481-494.

Hendricks, K. B., \& Singhal, V. R. (2001). Firm characteristics, total quality management, and financial performance. Journal of Operations Management, 19(3), 269-285.

Herrmann, A., Gassmann, O., \& Eisert, U. (2007). An empirical study of the antecedents for radical product innovations and capabilities for transformation. Journal of Engineering and Technology Management, 24(1-2), 92-120.

Hoang, D. T., Igel, B., \& Laosirihongthong, T. (2006). The impact of total quality management on innovation: Findings from a developing country. International Journal of Quality and Reliability Management, 23(8-9), 1092-1117.

Hoffman, R. C., \& Hegarty, H. W. (1993). Top management influence on innovations: effects of executive characteristics and social culture. Journal of Management, 19(3), 549-574.

Hu, L., \& Bentler, P. M. (1999). Cutoff criteria for fit indexes in covariance structure analysis: Conventional criteria versus new alternatives. Structural Equation Modeling: $A$ Multidisciplinary Journal, 6(1), 1-55.

Huergo, E., \& Jaumandreu, J. (2004). Firms' age, process innovation and productivity growth. International Journal of Industrial Organization, 22(4), 541- 559.

Huiban, J., \& Bouhsina, Z. (1998). Innovation and the quality of labour factor: An empirical investigation in the French food industry. Small Business Economics, 10(4), 389-400.

Hult, G. T., Ketchen, D. J., \& Slater, S. F. (2004). Information processing, knowledge development, and strategic supply chain performance. Academy of Management Journal, 47(2), 241-253.

Hurmelinna-Laukkanen, P., Sainio, L. M., \& Jauhiainen, T. (2008). Appropriability regime for radical and incremental innovations. $R \& D$ Management, 38(3), 278-289.

Ibarra, H. (1993). Network centrality, power, and innovation involvement: Determinants of technical and administrative roles. Academy of Management Journal, 36(3), 471-501.

Idris, M. A., \& Zairi, M. (2006). Sustaining TQM: a synthesis of literature and proposed research framework. Total Quality Management \& Business Excellence, 17(9), 1245-1260.

ISO (2000). ISO 9001:2000 Quality Management Systems: Requirements, International Organization for Standerdization, Geneva.

Jansen, J., Van Den Bosch, F. A. J., \& Volberda, H. W. (2006). Exploratory innovation, exploitative innovation, and performance: effects of organizational antecedents and environmental moderators. Management Science, 52(11), 1661-1674.

John, G., \& Reve, T. (1982). The reliability and validity of key informant data from dyadic relationships in marketing channels. Journal of Marketing Research, 19(4), 517-524. 
Jöreskog, K. G., \& Sörbom, D. (1996). LISREL 8: User `s reference guide. Scientific Software International Inc, Chicago.

Kaynak, H. (2003). The relationship between total quality management practices and their effects on firm performance. Journal of Operations Management, 21(4), 405-435.

Kaynak, H., \& Hartley, J. L. (2005). Exploring quality management practices and high tech firm performance. Journal of High Technology Management Research, 16(2), 255-272.

Kerlinger, F. N., \& Lee, H. B. (2000). Foundations of behavioral research, Harcourt College Publisher, Orlando, FL.

Kim, S. W. (2009). An investigation on the direct and indirect effect of supply chain integration on firm performance. International Journal of Production Economics, 119, 328-346.

Kimberly, J. R., \& Evanisko, M. J. (1981). Organizational innovation: The influence of individual, organizational, and contextual factors on hospital adoption of technological and administrative innovations. Academy of Management Journal, 24(4), 689-713.

Kline, R. B. (2005). Principles and practices of structural equation modeling. The Guilford Press, New York

Knight, K. E. (1967). A descriptive model of the intra-firm innovation process. Journal of Business, 40(4), 478-496.

Koberg, C. S., Detienne, D. R., \& Heppard, K. A. (2003). An empirical test of environmental, organizational, and process factors affecting incremental and radical innovation. Journal of High Technology Management Research, 14(1), 21-45.

Lamb, G. E., \& Dale, B. G. (1994). Quality improvement in research and development: a study. Journal of Engineering Manufacture, 208(4), 253-257.

Lambert, D. M., Knemeyer, A. M., \& Gardner, J. T. (2004). Supply chain partnerships: model validation and implementation. Journal of Business Logistics, 25(2), 21-42.

Lehman, J. (1986). Organizational size and information system sophistication. Journal of Management Information Systems, 2(3), 78-86.

Leifer, R., Gina Colarelli, O. C., Rice, M., \& Gina Colarelli, O. C. (2001). Implementing radical innovation in mature firms: The role of hubs. The Academy of Management Executive, 15(3), 102-113.

Lemke, F., Goffin, K., \& Szwejczewski, M. (2003). Investigating the meaning of suppliermanufacturer partnerships. International Journal of Physical Distribution \& Logistics Management, 33(1), 12-35.

Li, C. R., Lin, C. J., \& Chu, C. P. (2008). The nature of market orientation and the ambidexterity of innovations. Management Decision, 46(7), 1002-1026.

Liang, C. J., \& Chen, H. J. (2009). A study of the impacts of website quality on customer relationship performance. Total Quality Management, 20(9), 971-988. 
Lloréns Montes, F. J., Ruiz Moreno, A., \& Garcı'a Morales, V. (2005). Influence of support leadership and teamwork cohesion on organizational learning, innovation and performance: an empirical examination, Technovation, 25(10), 1159-1172.

Loh, L., \& Venkatraman, N. (1992). Diffusion of Information Technology Outsourcing: Influence Sources and the Kodak Effect, Information Systems Research, 3(4), 334-358.

López-Mielgo, N., Montes-Peón, J. M., \& Vázquez-Ordás, C. J. (2009). Are quality and innovation management conflicting activities? Technovation. 29(8), 537-545.

Lovett, J. R. (1992). Doing the right things right, all the time. Research Technology Management, September/October, 35-38.

Maloni, M. J., \& Benton, W. C. (1997). Supply chain partnerships: Opportunities for operations research. European Journal of Operational Research, 101(3), 419-429.

Mandelbrot, B. (1967). The Variation of Some Other Speculative Prices, The Journal of Business, 40(4), 393-413.

March, J. G. (1991), Exploration and exploitation in organizational learning. Organization Science, 2(1), 71-87.

Martinez-Costa, M., \& Martinez-Lorente, A. R. (2008). Does quality management foster or hinder innovation? An empirical study of Spanish companies. Total Quality Management \& Business Excellence, 19(3), 209-221.

Mathur-De Vré, R. (2000). The scope and limitations of a QA system in research. Accreditation and Quality Assurance: Journal for Quality, Comparability and Reliability in Chemical Measurement, 5(1), 3-10.

May, C., \& Pearson, A. W. (1993). Total quality in R\&D, Journal of General Management, $18(3), 1-22$.

Mehra, S., Hoffman, J. M., \& Sirias, D. (2001). TQM as a management strategy for the next millennia. International Journal of Operations and Production Management, 21(5/6), 855-876.

Miller, R. (1994). Quality in research: an empirical study. Technovation, 14(6), 381-394.

Miller, R. (1995). Applying quality practices to R\&D. Research Technology Management, 38(2), 47-54.

Moguilnaia, N. A., Vershinin, K. V., Sweet, M. R., Spulber, O. I., De Souza, M. M., \& Narayanan, E. M. S. (2005). Innovation in power semiconductor industry: Past and future. IEEE Transactions on Engineering Management, 52(4), 429-439.

Mohr, J., \& Spekman, R. (1994). Characteristics of partnership success: Partnership attributes, communication behavior, and conflict resolution techniques. Strategic Management Journal, 15(2), 135-152. 
Mohrman, S. A., Tenkasi, R. V., Lawler, E. E., \& Ledford, G. E. (1995). Total quality management: practice and outcomes in the largest US firms. Employee Relations, 17 (3), $26-41$.

Montana, A. J. (1992), If it isn't perfect, make it better. Research Technology Management, July/August, 38-41.

Moors, E. H. M., \& Vergragt, P. J. (2002). Technology Choices for Sustainable Industrial Production: Transitions in Metal Making. International Journal of Innovation Management, 6(3), 277-299.

Motwani, J. G., Mahmoud, E., \& Rice, G. (1994). Quality practices of Indian organizations: An empirical analysis. International Journal of Quality and Reliability Management , 11(1), 38-52.

Moura E Sá, P., \& Abrunhosa, A. (2007). The role of TQM practices in technological innovation: the Portuguese footwear industry case. Total Quality Management \& Business Excellence, 18(1), 57-66.

Nair, A. (2006). Meta-analysis of the relationship between quality management practices and firm performance-implications for quality management theory development. Journal of Operations Management, 24(6), 948-975.

Neill, S. (2009). Decomposing the effects of organizational memory on marketing implementation. Marketing Letters, Springer Netherlands.

OECD. (2006). OECD Science, Technology and Industry Outlook 2006, Paris, France.

Pandey, S., \& Sharma, R. R. K. (2009). Organizational Factors for Exploration and Exploitation. Journal of Technology Management \& Innovation, 4(1), 48-58.

Park, S., Hartley, J. L., \& Wilson, D. (2001). Quality management practices and their relationship to buyer's supplier ratings: a study in the Korean automotive industry. Journal of Operations Management, 19(6), 695-712.

Patino, H., (1997). Applying total quality to R\&D at Coors Brewing Company. Research Technology Management, September-October, 40(5), 32-37.

Perdomo-Ortiz, J., González-Benito, J., \& Galende, J. (2006). Total quality management as a forerunner of business innovation capability. Technovation, 26(10), 1170-1185.

Podsakoff, P. M., \& Organ, D. W. (1986). Self-reports in organizational research: Problems and prospects. Journal of Management, 12(4), 531-544.

Powell, T. C. (1995). Total quality management as competitive advantage: a review and empirical study. Strategic Management Journal, 16(1), 15-37.

Prajogo, D. I., \& Hong, S. W. (2008). The effect of TQM on performance in R\&D environments: A perspective from South Korean firms. Technovation, 28(12), 855-863. 
Prajogo, D. I., \& Sohal, A. S. (2001). TQM and innovation: a literature review and research framework. Technovation, 21(9), 539-558.

Prajogo, D. I., \& Sohal, A. S. (2004). The multidimensionality of TQM practices in determining quality and innovation performance - an empirical examination. Technovation, 24(6), 443-453.

Prajogo, D. I., \& Sohal, A. S. (2006). The integration of TQM and technology/R\&D management in determining quality and innovation performance. Omega, 34(3), 296-312.

Qian, G., \& Li, L. (2003). Profitability of small and medium-sized enterprises in high-tech industries: the case of the biotechnology industry. Strategic Management Journal, 24(9), $881-887$.

Quazi, H. A., Jemangin, J., Kit, L. W., \& Kian, L. C. (1998). Critical factors in quality management and guidelines for self-assessment: the case of Singapore. Total Quality Management \& Business Excellence, 9(1), 35- 55.

Rahman, S. (2004). The future of TQM is past. Can TQM be resurrected? Total Quality Management \& Business Excellence, 15(4), 411-422.

Ravichandran, T. (2007). Swiftness and Intensity of Administrative Innovation Adoption: An Empirical Study of TQM in Information Systems. Decision Sciences, 31(3), 691 - 724.

Ravichandran, T., \& Rai, A. (2000). Quality Management in Systems Development: An Organizational System Perspective. MIS Quarterly, 24(3), 381-415.

Reger, R., Gustafson, L., Demarie, S., \& Mullane, J. (1994). Reframing the organization: why implementing total quality is easier said than done. Academy of Management Review, 19(3), 565-584.

Reichstein, T. and Salter, A. (2006). Investigating the sources of process innovation among UK manufacturing firms. Industrial and Corporate Change, 15(4), 653-682.

Reimann, C. W., \& Hertz, H. S. (1994). Understanding the important differences between the Malcolm Baldrige National Quality Award and ISO 9000 registration. Production and Operations Management, 3(3), 171-185.

Roth, P. L., \& Switzer, F. S. (1995). A Monte Carlo Analysis of Missing Data Techniques in a HRM Setting. Journal of Management, 21(5), 1003-1023.

Rothbard, N. P. (2001). Enriching or Depleting? The Dynamics of Engagement in Work and Family Roles. Administrative Science Quarterly, 46(4), 655-684.

Rothwell, R., \& Gardiner, P. (1988). Reinnovation and robust designs: producer and user benefits. Journal of Marketing Management, 3(3), 372-387.

Rungtusanatham, M., Forza, C., Filippini, R., \& Anderson, J. C. (1998). A replication study of a theory of quality management underlying the Deming method: Insights from an Italian context. Journal of Operations Management. 17(1), 77-95. 
Sabet, M. G., \& Klingner, D. (1993). Exploring the impact of professionalism on administrative innovation. Journal of Public Administration Research and Theory, 3(2), 252-266.

Salavou, H., \& Lioukas, S. (2003). Radical product innovations in SMEs: the dominance of entrepreneurial orientation. Creativity and innovation management, 12(2), 94-108.

Samson, D., \& Terziovski, M. (1999). The relationship between total quality management practices and operational performance. Journal of operations management, 17(4), 393409.

Santos-Vijande, M. L., \& Álvarez-González, L. I. (2007). Innovativeness and organizational innovation in total quality oriented firms: the moderating role of market turbulence. Technovation, 27(9), 514-532.

Saraph, J. V., Benson, P. G., \& Schroeder, R. G. (1989). An instrument for measuring the critical factors of quality management. Decision Sciences, 20(4), 810-829.

Schendel, D. (1994). Introduction to competitive organizational behavior: Toward an organizationally-based theory of competitive advantage. Strategic Management Journal, $15(1), 1-4$.

Schmidt, W., \& Finnigan, J. (1992). The Race without a Finish Line: America's Quest for Total Quality. Jossey-Bass, San Francisco, CA.

Scott, S. G., \& Bruce, R. A. (1994). Determinants of Innovative Behavior: A Path Model of Individual Innovation in the Workplace. The Academy of Management Journal, 37(3), 580-607.

Shah, R., \& Goldstein, S. M. (2006). Use of structural equation modeling in operations management research: Looking back and forward. Journal of Operations Management, 24(2), 148-169.

Shea, C., \& Howell, J. (1998). Organizational antecedents to the successful implementation of total quality management. Journal of Quality Management, 3(1), 3-24.

Sila, I. (2007). Examining the effects of contextual factors on TQM and performance through the lens of organizational theories: an empirical study. Journal of Operations Management, 25(1), 83-109.

Sila, I., \& Ebrahimpour, M. (2005). Critical linkages among TQM factors and business results. International Journal of Operations and Production Management, 25(11), 1123-1155.

Singh, P. J., \& Smith, A. (2004). Relationship between TQM and innovation: an empirical study. Journal of Manufacturing Technology Management, 15 (5), 394-401.

Soltani, E., Lai, P. C., Javadeen, S. R. S., \& Gholipour, T. H. (2008). A review of the theory and practice of managing TQM: An integrative framework. Total Quality Management \& Business Excellence, 19(5), 461-479. 
Soltani, E., Lai, P., \& Gharneh, N. S. (2005). Breaking through barriers to TQM effectiveness: lack of commitment of upper-level management. Total Quality Management \& Business Excellence, 16(8), 1009-1021.

Soltani, E., Van Der Meer, R., \& Williams, T. (2004). Challenges posed to performance management by TQM gurus: contributions of individual employees versus systems-level features. Total Quality Management \& Business Excellence, 15(8), 1069-1091.

Souitaris, V. (2002). Technological trajectories as moderators of firm-level determinants of innovation. Research Policy, 31(6), 877-898.

Sousa, R., \& Voss, C. A. (2002). Quality management re-visited: a reflective review and agenda for future research. Journal of Operations Management, 20(1), 91-109.

Spencer, B. A. (1994). Models of organization and total quality management: a comparison and critical evaluation. Academy of Management Review, 19(3), 446-471.

Summers, D. C. S. (2009). Quality management: Creating and sustaining organizational effectiveness. Pearson Prentice Hall, New Jersey.

Teece, D. J. (1980). The diffusion of an administrative innovation. Management Science, 26(5), 464-470.

Teece, D. J. (2000). Managing Intellectual Capital. Oxford, Oxford University Press.

Teece, D. J., Pisano, G., \& Shuen, A. (1997). Dynamic capabilities and strategic management. Strategic Management Journal, 18(7), 509-533.

Terziovski, M., Samson, D., \& Dow, D. (1997). The business value of quality management systems certification. Evidence from Australia and New Zealand. Journal of Operations Management, 15(1), 1-18.

Tushman, M. L., \& O’Reilly III, C. A. (1996). Ambidextrous organizations: Managing evolutionary and revolutionary change. California Management Review, 38(4), 8-30.

Utterback, J. M. (1994), Mastering the Dynamics of Innovation, Harvard Business School Press, Boston, MA.

Valle, S., \& Vázquez-Bustelo, D. (2009). Concurrent engineering performance: Incremental versus radical innovation. International Journal of Production Economics. 119(1), 136148

Venkatraman, N., \& Grant, J. H. (1986). Construct Measurement in Organizational Strategy Research: A Critique and Proposal. Academy of Management Review, 11, 71-87.

Vermaercke, P. (2000). Sense and nonsense of quality assurance in an R\&D environment. Accreditation and Quality Assurance, 5(1), 11-15.

Veryzer, R. W. (1998). Discontinuous innovation and the new product development process. $A n$ international publication of the product development \& management association, 15(4), 304-321. 
Waldman, D. A. (1994). The contributions of total quality management to a theory of work performance. Academy of Management Review, 19(3), 510-536.

Wan, D., Huat, C., \& Lee, F. (2005). Determinants of firm innovation in Singapore. Technovation, 25(3), 261-268.

Weerawardena, J. (2003). The role of marketing capability in innovation based competitive strategy. Journal of Strategic Marketing, 11(1), 15-36.

Yeung, A. C. L., Cheng, T. C. E., \& Lai, K. (2006). An operational and institutional perspective on total quality management. Production and Operations Management, 15(1), 156-170.

Yonghong, Z., Zigang, Z., \& Kaijin, L. (2005). Impact of Technological Innovation on Growth Trajectory of Enterprise's Technological Capability: A Theoretical Analysis. Singapore Management Review, 27(02), 81-101.

Yusuf, Y., Gunasekaran, A., \& Dan, G. (2007). Implementation of TQM in China and organisation performance: an empirical investigation. Total Quality Management \& Business Excellence, 18(5), 509-530.

Zadry, H. R., \& Yusof, S. M. (2006). Total quality management and theory of constraints implementation in Malaysian automotive suppliers: a survey result. Total Quality Management \& Business Excellence, 17(8), 999-1020

Zaho, X., Yeung, A. C. L., \& Lee, T. S. (2004). Quality management and organizational context in selected service industries of China. Journal of Operations Management, 22(6), 575587.

Zeng, S. X., Tian, P., \& Tam, C. M. (2007). Overcoming barriers to sustainable implementation of the ISO 9001 system. Managerial Auditing Journal, 22(3), 244-254.

Zhao, F. (2005). Exploring the synergy between entrepreneurship and innovation. International Journal of Entrepreneurial Behaviour \& Research, 11(1), 25-41.

$\mathrm{Zu}$, X., Fredendall, L. D., \& Douglas, T. J. (2008). The evolving theory of quality management: The role of Six Sigma. Journal of Operations Management, 26(5), 630-650. 


\section{Further Reading}

Aboulnasr, K., Narasimhan, O., Blair, E., \& Chandy, R. (2008). Competitive response to radical product innovations. Journal of Marketing, 72(3), 94-110.

Antoni, M., Nilsson-Witell, L., \& Dahlgaard, J. J. (2005). Inter-project improvement in product development. International Journal of Quality and Reliability Management, 22(8-9), 876-893.

Bagozzi, R. P., Yi, Y., \& Phillips, L. W. (1991). Assessing construct validity in organizational research. Administrative Sciences Quarterly, 36 (3), 421-458.

Bayraktar, E., Tatoglu, E., \& Zaim, S. (2008). An instrument for measuring the critical factors of TQM in Turkish higher education. Total Quality Management \& Business Excellence, 19(6), 551-574.

Benner, M. J., \& Tushman, M. (2002). Process Management and Technological Innovation: A Longitudinal Study of the Photography and Paint Industries. Administrative Science Quarterly, 47(4), 676-709.

Cabrales, A. L., Medina, C. C., Lavado, A. C., \& Cabrera, R. V. (2008). Managing functional diversity, risk taking and incentives for teams to achieve radical innovations. $R \& D$ Management, 38(1), 35-50.

Chang, D., \& Sun, K. (2007). Exploring the Correspondence between Total Quality Management and Peter Senge's Disciplines of a Learning Organization: A Taiwan Perspective. Total Quality Management \& Business Excellence, 18(7), 807-822.

Chen, I. J., \& Paulraj, A. (2004). Towards a theory of supply-chain management: the constructs and measurement. Journal of Operations Management, 22 (2), 119-150.

Chung, Y. C., Tien, S. W., Hsieh, C. H., \& Tsai, C. H. (2008). A study of the business value of Total Quality Management. Total Quality Management \& Business Excellence, 19(4), 367-379.

Coombs, J. E., \& Bierly, P. E. (2006). Measuring technological capability and performance. $R \& D$ Management, 36(4), 421-438.

Coote, L. V., Forrest, E. J., Tam, T. W. (2003). An investigation into commitment in nonWestern industrial marketing relationships. Industrial Marketing Management, 32(7), 595-604.

Crute, V., Ward, Y., Brown, S., \& Graves, A. (2003). Implementing Lean in aerospacechallenging the assumptions and understanding the challenges. Technovation, 23(12), 917-928.

Curkovic, S., Melnyk, S. A., Handfield, R. B., \& Calantone, R. (2000). Investigating the linkage between total quality management and environmentally responsible manufacturing. IEEE Transactions on Engineering Management, 47(4), 444-464. 
Damanpour, F., \& Evan, W. M. (1984). Organizational Innovation and Performance: The Problem of "Organizational Lag". Administrative Science Quarterly, 29(3), 392-409.

Das, A., Handfield, R. B., Calantone, R. J., \& Ghosh, S. (2000). A contingent view of quality management-the impact of international competition on quality. Decision Sciences, 31, 649-690.

Diamantopoulos, A., \& Siguaw, J. A. (2000). Introducing Lisrel: a guide for the uninitiated. SAGE Publications, Ltd.

Dow, D., Samson, D., \& Ford, S. (1999). Exploding the myth: Do all quality management practices contribute to superior quality performance? Production and Operations Management, 8(1), 1-27.

Escanciano, C., Fernández, E., \& Vázquez, C. (2002). Linking the firm's technological status and ISO 9000 certification: results of an empirical research. Technovation, 22(8), 509-515.

Ettlie, J. E. (1997). Quality, technology, and global manufacturing. Production and Operations Management, 6(2), 150-166.

Flor, M., Oltra, M. J., \& del Riu Sec, C. (2005). The influence of firms' technological capabilities on export performance in supplier-dominated industries: the case of ceramic tiles firms. $R \& D$ Management, 35(3), 333-347.

Fuentes, M. M. F., Montes, F. J. L., \& Fernández, L. M. (2006). Total quality management, strategic orientation and organizational performance: the case of Spanish companies. Total Quality Management \& Business Excellence, 17(3), 303-323.

Gopalakrishnan, S., \& Bierly III, P. E. (2006). The impact of firm size and age on knowledge strategies during product development: a study of the drug delivery industry. IEEE Transactions on Engineering Management, 53(1), 3-16.

Gopalakrishnan, S., \& Damanpour, F. (2000). The impact of organizational context on innovation adoption incommercial banks. IEEE Transactions on Engineering Management, 47(1), 14-25.

Green, F. B. (2006). Six-Sigma and the revival of TQM. Total Quality Management \& Business Excellence, 17(10), 1281-1286.

Grewal, R., Cote, J. A., \& Baumgartner, H. (2004). Multicollinearity and Measurement Error in Structural Equation Models: Implications for Theory Testing. Marketing Science, 23(4), 519-529.

Gujarati, D. N., \& Porter, D.C. (2009). Basic Econometrics, 5th edition, NY, McGraw-Hill, Inc.

Hemsworth, D., Sánchez-Rodrig, C., \& Bidgood, B. (2008). A structural model of the impact of Quality Management Practices and purchasing-related Information Systems on purchasing performance: A TQM perspective. Total Quality Management \& Business Excellence, 19(1), 151-164. 
Ho, D. C. K., Duffy, V. G., \& Shih, H. M. (2001). Total quality management: an empirical test for mediation effect. International Journal of Production Research, 39(3), 529-548.

Hsu, S. H., Wang, Y. C., \& Tzeng, S. F. (2007). The Source of Innovation: Boundary Spanner. Total Quality Management \& Business Excellence, 18(10), 1133-1145.

Hung, H. (2007). Influence of the Environment on Innovation Performance of TQM. Total Quality Management \& Business Excellence, 18(7), 715-730.

Hurley, R. F., \& Hult, G. T. M. (1998). Innovation, market orientation, and organizational learning: An integration and empirical examination. Journal of Marketing, 62, $42-54$.

Irani, Z., Beskese, A., \& Love, P. E. D. (2004). Total quality management and corporate culture: constructs of organisational excellence. Technovation, 24(8), 643-650.

Issac, G., Rajendran, C., \& Anantharaman, R. N. (2004). A conceptual framework for total quality management in software organizations. Total Quality Management \& Business Excellence, 15(3), 307-344.

Jansen, J. J. P., Vera, D., \& Crossan, M. (2009). Strategic leadership for exploration and exploitation: The moderating role of environmental dynamism. The Leadership Quarterly. 20(1), 5-18.

Ju, T. L., Lin, B., Lin, C., \& Kuo, H. (2006). TQM critical factors and KM value chain activities. Total Quality Management \& Business Excellence, 17(3), 373-393.

Jun, M., Cai, S., \& Peterson, R. T. (2004). Obstacles to TQM Implementation in Mexico's Maquiladora Industry. Total Quality Management \& Business Excellence, 15(1), 59-72.

Jung, J. Y., \& Wang, Y. J. (2006). Relationship between total quality management (TQM) and continuous improvement of international project management (CIIPM). Technovation, 26(5-6), 716-722.

Kale, S., \& Arditi, D. (2006). Diffusion of ISO 9000 certification in the precast concrete industry, Construction Management and Economics, 24, 485-495.

Koc, E. (2006). Total quality management and business excellence in services: The implications of all-inclusive pricing system on internal and external customer satisfaction in the Turkish tourism market. Total Quality Management \& Business Excellence, 17(7), 857877.

Kumar, V., \& Boyle, T. (2001). A quality management implementation framework for manufacturing-based R\&D environments. International Journal of Quality and Reliability Management, 18(2/3), 336-359.

Lagrosen, Y., \& Lagrosen, S. (2005). The effects of quality management-a survey of Swedish quality professionals. International Journal of Operations and Production Management, 25(10), 940 . 
Lee, M., \& Na, D. (1994). Determinants of technical success in product development when innovative radicalness is considered. An International Publication of the Product Development \& Management Association, 11(1), 62-68.

Lewin, A. Y., Long, C. P., \& Carroll, T. N. (1999). The coevolution of new organizational forms. Organization Science, 10(5), 535-550.

Lien, Y. (2007). Organizational process alignment and dynamic capabilities in high-tech industry. Total Quality Management \& Business Excellence, 18(9), 1023-1034.

Lin, B. W., \& Chen, J. S. (2005). Corporate technology portfolios and R\&D performance measures: a study of technology intensive firms. $R \& D$ Management, 35(2), 157-170.

Lin, L. H., \& Lu, I. Y. (2006). Product quality as a determinant of product innovation: an empirical analysis of the global automotive industry. Total Quality Management \& Business Excellence, 17(2), 141-147.

Linderman, K., Schroeder, R. G., Zaheer, S., Liedtke, C., \& Choo, A. S. (2004). Integrating quality management practices with knowledge creation processes. Journal of Operations Management, 22(6), 589-607.

Llore'ns Montes, F. J., Ruiz Moreno, A., \& Garcia Morales, V. (2005). Influence of support leadership and teamwork cohesion on organizational learning, innovation and performance: an empirical examination. Technovation, 25(10), 1159-1172.

Longbottom, D., Osseo-Asare, A. E., Chourides, P., \& Murphy, W. D. (2006). Real quality: does the future of TQM depend on internal marketing? Total Quality Management \& Business Excellence, 17(6), 709-732.

Mann, R. (2008). Revisiting a TQM research project: The quality improvement activities of TQM. Total Quality Management \& Business Excellence, 19(7), 751-761.

Mansfield, E. (1963). The Speed of Response of Firms to New Techniques. Quarterly Journal of Economics, 11 (May). 290-311.

Marsh, H. W., \& Hocevar, D. (1988). A new, more powerful approach to multitrait multimethod analysis: application of second-order confirmatory factor analysis. Journal of Applied Psychology, 73 (1), 107-117.

Martin, M., \& Jimenez-Jimenez, D. (2008). Are companies that implement TQM better learning organisations? An empirical study. Total Quality Management \& Business Excellence, 19(11), 1101-1115.

McAdam, R., \& Bannister, A. (2001). Business performance measurement and change management within a TQM framework. International Journal of Operations and Production Management, 21(1/2), 88-107.

Mcadam, R., \& Leonard, D. (2005). A TQM dynamics perspective on Baldrige and business excellence model comparisons. Total Quality Management \& Business Excellence, 16(6), 771-791. 
McFarlin, D. B., \& Sweeney, P. D. (1992). Distributive and procedural justice as predictors of satisfaction with personal and organizational outcomes. Academy of Management Journal, 35(3), 626-637.

Molina, L. M., Lloréns-Montes, J., \& Ruiz-Moreno, A. (2007). Relationship between quality management practices and knowledge transfer. Journal of Operations Management, 25(3), 682-701.

Naveh, E. (2007). Formality and discretion in successful R\&D projects. Journal of Operations Management, 25(1), 110-125.

Özsomer, A., \& Gençtürk, E. (2003). A resource-based model of market learning in the subsidiary: The capabilities of exploration and exploitation. Journal of International Marketing, 11(3), 1-29.

Oztas, A. (2004). Current Status of Total Quality Management Implementation in the Turkish Cement Industry/A. Oztas, E. Ozbay, A. Yeginobali. Total Quality Management, 15(7), 985-999.

Öztas, A., Özbay, E., \& YeGinobali, A. (2004). Current Status of Total Quality Management Implementation in the Turkish Cement Industry. Total Quality Management \& Business Excellence, 15(7), 985-999.

Prajogo, D. I., \& McDermott, C. M. (2005). The relationship between total quality management practices and organizational culture. International Journal of Operations and Production Management, 25(11), 1101-1122.

Prajogo, D. I., McDermott, P., \& Goh, M. (2008). Impact of value chain activities on quality and innovation. International Journal of Operations \& Production Management, 28(7), 615635 .

Psychogios, A. G., Wilkinson, A., \& Szamosi, L. T. (2009). Getting to the heart of the debate: TQM and middle manager autonomy. Total Quality Management \& Business Excellence, 20(4), 445-466.

Quintana-García, C., \& Benavides-Velasco, C. A. (2008). Innovative competence, exploration and exploitation: The influence of technological diversification. Research Policy, 37(3), 492-507.

Reed, R., Lemak, D. J., \& Montgomery, J. C. (1996). Beyond process: TQM content and firm performance. Academy of Management Review, 21(1), 173-202.

Salman, N., \& Saives, A. L. (2005). Indirect networks: an intangible resource for biotechnology innovation. R\&D Management, 35(2), 203-215.

Samli, C. (2007). Achieving power in adverse modern markets: the drive to innovate. The Marketing Review, 7(2), 155-170.

Schmickl, C., \& Kieser, A. (2008). How much do specialists have to learn from each other when they jointly develop radical product innovations? Research Policy, 37(3), 473-491. 
Schriesheim, C. A. (1979). The Similarity of Individual Directed and Group Directed Leader Behavior Descriptions. The Academy of Management Journal, 22(2), 345-355.

Seo, D., Torabi, M R., Blair, E. H., \& Ellis, N. T. (2004). A cross-validation of safety climate scale using confirmatory factor analytic approach. Journal of Safety Research, 35(), 427445

Seth, D., \& Tripathi, D. (2006). A critical study of TQM and TPM approaches on business performance of Indian manufacturing industry. Total Quality Management \& Business Excellence, 17(7), 811-824.

Shah, R., \& Ward, P.T. (2003). Lean manufacturing: context, practice bundles, and performance. Journal of Operations Management, 21(2), 129-149.

Soltani, E. (2005). Top management: A threat or an opportunity to TQM? Total Quality Management \& Business Excellence, 16(4), 463-476.

Sousa, R. (2003). Linking quality management to manufacturing strategy: an empirical investigation of customer focus practices. Journal of Operations Management, 21(1), 118.

Sousa, R., \& Voss, C. A. (2001). Quality management: Universal or context dependent. Production and Operations Management, 10 (4), 383-404.

Sousa, R., \& Voss, C. A. (2008). Contingency research in operations management practices. Journal of Operations Management, 26 (6), 697-713.

Stevens, J. P. (2002). Applied multivariate statistics for the social sciences. Lawrence Erlbaum Associates, Mahwah, NJ.

Taylor, J., \& McAdam, R. (2004). Innovation adoption and implementation in organizations: a review and critique. Journal of General Management, 30(1), 17-38.

Tu, Q., Vonderembse, M. A., \& Ragu-Nathan, T. S. (2001). The impact of time-based manufacturing practices on mass customization and value to customer. Journal of Operations Management, 19, 201-217.

Tushman, M. L. (2004). From engineering management/R\&D management, to the management of innovation, to exploiting and exploring over value nets: 50 years of research initiated by the IEEE-TEM. IEEE Transactions on Engineering Management, 51(4), 409-411.

Warwood, S., \& Roberts, P. (2004). A survey of TQM success factors in the UK. Total Quality Management \& Business Excellence, 15(8), 1109-1117.

Williams, F. P., D'Souza, D. E., Rosenfeldt, M. E., Kassoud, K. (1995). Manufacturing strategy, business strategy and firm performance in a mature industry. Journal of Operations Management, 13(1), 19-33. 
Wincent, J., Anokhin, S., \& Boter, H. (2009). Network board continuity and effectiveness of open innovation in Swedish strategic small-firm networks. $R \& D$ Management, 39(1), 5567.

Wu, C. W., \& Chen, C. L. (2006). An integrated structural model toward successful continuous improvement activity. Technovation, 26(5-6), 697-707.

Wu, H. L., Lin, B. W., Chen, C. J., \& China, T. (2007). Contingency view on technological differentiation and firm performance: evidence in an economic downturn. $R \& D$ Management, 37(1), 75-88.

Yam, R. C. M., Tam, A. Y. K., Tang, E. P. Y., \& Mok, C. K. (2005). TQM: A change management model for market orientation. Total Quality Management \& Business Excellence, 16(4), 439-461.

$\mathrm{Zu}, \mathrm{X}$. (2009). Infrastructure and core quality management practices: how do they affect quality? International Journal of Quality \& Reliability Management, 26(2), 129-149. 